\title{
TRANSMUTATION OF WASTE ACTINIDES IN THERMAL REACTORS: \\ SURVEY CALCULATIONS OF CANDIDATE IRRADIATION SCHEMES
}

T. C. GORRELL

\author{
TIS FILE \\ RECORD COPY
}

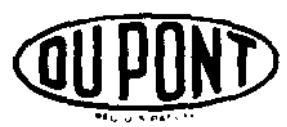

SAVANNAH RIVER LABORATORY AIKEN, SOUTH CAROLINA 29801 


\section{NOTICE}

This report was prepared as an account of work sponsored by the United States Government. Neither the United States nor the United States Department of Enerty, nor any of their contractors, subcontractors, or their employees, makes any waranty, express or implied or assumes any legal liability of respontibltity for the accuracy, completeness or usefulness of any information, apparatus, product or process disctosed, or represents that its use would not infringe privately owned rights.

Printed In the United States of Amorice

Avelleble tram

National Technical Information Service

U.S. Depertment of Commerce

s20s Port hoval Rosd

Springfleld, Virginis 22181

Price: Printed Copy $\$ 4.00$; Microtiche $\$ 3.00$ 


\section{TRANSMUTATION OF WASTE ACTINIDES}

\section{IN THERMAL REACTORS:}

SURVEY CALCULATIONS OF

CANDIDATE IRRADIATION SCHEMES

by

T. C. Gorrell

Approved by

J. D. Spencer, Research Manager

Reactor Physics Division

Publication Date: November 1978

\section{E. I. DU PONT DE NEMOURS AND COMPANY SAVANNAH RIVER LABORATORY AIKEN, SOUTH CAROLINA 29801}

PRePaRed for the U. S. DePARTMENT OF ENERGy UNDER CONTRACT AT(07-2)-1 


\section{ABSTRACT}

Actinide recycle and transmutation calculations were made for twelve specific thermal reactor environments. The calculations included $\mathrm{H}_{2} \mathrm{O}$-moderated reactor lattices with enriched $U$, recycled $\mathrm{Pu}$, and $233,235 \mathrm{U}-\mathrm{Th}$. In addition two $\mathrm{D}_{2} \mathrm{O}$ reactor cases were calculated.

When all actinides were recycled into ${ }^{235} \mathrm{U}$-enriched fuel, about $10 \%$ of the transuranic actinides were fissioned per 3-year fuel cycle. About $9 \%$ of the actinides were fissioned per 3-year fuel cycle when waste actinides (no $\mathrm{U}$ or $\mathrm{Pu}$ ) were irradiated in separate target rods in a U-fuel assembly. When actinides were recycled in separate target assemblies, the fission rate was strongly dependent on the specific loading of the target. Fission rates of 5 to $10 \%$ per 3 -year fuel cycle were observed. 


\section{Introduction}

Surmary

Background

Description of Computational Method

Verification of LWR Calculations

H. B. Robins on Fue1

Yankee Fuel

Description of Actinide Recycle Alternatives

Actinides from LWR Fuel - U Diluent (Group 1)

Case 1.1

Case 1.2

Case 1.3

Case $1: 4$

Comparison of Cases in Group 1

Actinides from LWR Fuel - Zirconium Diluent (Group 2)

Case 2.1

Case 2.2

Case 2.3

Comparison of Cases in Group 2

Actinides from Advanced-Charge Design (Group 3)

Case 3.1

Case 3.2

Case 3.3 
CONTENTS, Contd.

Actinides Irradiated in $\mathrm{D}_{2} \mathrm{O}$ Reactors (Group 4)

Case 4.1

Case 4.2

Future Study

Appendix A - Tables of Actinide Contents

References 
Table A.1 Beginning and Ending Actinide Content of Base-Case LWR Fue 1

Table A.2 Waste Actinides From Each LWR U-Assembly Recycled Into New Assembly - Case 1.1

Table A.3 A1I Actinides From Each LWR U-Assembly Recycled Into New Assembly With Variable U-235 - Case 1.2

Table A.4 Al1 Actinides (Except U) From 5 LWR U-Assemblies Recycled Into 1 Assembly of Natural U - Case 1.3

Table A.5 Waste Actinides From 20 LWR U-Fuel Rods Recycled Into 1 Target Rod of Depleted U - Case 1,4

Table A.6 Waste Actinides From 100 LWR U-Fuel Rods Recycled Into I Target Rod of Zirconium - Case 2.1

Table A.7 Waste Actinides From 50 LWR U-Fuel Rods Recycled Into I Target Rod of Zirconium - Case 2.2

Table A.8 Waste Actinides From 50 LWR U-Fuel Rods Irradiated For 10 Consecutive Fuel Cycles - Case 2.3

Table A.9 Beginning And Ending Actinide Content of Mixed U/Pu Fue1

Table A.10 Comparison Of Waste Actinides Generated In 3 Fue1 Types

Table A.11 Waste Actinide Content of Target Assembly In U/Pu Lattice - Case 3.1

Table A.12 Waste Actinide Content of Target Assembly In U/Pu Lattice - Case 3.2

Table A.13 Waste Actinides From Th Assembly Enriched In U-233 And U-235 Recycled Into 1 New Assembly - Case 3.3

Table A.14 Waste Actinides From 100 LWR U-Fuel Rods Recycled Into Target In SRP Lattice - Case 4.1

Table A.15 Beginning And Ending Contents of Two CANDU Fuel Types

Table A.16 Waste Actinides From Each CANDU U/Pu Assemb1y Recycled Into New Assembly - Case 4.2 
1 GLASS Input Parameters

2 Comparison of Calculated and Measured Actinide Contents H. B. Robinson Fue1

\section{LIST OF FIGURES}

1 Examples of LWR Fuel Supercells

2. Yankee-Rowe Fue1, Uranium Contents vs Exposure

3 Yankee-Rowe Fue1, Total Plutonium Contents vs Exposure

4 Yankee-Rowe Fuel, Plutonium Assay vs Exposure

5 Yankee-Rowe Fue1, Other Actinide Contents vs Exposure

6 Flow Diagrams of Actinide Recycle - Four U Diluent Cases

7 Flow Diagrams of Actinide Recycle - Three Zr Diluent Cases

8 Flow Diagrams of Actinide Recycle - Two Advanced Charge Designs

9 Flow Diagrams of Actinide Recycle - Two $\mathrm{D}_{2} \mathrm{O}$ Reactor Cases

10 Waste Actinides from each LWR U-Assembly Recycled into New Assembly - Case 1.1

11 Al1 Actinides from each LWR U-Assembly Recycled into New As sembly with Variable $235 \mathrm{U}$ - Gaso-1.Z-

12 Waste Actinides from 20 LWR U-Fuel Rods Recycled into One Target Rod of Depleted U - Case 1.4

13 Waste Actinides from 50 LWR U-Fuel Rods Recycled into One Target Rod of Zirconium - Case 2.2

14 Waste Actinides from 50 LWR U-Fuel Rods Irradiated for Ten Consecutive Fue1 Cycles - Case 2.3

15 Waste Actinide Content of Light Target Assembly in U/Pu Lattice - Case 3.1 
16 Waste Actinide Content of Heavy Target Assembly in U/Pu Lattice - Case 3.2

17 Waste Actinides from 100 LWR U-Fuel Rods Recycled into Target in SRL Lattice - Case 4.1

18 CANDU-Pickering Assembly

19 Waste Actinides from each CANDU U/Pu Assembly Recycled into New Assembly - Case 4.2 
TRANSMUTATION OF WASTE ACTINIDES IN THERMAL REACTORS: SURVEY CALCULATIONS OF CANDIDATE IRRADIATION SCHEMES

\section{INTRODUCTION}

Partitioning the actinides in fuel wastes from light water reactors (LWR) and transmuting them to fission products in power reactors represents a waste management concept which could reduce the long-term risk associated with geologic isolation of the wastes. The Chemical Technology Division of Oak Ridge National Laboratory (ORNL) is coordinating a program* involving several national laboratories to evaluate the feasibility and incentives that may exist for implementing the concept. Studies and tests pertaining to chemical partitioning of the actinides are being conducted at other sites, and are not discussed in this report. The portion of the process considered in the Savannah River Laboratory (SRL) study pertains to neutron-induced transmutation in thermal reactors. Specifically, computations were made to assess methods in which the waste actinides would be recycled and re-irradiated in various fuel or target forms. The transmutation results described in this report were obtained from survey studies of several recycle options; two of the more promising options were chosen for more detailed study, and these will be described in a later document.

* Contract No. W-7405-eng-26. 
Actinide recycle calculations were made for twelve specific situations. The calculations included $\mathrm{H}_{2} \mathrm{O}$ moderated reactor lattices with enriched $\mathrm{U}$, recycled $\mathrm{Pu}$, and $233,235 \mathrm{U}-\mathrm{Th}$. In addition two $\mathrm{D}_{2} \mathrm{O}$ reactor cases were calculated. Detailed results and plots of actinide transmutation rates are given in Tables A.1A.16 in Appendix A and Figures 10-19, respectively.

When all actinides were recycled into ${ }^{235} \mathrm{U}$-enriched fuel, about $10 \%$ of the transuranic actinides were fissioned per 3-year fuel cycle. After five recycles, none of the actinide concentrations had equilibrated, and the higher isotopes of $\mathrm{Cm}$ and $\mathrm{Cf}$ were increasing rapidly. In this recycle mode the $\mathrm{Pu}$ isotopes were always diluted by $U$ and would be difficult to recover for weapons production.

About $9 \%$ of the actinides were fissioned per 3-year fuel cycle when waste actinides, excluding $\mathrm{U}$ and $\mathrm{Pu}$, were irradiated in separate target rods in a U-fuel assembly. Zirconium or some other inert diluent material must be used to limit the target rod power. The diluent may introduce difficulties in chemical recovery operations on the target.

When actinides were recycled in separate target assemblies, the fission rate was strongly dependent on the specific loading of the target. Fission rates of 5 to $10 \%$ per 3 -year fuel cycle were obtained in the cases studied.

Entire target assemblies are easier to handle and make a more attractive recycle mode than separate target rods in a fuel assembly. An assembly containing both target rods and fuel rods would require dismantling after irradiation, before reprocessing, if the target and fuel process streams are to be kcpt separate. However; the complete target assembly móde would not require any special disassembly. 


\section{BACKGROUND}

The Chemical Technology Division of ORNL is coordinating a program to analyze Partitioning-Transmutation $(\mathrm{P}-\mathrm{T})$ as a waste management concept for the nuclear fuel cycle.'

- Partitioning is defined as the chemical process in which the level of actinides in radioactive waste is reduced to a greater extent than dictated by normal economic consideration, and where effective recovery of the actinides is achieved.

- Transmutation is defined as the irradiation process in which the actinides are converted to fission products in a reactor.

Information required to calculate the risks, costs and benefits of the P-T concept is being developed at several national laboratories under ORNL supervision. Earlier work done at other sites had little central coordination and treated some aspects of the concept incompletely. The ultimate objective of the present overall evaluation is to place the many ramifications of P-T on a common basis and to determine if implementation is feasible and cost-effective.

The responsibility of SRL was to study neutron-induced transmutation in thermal reactors. State-of-the-art computer programs such as the GLASS code ${ }^{2}$ were utilized. These computer programs have routinely obtained good results for reactivity and depletion calculations for $\mathrm{D}_{2} \mathrm{O}$ systems. ${ }^{3}$ The objective of this portion of the study was to make survey calculations for several actinide recycle alternatives. The more promising cases are to be examined in greater detail in subsequent studies.

This report contains a brief description of the GLASS code, the results of verification calculations for LWR fuel with measured actinide content, and the results of calculations in which actinides were recycled in various fuel or target forms. Actinide production and depletion are described for twelve specific cases, which include a variety of possible irradiation sequences. Because waste actinide recycle is not expected to cause a major perturbation in the neutron economy of an LWR lattice, detailed neutron balance representations were not prepared for the full reactor lattices. 
DESCRIPTION OF COMPUTATIONAL METHOD

The SRL GLASS code was used for all neutronic and depletion calculations in this study. GLASS performs the following general operations :

- A basic lattice physics calculation with multigroup integral transport methods. Options include 37 or 84 energy groups.

- A Nordheim calculation of self-shielded resonance integrals.

- An isotope depletion and decay calculation for a1l actinides and for selected fission products that is based on reaction rates from the physics calculation. The neutron energy spectrum calculation is repeated at regular intervals during the depletion calculation.

Input parameters include isotopic compositions, temperatures, and spatial dimensions in annular, square, or hexagonal geometry. A standard cross section data base is part of the SRL library, which is regularly updated to provide good results for thermal and near-thermal reactors; it currently includes the Phase I ENDF/B-V data for the transplutonium actinides.

GLASS is not limited to the simple "pin cell" geometry, with zero-current boundary conditions. It may be used to simulate multi-region annular geometry within a cell, and different cells may be linked to form "supercells". A supercell is defined as a connected group of cells which form an array which repeats by translation in a lattice. The neutron currents at cell boundaries are not zero, but the total neutron current around the supercell normally is zero.

Examples of supercells are shown in Figure 1. Figure 1-a is a target rod surrounded by eight fuel rods to form a repeating. array (e.g., within an Lin fuei assembIy). In Figure $\overline{1}-\bar{b}$ entire LWR fuel or target assemblies have been represented by annular mockups. These assemblies may have different properties. This feature is important because it permits a realistic calculation of resonance self-shielding in target assemblies while also obtaining a realistic multigroup spectrum that is dominated by the fuel environment. 

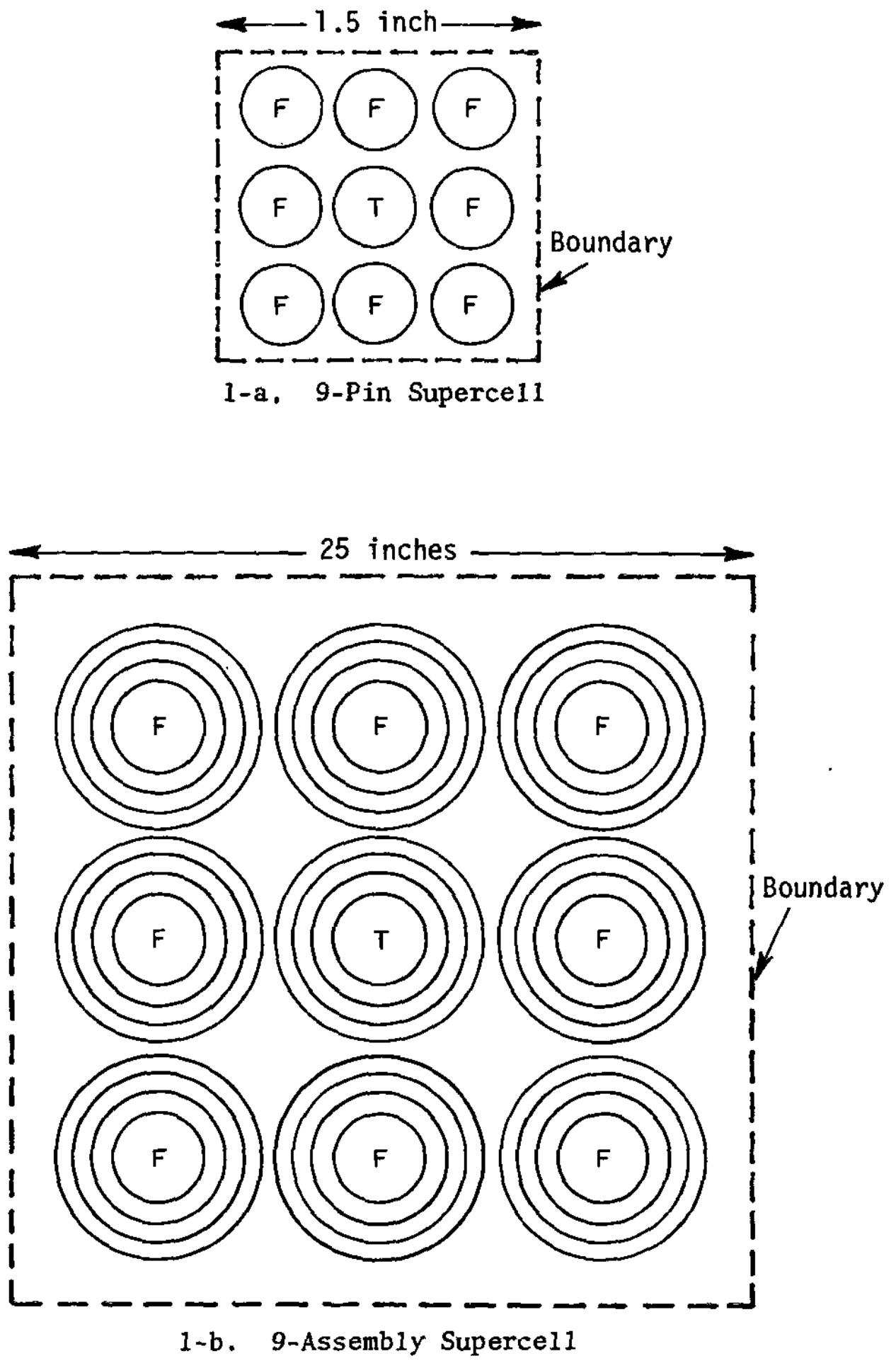

FIGURE 1. Examples of LWR Fuel Supercells 


\section{VERIFICATION OF LWR CALCULATIONS}

To verify that the GLASS code is appropriate for use in LWR systems, comparisons were made between calculated and measured actinide contents of $H$. B. Robinson and Yankee fuel pins. These fuel pins wexe assumed to be in regions of asymptotic flux. Total fissions and total exposure ${ }^{4}$ were deduced from measured ${ }^{148} \mathrm{Nd}$ contents. A unit cell consisted of $\mathrm{H}_{2} \mathrm{O}$ moderator, cladding, and a fuel rod. The standard SRL multigroup (84) cross section set was used, with one exception. A $13 \%$ reduction was made in the neutron width and capture width of the ${ }^{238} \mathrm{U}$ resonance at $6.7 \mathrm{ev}$ to achieve better agreement between calculated and measured $\mathrm{Pu}$ contents.

\section{H. B. Robinson Fuel}

Input parameters were derived from cell geometries and operating conditions of the H. B. Robinson reactor (Table 1 ). The cell pitch used was 5\% larger than the "true" pitch to mock up $\mathrm{H}_{2} \mathrm{O}$ in empty pin positions in the fuel bundle.

The results of the calculations are shown in Table 2 for two exposures. The most interesting parameters are the ${ }^{235} \mathrm{U}$, ${ }^{236} \mathrm{U}$, and ${ }^{239} \mathrm{Pu}$ isotopic fractions and the ratio of ${ }^{239} \mathrm{Pu}$ to ${ }^{2{ }^{8}} \mathrm{U}$. The agreement between calculated and measured ${ }^{5}$ values for these parameters is good at both exposures. ${ }^{235} \mathrm{U}$ depletion calculated by GLASS is somewhat more than measured, but the ${ }^{236} \mathrm{U}$ values are in very good agreement. ${ }^{239} \mathrm{Pu}$ production calculated by GLASS is somewhat higher than measured, but the ratios of ${ }^{239} \mathrm{Pu}$ to total $\mathrm{Pu}$ are in good agreement.

\section{Yankee Fuel}

GLASS calculations were performed for Yankee fuel having an initial ${ }^{235} \mathrm{U}$ enrichment of $3.4 \%$. Input parameters are given in Table 1. Reference 6 presents measured results of content versus exposure for an extensive core evaluation program in which more than 100 individual fuel pins were analyzed. Also, additional analyses were made at Pacific Northwest Laboratory (PNL), described in Reference 7. Comparisons of calculated and measured results are given in Figures 2-5. Reference 6 results are shown as a smooth curve drawn through the 100 data points. 


\section{TABLE 1}

\section{GLASS Input Parameters}

\begin{tabular}{|c|c|c|c|}
\hline \multirow[b]{2}{*}{ Parcometer } & \multicolumn{2}{|c|}{ Reactor } & \multirow[b]{2}{*}{$\begin{array}{l}\text { STANDARD } \\
\text { LWR FUEL }\end{array}$} \\
\hline & 1. B. ROBINSON & YANKEE-ROWE & \\
\hline Pin Array (square) & $15 \times 15$ & $6 \times 6$ & $17 \times 17$ \\
\hline Number empty positions & 21 & 0 & 25 \\
\hline True pitch, in. & .563 & .422 & .496 \\
\hline Effective pitch, in. & .591 & .422 & .519 \\
\hline Fuel pellet $O D$ (hot), in. & .371 & .298 & .325 \\
\hline Clad OD (hot), in. & .420 & .340 & .370 \\
\hline Clad material & Zircaloy & Stainless & Zircaloy \\
\hline $\begin{array}{l}\text { Density of } \mathrm{UO}_{2} \text { (hot) } \\
\mathrm{g} / \mathrm{cm}^{3}\end{array}$ & 10.16 & 10.16 & 10.16 \\
\hline $\mathrm{U}_{\mathrm{o}}$ metal, ${ }^{\alpha} \mathrm{g} / \mathrm{ft}$ & 190,3 & 122.8 & 145.8 \\
\hline $\begin{array}{l}235 \mathrm{U} \text { enrichment, \% } \\
\text { Moderator }\left(\mathrm{H}_{2} \mathrm{O}\right)\end{array}$ & 2.56 & 3.40 & 3.20 \\
\hline Temperature, ${ }^{\circ} \mathrm{C}$ & 300 & 268 & 309 \\
\hline Density, $\mathrm{g} / \mathrm{cm}^{3}$ & .713 & .769 & .693 \\
\hline Natural boron, ppm & 450 & none & 500 \\
\hline Specific Exposure & & & \\
\hline $\mathrm{MWD} / \mathrm{MTM}$ & 31,000 & $25,000^{b} \quad 15,000^{c}$ & 33,000 \\
\hline $\mathrm{MWD} / \mathrm{ft}$ & 5.90 & 1.84 & 4.81 \\
\hline Irradiation Time, Days & 1100 & 930 & 1100 \\
\hline
\end{tabular}

a. $\mathrm{U}_{\mathrm{o}}$ metal is the initial uranium content. $b, c$. Two irradiation intervals. 
TABLE 2

Comparison of Calculated and Measured

Actinide Contents - H. B. Robinson Fuel

\begin{tabular}{|c|c|c|c|c|c|}
\hline \multirow{2}{*}{ Parameter } & \multirow[b]{2}{*}{ Nuclide } & \multirow{2}{*}{ Exp $=24,570$} & \multirow{2}{*}{$\frac{\text { MWD/MIM }}{\text { Neas }}$} & \multirow{2}{*}{$\frac{E x p=30,920}{\text { Calc }}$} & \multirow{2}{*}{$\frac{M W D / M T M}{\text { Meas }}$} \\
\hline & & & & & \\
\hline \multirow{4}{*}{$\begin{array}{l}\text { U Isotopic } \\
\text { (atom } \%)\end{array}$} & 234 & .02 & .02 & .02 & .01 \\
\hline & $235^{a}$ & .80 & .82 & .56 & .61 \\
\hline & 236 & .32 & .33 & .35 & .35 \\
\hline & 238 & 98.86 & 98.83 & 99.07 & 99.03 \\
\hline \multirow{5}{*}{$\begin{array}{l}\text { Pu Isotopic } \\
\text { (atom \%) }\end{array}$} & 238 & 1.02 & 1.13 & 1.52 & 1.66 \\
\hline & 239 & 58.91 & 59.09 & 53.61 & 53.79 \\
\hline & 240 & 23.78 & 23.11 & 25.49 & 24.89 \\
\hline & 241 & 11.90 & 12.53 & 12.97 & 13.75 \\
\hline & 242 & 4.39 & 4.14 & 6.41 & 5.91 \\
\hline $239 \mathrm{Pu} /{ }^{238} \mathrm{U}$ & & .00508 & .00494 & .00529 & .00518 \\
\hline
\end{tabular}

a. Initial $235 \mathrm{U}=2.56 \%$ 


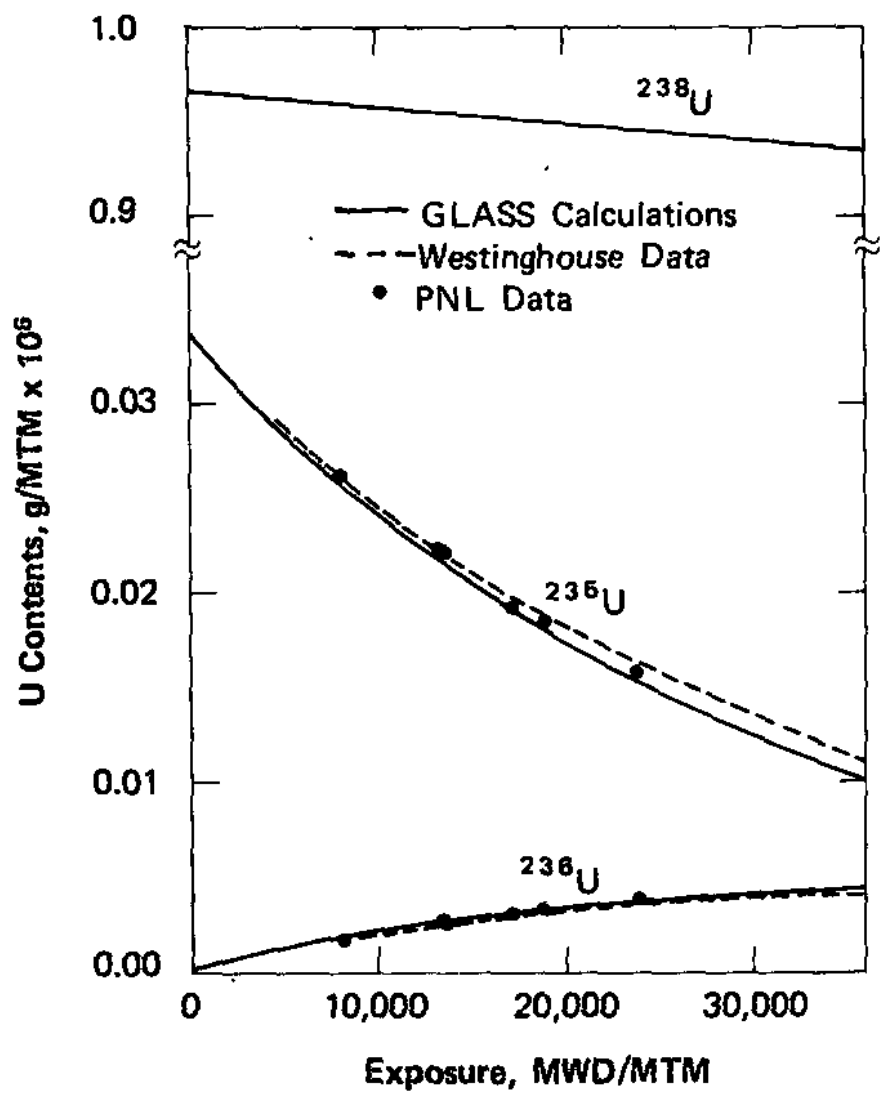

FIGURE 2. Yankee-Rowe Fuel, Uranium Contents vs Exposure.

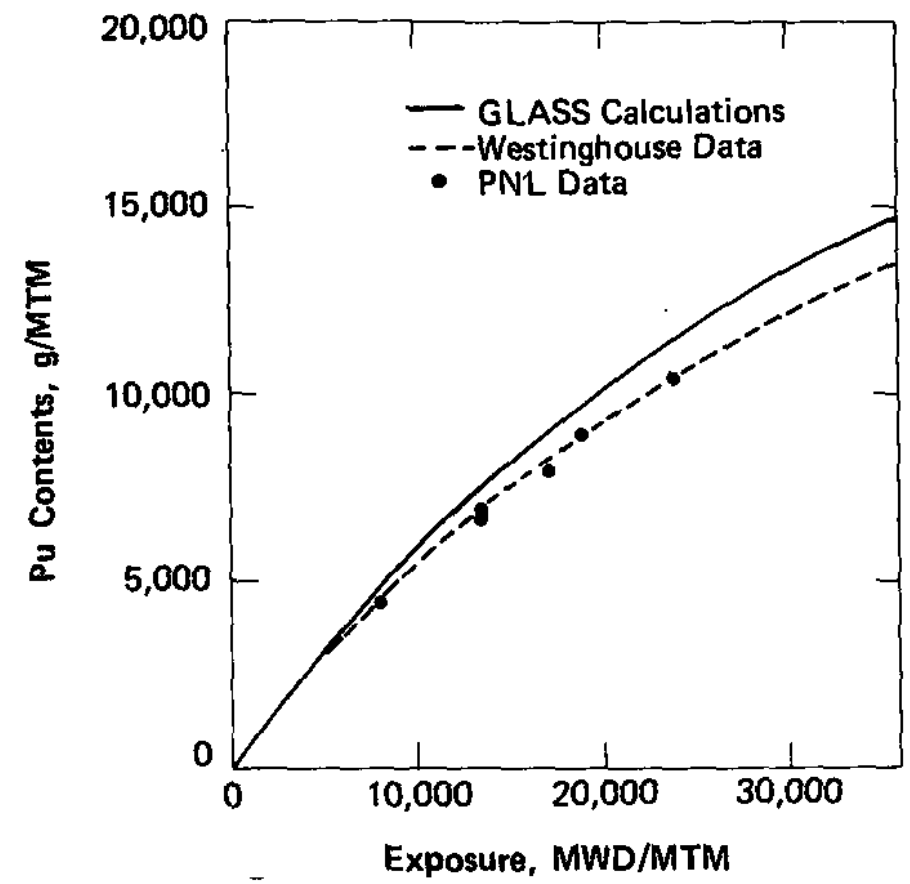

FIGURE 3. Yankee-Rowe Fuel, Total Plutonium Contents vs Exposure 


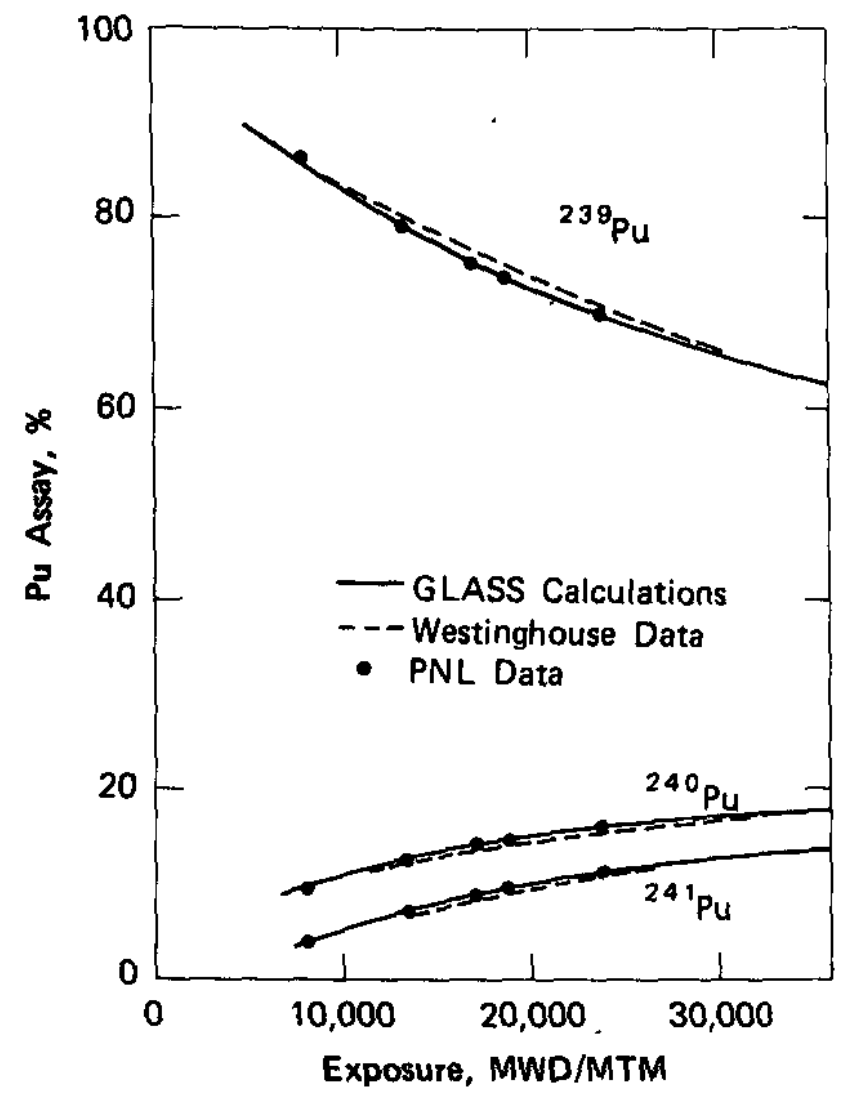

FIGURE 4. Yankee-Rowe Fuel, Plutonium Assay vs Exposure

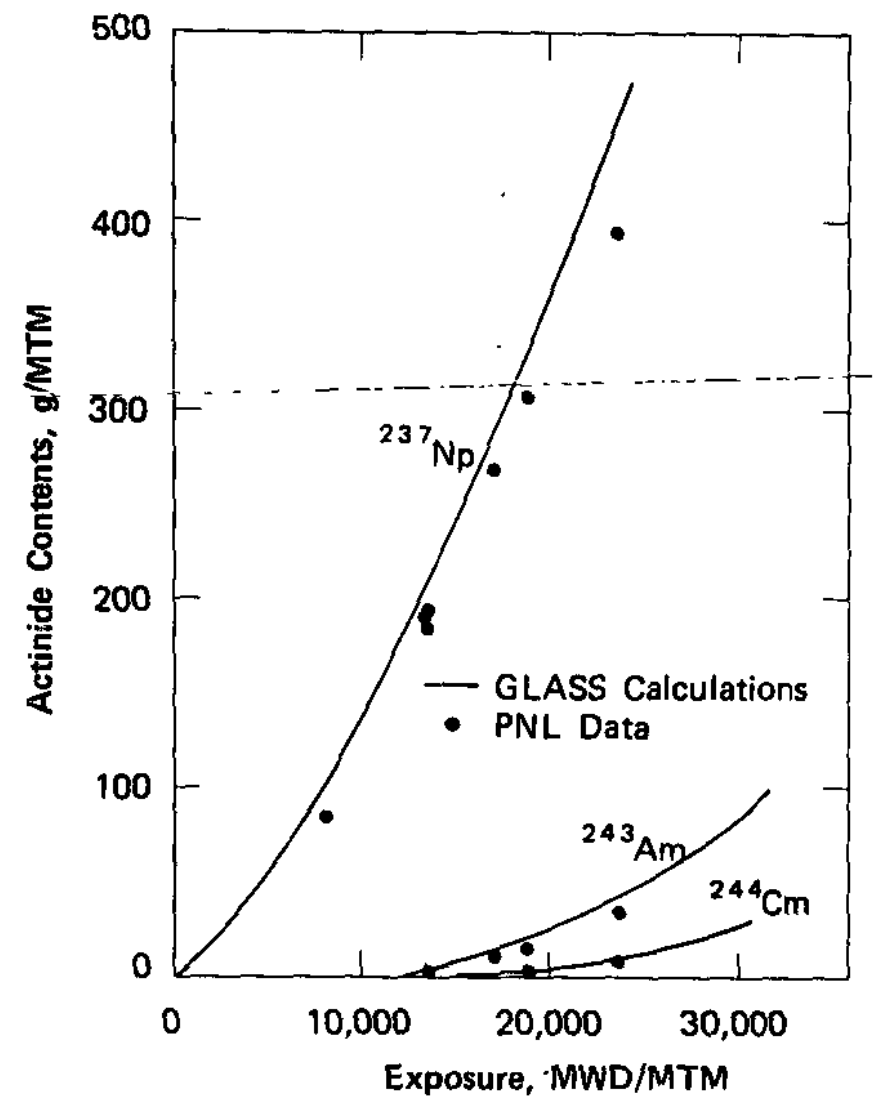

FIGURE 5. Yankee-Rowe Fue1, Other Actinide Contents vs Exposure 
${ }^{23} \mathrm{U}$ depletion, calculated by GLASS, is somewhat more than measured, but the ${ }^{236} \mathrm{U}$ contents agree (Figure 2). The calculated total Pu content (Figure 3 ) is about $8 \%$ greater than measured. However, the calculated $\mathrm{Pu}$ isotopic ratios (Figure 4) agree well with measurements. Figure 5 shows results for ${ }^{237} \mathrm{~Np},{ }^{243} \mathrm{Am}$, and $244 \mathrm{Cm}$ for a few measured data points. Calculated values are about $10 \%$ higher than measured.

The stainless steel cladding of the Yankee fuel had a very marked effect on the neutron spectrum and the transuranium production rates. In calculations in which Zircaloy was substituted for steel cladding, the transuranium contents were reduced 8 to $10 \%$ at any given exposure. All other fuel types in this study were clad with Zircaloy.

\section{DESCRIPTION OF ACTINIDE RECYCLE ALTERNATIVES}

The actinide recycle options were divided into four general groups with additional sub-division within the groups. The terms "waste actinides" and "all actinides" are used. "All actinides" includes the complete 1ist of actinides through ${ }^{252} \mathrm{Cf}$. "Waste actinides" does not include $\mathrm{U}$ or $\mathrm{Pu}$. An outline of the various cases follows:

Group 1 - Uranium used as diluent (Figure 6)

Case 1.1 - Waste actinides from each LWR U-assembly recycled into new assembly.

Case 1.2 - All actinides from each LWR U-assembly recycled into assembly with variable ${ }^{235} \mathrm{U}$.

Case 1.3 - All actinides (except U) from five LWR $\mathrm{U}$-assemblies recycled into one assembly of naturaI $U$.

Case 1.4 - Waste actinides from twenty LWR fuel rods recycled into one target rod of depleted $U$.

Group 2 - Zirconium used as diluent; separate target rods charged to LWR fuel assembly (Figure 7)

Case 2.1 - Waste actinides from 100 LWR U-fuel rods recycled into one target rod.

Case 2.2 - Waste actinides from 50 LWR U-fuel rods recycled into one target rod. 
1.1 Waste actinides from each LWR U-assembiy recycled into new assembiy

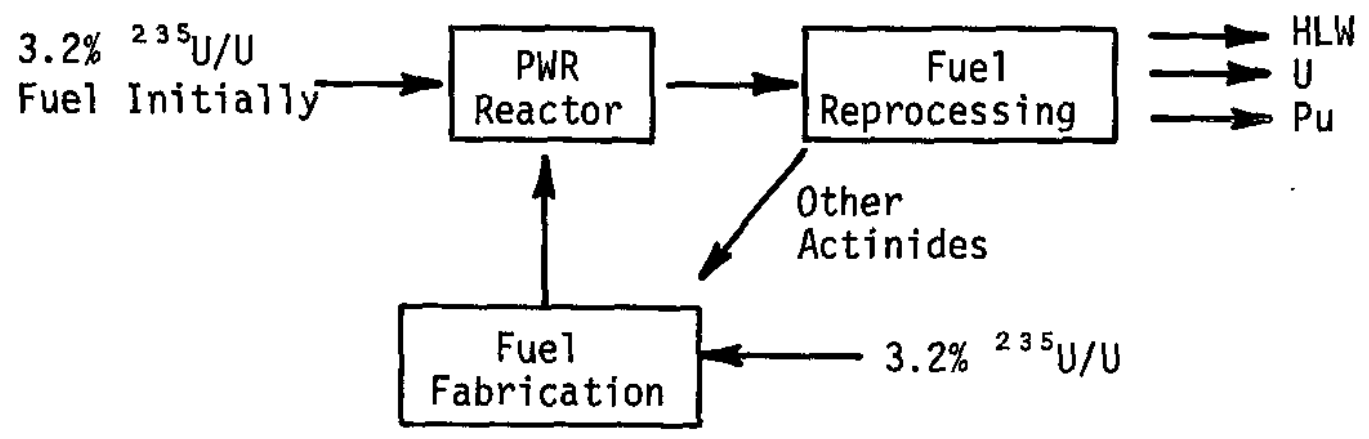

1.2 All actinides from each LWR U-assembly recycled into new assembly with variable ${ }^{235} \mathrm{U}$

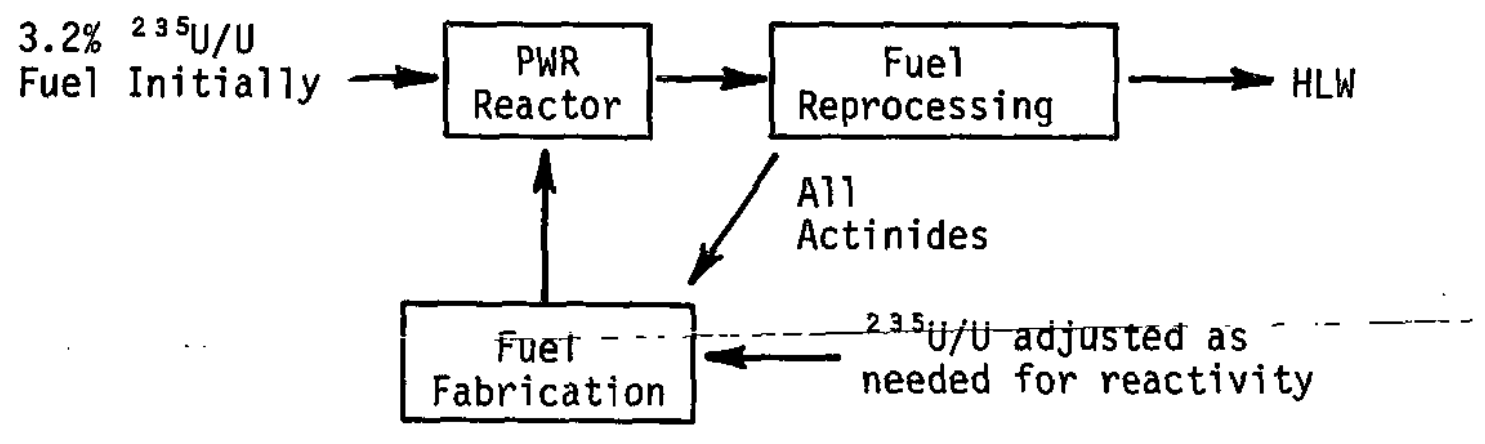

FIGURE 6. Flow Diagrams of Actinide Recycle - Four U Diluent Cases 
1.3 AIl actinides (except $U$ ) from 5 LWR $U$-assemblies recycled into assembly of natural $U$

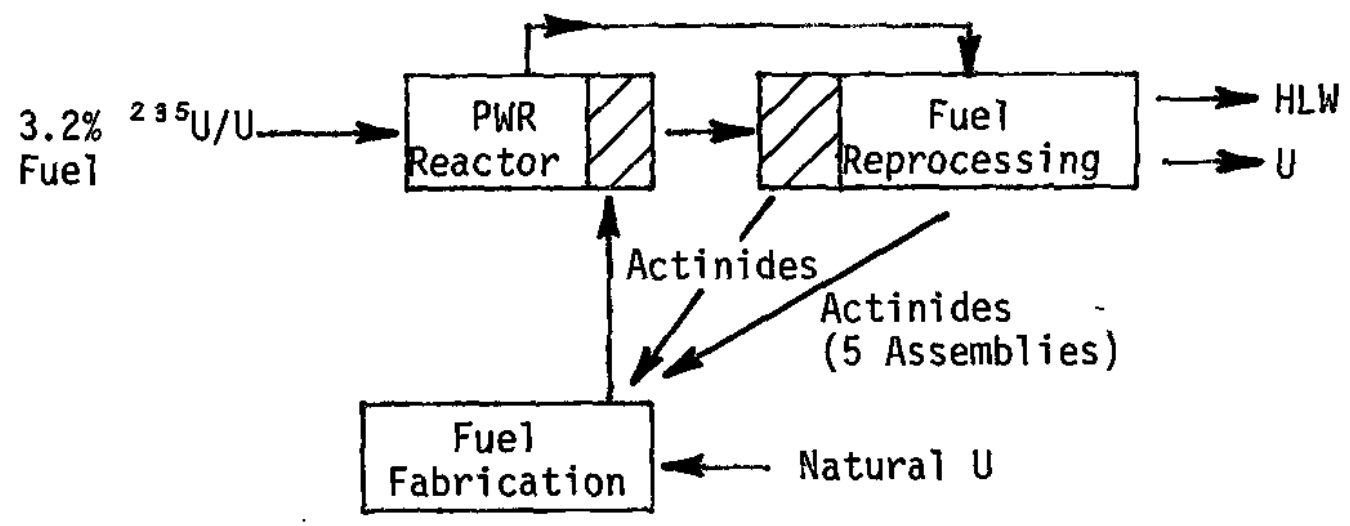

1.4 Waste actinides from 20 LWR U-fuel rods recycled into 1 target rod of depleted U

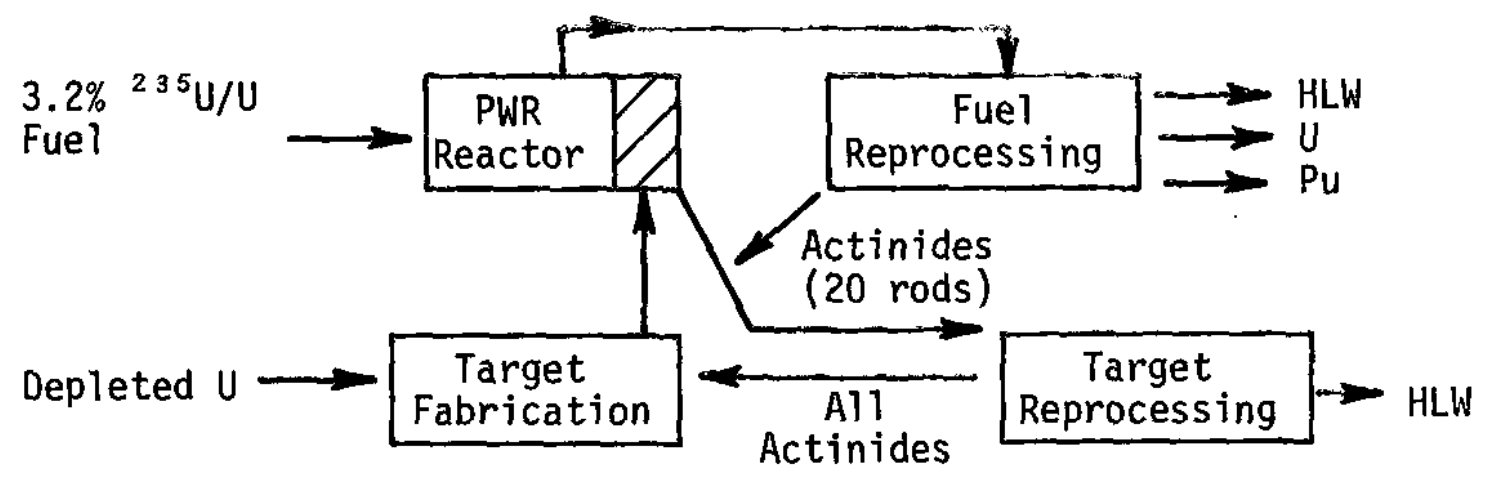

FIGURE 6 . Continued 
2.1 Waste actinides from 100 LWR U-fuel rods recycled into 1 target rod of zirconium

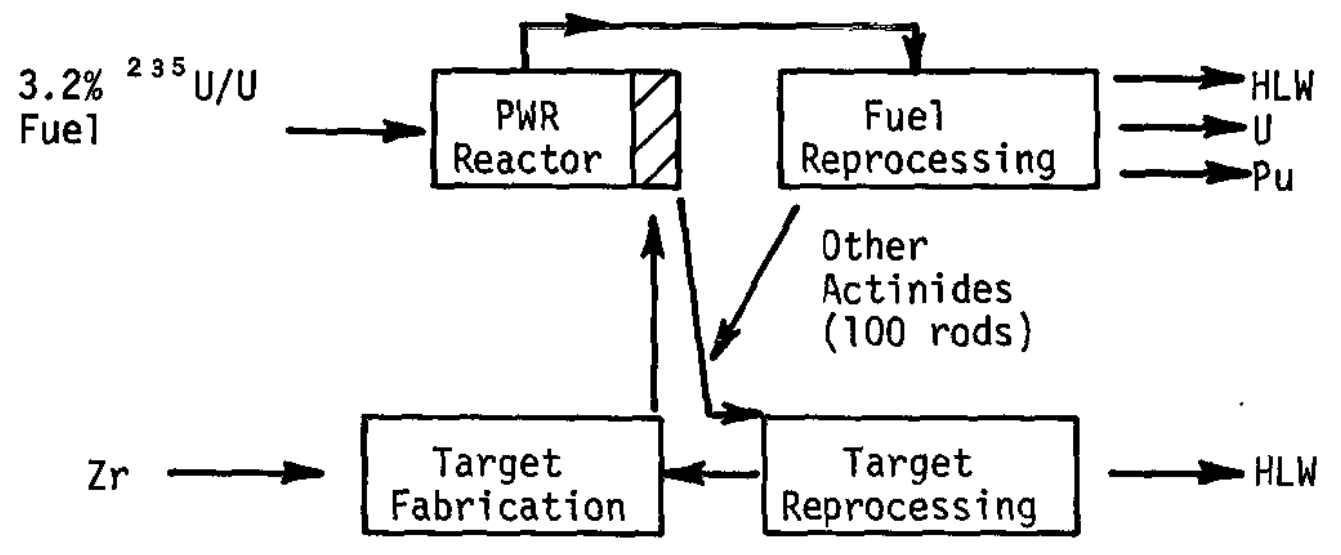

2.2 Waste actinides from 50 LWR U-fuel rods recycled into 1 target rod of zirconium

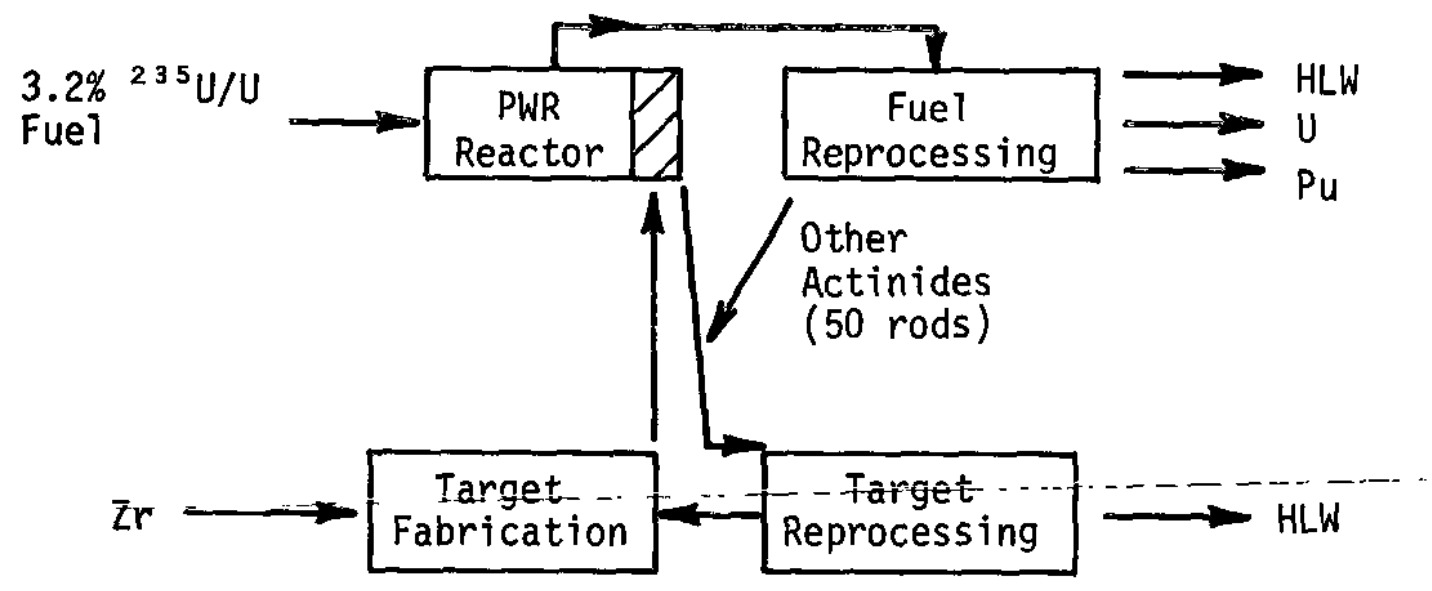

2.3 Waste actinides from 50 LWR U-fuel rods irradiated for 10 consecutive fuel cycles (no reprocessing between cycles)

FIGURE 7. Flow Diagrams of Actinide Recycle - Three $\mathrm{Zr}$ Diluent Cases 
Case 2.3 - Waste actinides from 50 LWR U-fuel rods irradiated for ten consecutive fuel cycles (no reprocessing between cycles).

Group 3 - Waste actinides from advanced charge designs (Figure 8)

Case 3.1 - Waste actinides from five $U$ and two and one-half $\mathrm{Pu}$ fuel assemblies recycled into one target assembly in a mixed $U / P u$ lattice.

Case 3.2 - Waste actinides from $20 \mathrm{U}$ and $10 \mathrm{Pu}$ fuel assemblies recycled into one target assembly in a mixed $\mathrm{U} / \mathrm{Pu}$ lattice.

Case 3.3 - Waste actinides from a Th assembly enriched in ${ }^{23} \mathrm{U}$ and ${ }^{235} \mathrm{U}$ recycled into one new assembly.

Group $4-\mathrm{D}_{2} \mathrm{O}$ Reactor systems (Figure 9)

Case 4.1 - Waste actinides from 100 LWR fuel rods recycled into one target in Savannah River Plant (SRP) $\mathrm{D}_{2} \mathrm{O}$ lattice.

Case 4.2 - Waste actinides from each CANDU-Pu assembly recycled into new assembly.

The choice of diluent is an important consideration in both the chemical partitioning and the reactor transmutation phases of the P-T concept. The waste actinides must be mixed with a diluent to achieve acceptable power generation in the fuel or target rods during reactor operation. If zirconium is used as the diluent, irradiation of the actinides is straightforward, but dissolution of the target rods during chemical recovery operations is difficult. Use of uranium as the diluent simplifies the dissolution operations, but will result in the formation of unwanted actinides during irradiation. The use of both types of diluent was included in the study.

Detailed results from the calculations for each of the twelve cases are presented in subsequent sections of this report. A one year cooling period follows the irradiation period, which is 3 years for most cases. Because reprocessing losses are expected to be smal1, it was assumed that $100 \%$ of the actinides were recovered from fission products and other waste. Contents are expressed in units of grams per metric tonne of original fuel material. Although light water reactors (LWR) could be either pressurized (PWR) or boiling water (BWR), only PWR's were considered in this study. 
3.1 Waste actinides from $5 \mathrm{U}$ and $2 \frac{1}{2} \mathrm{Pu}$ fuel assemblies recycled into 1 target assembly in a mixed U/Pu lattice

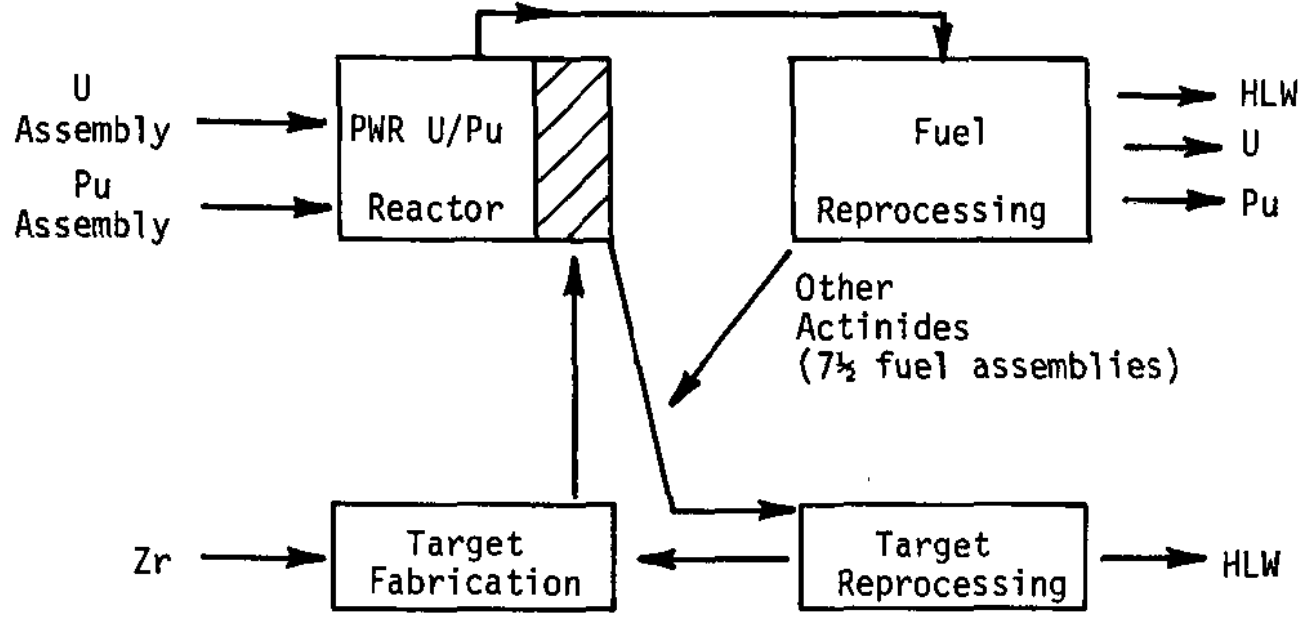

3.2 Waste actinides from $20 \mathrm{U}$ and $10 \mathrm{PU}$ fuel assemblies recycled into 1 target assembly in a mixed U/Pu lattice

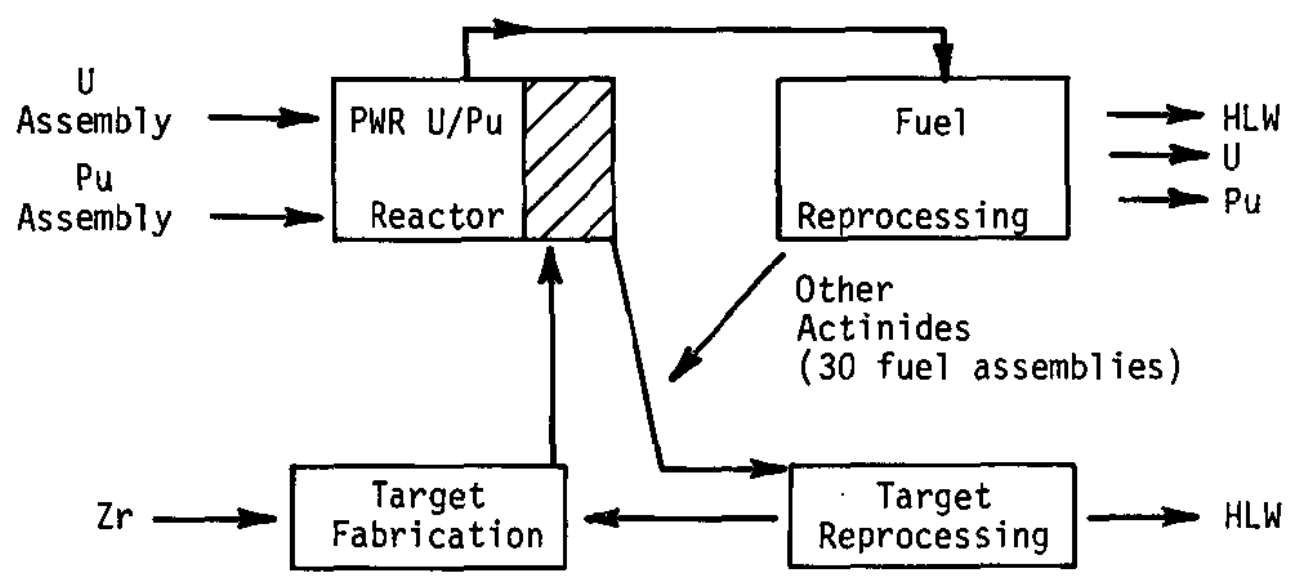

3.3 Waste actinides from a Th assembly enriched in ${ }^{23} \mathrm{U}$ and $235 \mathrm{U}$ recycled into I new assembly

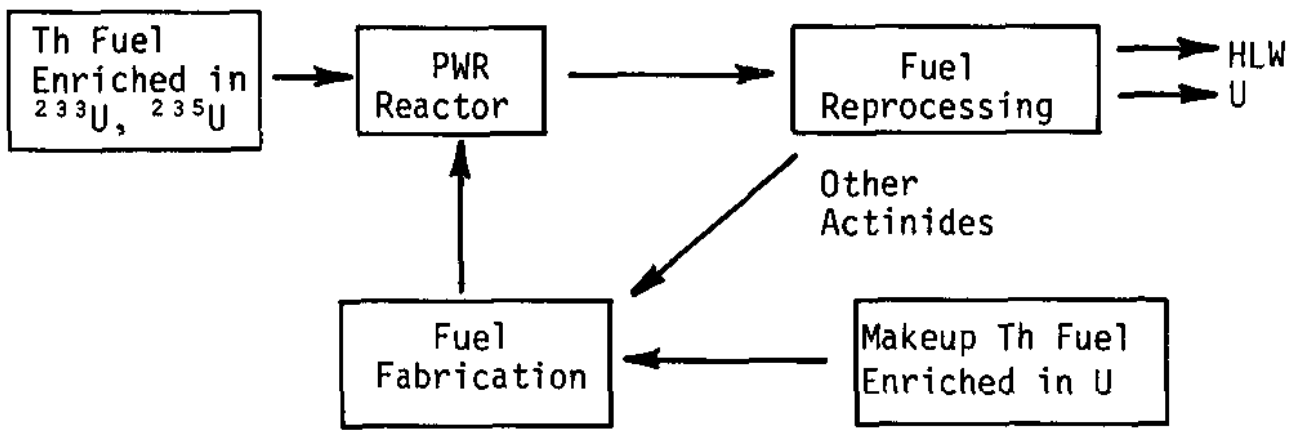

FIGURE 8. Flow Diagram of Actinide Recycle - Two Advanced Charge Designs 
4.1 Waste actinides from 100 LWR fuel rods recycled into 1 target in SRP lattice

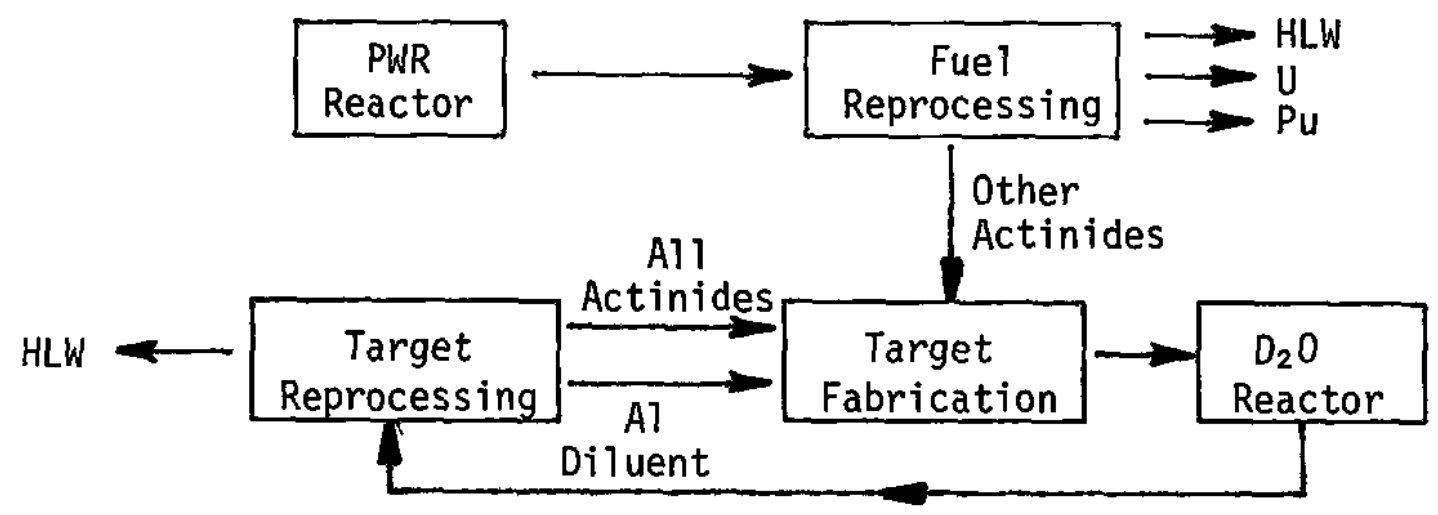

4.2 Waste actinides from each CANDU-Pu assembly recycled into new assembly

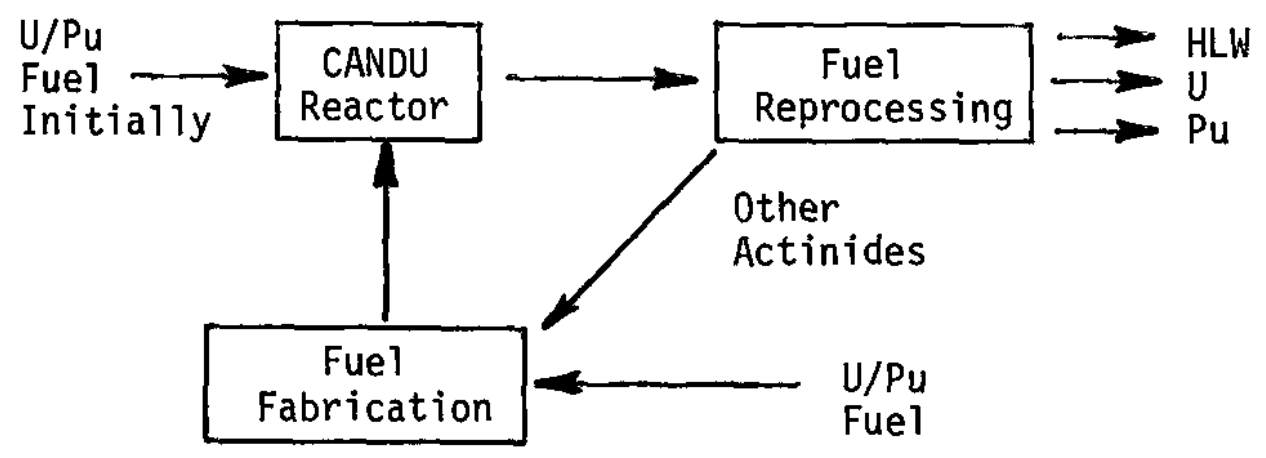

FIGURE 9. Flow Diagrams of Actinide Recycie - Two $\mathrm{D}_{2} \mathrm{O}$ Reactor Cases 
Actinides from LWR Fue] - U DiTuent (Group 1)

All GLASS calculations for Group 1 cases were done with 84 neutron energy groups. The fuel parameters are shown in the last column of Table $1 .^{8}$ The fuel rod arrangement was a $17 \times 17$ square pattern with a rod pitch of 0.496 inch. The pitch used in the calculations was $5 \%$ larger, to mock up $\mathrm{H}_{2} \mathrm{O}$ in empty rod positions in the fuel bundle. A unit cell consisted of $\mathrm{H}_{2} \mathrm{O}$ moderator, cladding, and one fuel rod. The end-of-life exposure was 33,000 MWD/MTM (MTM is the mass of U-meta1 at zero exposure).

The calculated beginning and ending actinide contents of the base-case fuel are shown in Table A.1. The initial ${ }^{235} \mathrm{U}$ enrichment was $3.2 \%$. The total $\mathrm{Pu}$ content was $0.101 \times 10^{5} \mathrm{~g} / \mathrm{MTM}$ of which $56.9 \%$ was ${ }^{239} \mathrm{Pu}$; actinides other than $U$ and $\mathrm{Pu}$ totaled $782 \mathrm{~g} / \mathrm{MTM}$. Cooling time after shutdown was one year.

Case 1.1

The waste actinides (no $U$ or Pu) from one LWR fuel rod were charged to a new fuel rod for 3 years of irradiation to 33,000 MWD/MTM. After a one year cooling and recovery period, all waste actinides were again recycled. Five such recycles were conducted. The initial ${ }^{235} \mathrm{U}$ content was $3.2 \%$ each time. Results are given in Table A.2 and Figure 10.

The ${ }^{237} \mathrm{~Np}$ and ${ }^{243} \mathrm{Am}$ concentrations equilibrated after five recycles, but the higher isotopes of $\mathrm{Cm}$ and $\mathrm{Cf}$ were still increasing. The $\mathrm{Pu}$ assay was changed from the base value, with the ${ }^{238} \mathrm{Pu}$ component raised from $1.7 \%$ to $5.0 \%$. The waste actinide inventory after five recycles was $1488 \mathrm{~g} / \mathrm{MTM}$ compared to $4690 \mathrm{~g} / \mathrm{MTM}$ that would have accumulated without recycle. This is a ratio of 0.32 . However, the fraction of waste actinides fissioned aftor five reeyeies was oniy about $15 \%$, because a all the ${ }^{237} \mathrm{~Np}$ transmuted to $\mathrm{Pu}$ was removed after each fuel cycle in this option.

A static reactivity calculation showed that the reactivity loss resulting from the presence of the waste actinides in recycle 5 could be compensated for by increasing the initial ${ }^{235} \mathrm{U}$ content from $3.2 \%$ to $3.4 \%$. Also, the relatively dilute concentrations of the waste actinides assured that self-shielding of the resonance capture cross sections was not an important consideration in calculating transmutation rates. 


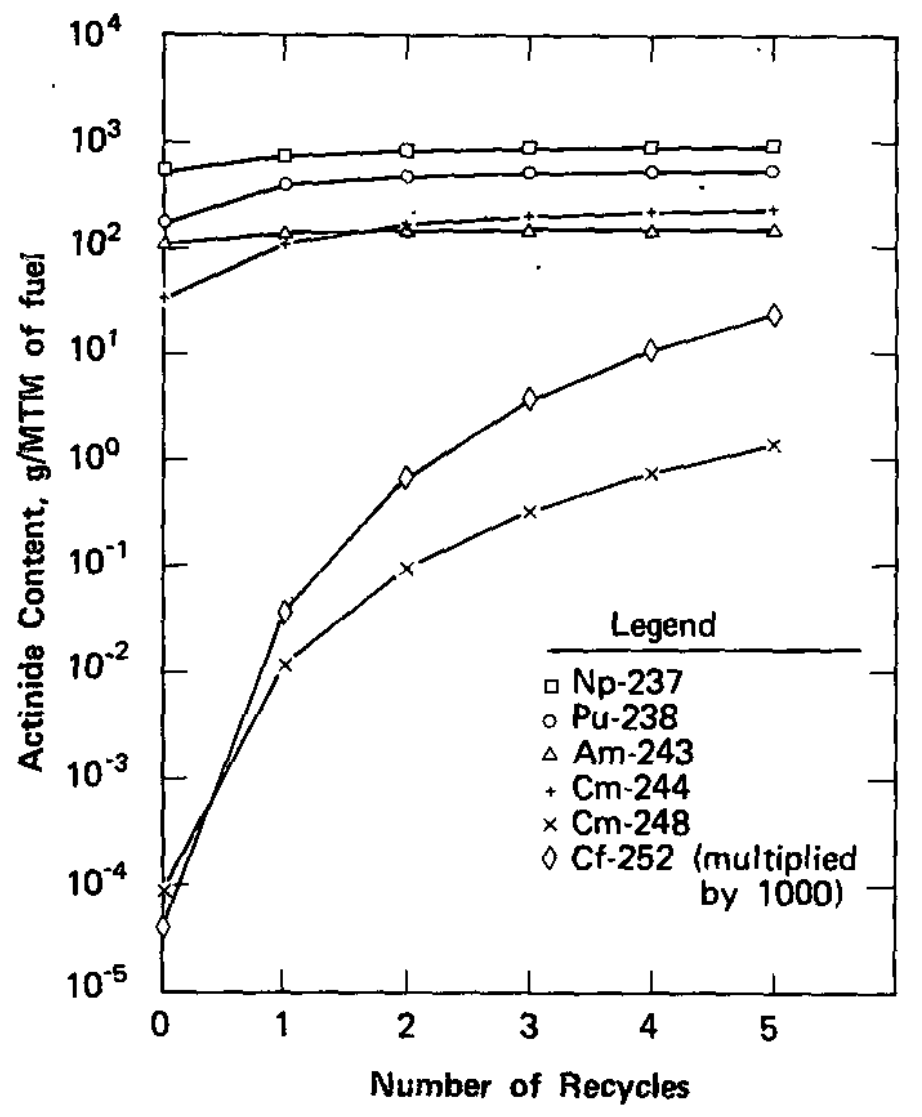

FIGURE 10. Waste Actinides from each LWR U-Assembiy Recycled into New Assembiy - Case 1.1

Case 1.2

All the actinides from one fuel rod were charged to a new $\mathrm{U}$-fuel rod. The ${ }^{235} \mathrm{U}$ content was adjusted to give an initial $k_{\infty}$ value of 1.10 . Irradiation was carried to $33,000 \mathrm{MWD} / \mathrm{MTM}$. After a one year cooling and recovery period, all actinides were again recycled; five such recycles were conducted. The starting ${ }^{235} \mathrm{U}$ required to yield a $\mathrm{k}_{\infty}$ value of 1.10 was as follows for each recycle: $2.0 \%, 2.6 \%, 2.8 \%, 3.2 \%$, and $3.3 \%$, respectively. The increase resulted from both the changing $\mathrm{Pu}$ isotopic fractions and the waste actinide recycle. Cycle-ending contents are given in Table A.3 and Figure 11.

None of the actinide concentrations equilibrated after five recycles, and the higher isotopes of $\mathrm{Cm}$ and $\mathrm{Cf}$ were still increasing rapidly. The ${ }^{238} \mathrm{Pu}$ fraction of the $\mathrm{Pu}$ assay increased from $2 \%$ at the start to $13 \%$ at the end of recycle 5 . The actinide inventory (excluding $U$ ) after five recycles was $0.329 \times 10^{5}$ g/MTM compared to $0.653 \times 10^{5} \mathrm{~g} /$ MTM that would have accumulated without recycle. This ratio is 0.50 . The remaining $50 \%$ of the actinides were fissioned. 


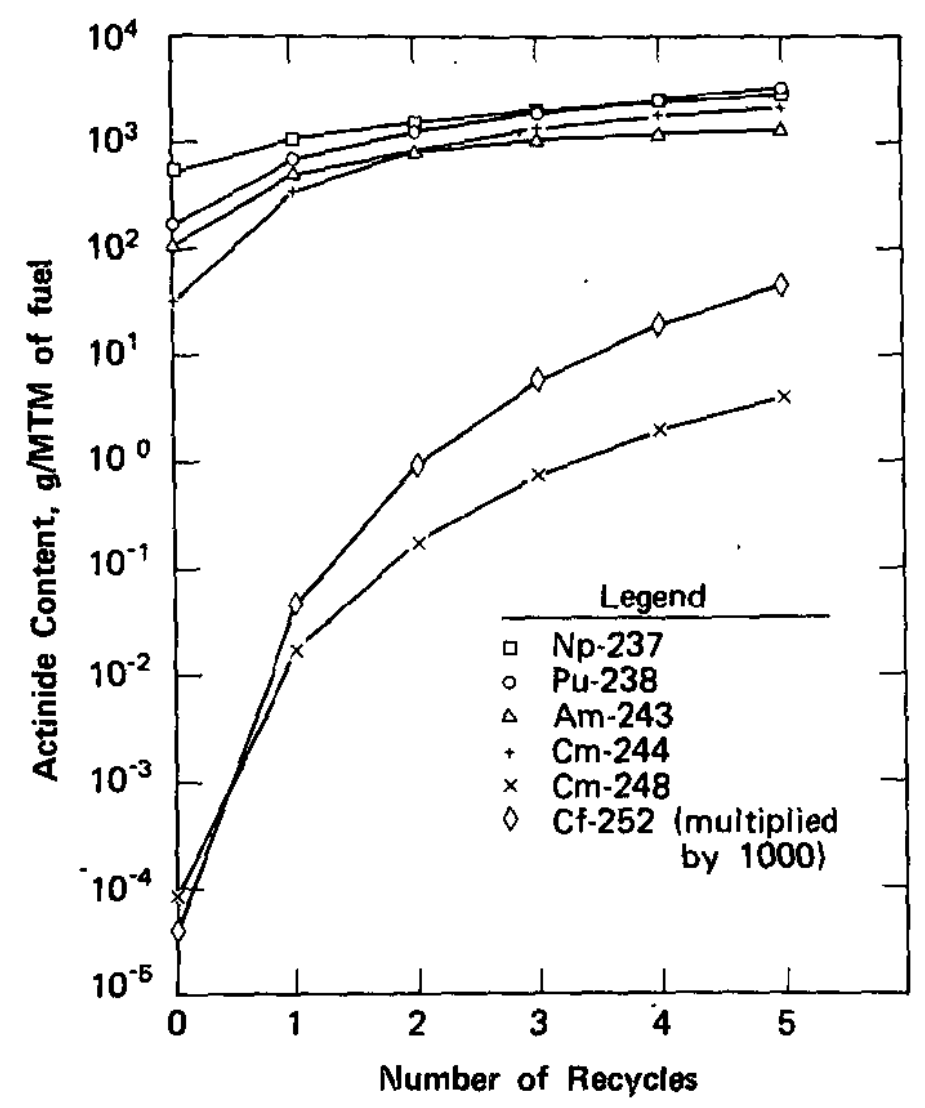

FIGURE 11. All Actinides from each LWR U-Assembly Recycled into New Assembly with Variable $235 \mathrm{U}$ - Case 1.2

\section{Case 1.3}

All the actinides except $U$ from five fuel rods were charged to one rod of natural U. After irradiation to 33,000 MWD/MTM and a one year cooling-recovery period, the actinides were added to those from five additional fuel rods for recyelo.-Initidi reactivity values for five recycles were as follows: 1.11, 1.11, $1.12,1.13$, and 1.15 , respectively. Cycle ending contents are given in Table A.4 in units of g/MTM of the fuel supplying the waste actinides.

The actinide inventory (excluding $U$ ) after five recycles was $0.408 \times 10^{5} \mathrm{~g} / \mathrm{MTM}$ compared to $0.544 \times 10^{5} \mathrm{~g} / \mathrm{MTM}$ that would have accumulated without recycle. This is a ratio of 0.75 . This case is impractical for any extended operation because the new $\mathrm{Pu}$ added from the five regular fuel rods at the start of each recycle far exceeded the $\mathrm{Pu}$ burned, and the $\mathrm{Pu}$ content increased to unacceptable values. If the number of fuel rods supplying $\mathrm{Pu}$ was reduced below five, the reactivity values were too low. 
Case 1.4

The waste actinides (no $\mathrm{U}$ or $\mathrm{Pu}$ ) from $20 \mathrm{LWR}$ fuel rods were charged to one rod of depleted $U$. The target rod was placed in an environment of standard, $3.2 \%{ }^{235} \mathrm{U}$ fuel rods for 3 years of irradiation. The unit cell for GLASS calculations was a $3 \times 3$ array of clad rods in $\mathrm{H}_{2} \mathrm{O}$ moderator. After a one year coolingrecovery period, all the remaining actinides in the target rod were added to the waste actinides from 20 additional fuel rods for recycle. After five recycles, the power of the target rod had equilibrated to a value $20 \%$ greater than the power of the regular fuel rods.

Cycle ending contents are given in Table A.5 and Figure 12 in units of g/MTM of the fuel supplying the waste actinides. The actinide inventory (excluding $U$ ) after five recycles was $3080 \mathrm{~g} / \mathrm{MTM}$ compared to $3910 \mathrm{~g} / \mathrm{MTM}$ that would have accumulated without recycle. This is a ratio of 0.79 . The ratio is greater than 1.0 until after three recycles because of the "unwanted" $\mathrm{Pu}$ produced in the depleted $\mathrm{U}$ diluent.

\section{Comparison of Cases in Group 1}

There are several criteria that can be used to judge the merits of the four cases described. These considerations are. listed below, with yes and no votes applied as appropriate. The statements are worded such that a yes vote is favorable.

\section{Criterion}

- Uranium used as diluent

- Actinides fission rate acceptable

- Disposal of Pu provided for

- Actinides present in "manageable" amounts

- Most of fuel fabrication uncontaminated by actinides

- Only one type of rod in fuel bundle

\begin{tabular}{llll}
\multicolumn{4}{c}{ Case } \\
\hline 1.1 & 1.2 & 1.3 & 1.4 \\
yes & yes & yes & yes \\
no & yes & no & no \\
no & yes & yes & no \\
yes yes & no & yes \\
& & & \\
no & no & yes & yes \\
yes yes & yes & no
\end{tabular}




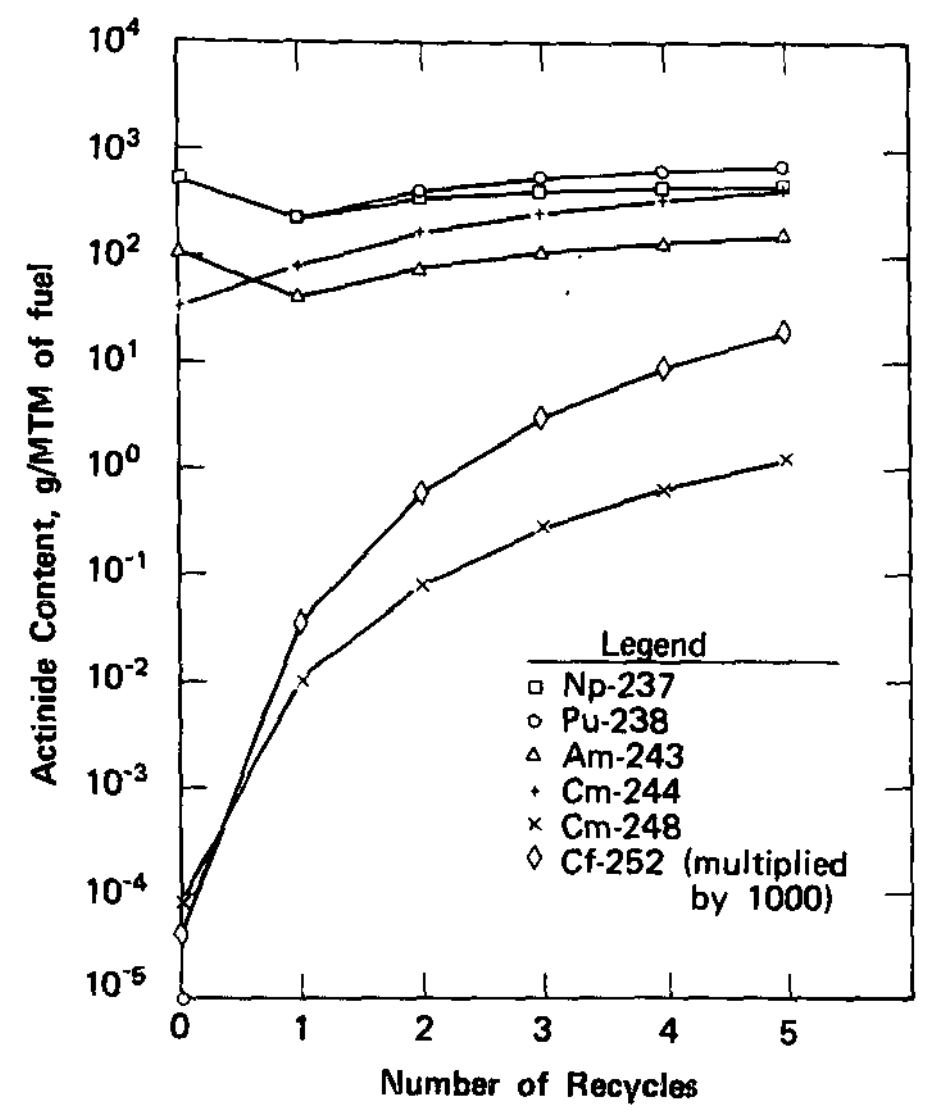

FIGURE 12. Waste Actinides from 20 LWR U-Fue] Rods Recycled into One Target Rod of Depleted U - Case 1.4

The third criterion is important if the $\mathrm{Pu}$ produced in an LWR fuel cycle has no future application, e.g., in a breeder reactor or a $\mathrm{U} / \mathrm{Pu}$ fueled reactor. In Cases 1.1 and 1.4 , the $\mathrm{Pu}$ was not recycled, so a stockpile would accumulate for disposal by some other means. In Cases 1.2 and 1.3 , the Pu cycle was "closed" in that all Pu is returned for fission.

The fourth criterion implies that the recycled actinides were present in amounts that would not require major revision to fuel fabrication technology or reactor operation. Case 1.3 is unacceptable because of the relatively large amounts of $\mathrm{Pu}$ present.

Case 1.2 is the most attractive option of the four. The only negative consideration is the contamination of all the recycled fuel with radioactive actinides; this necessitates shielding in fuel fabrication facilities. One simplifying assumption made in evaluating Case 1.2 was that pure ${ }^{235} U$ would be available. The ratio of ${ }^{23{ }^{8}} \mathrm{U}$ to ${ }^{235} \mathrm{U}$ will in fact be about four. The volume occupied by the additional ${ }^{23 \theta} \mathrm{U}$ is about $7 \%$ 
of the total volume and this necessitates some holdup of the actinide inventory in successive recycles. This case will be pursued further in later studies.

Actinides from LWR Fue1 - Zirconium Diluent (Group 2)

The waste actinides to be disposed of were the same as those considered in the Group 1 calculations (Table A.1). However, zirconium was used as the diluent, and target rods containing actinides were included in the fuel assembly. The difficulties introduced into the chemical recovery operations by the zirconium were recognized; however, the burnup calculations were useful in evaluating actinide fission rates in separate target rods where the diluent is inert. The results are applicable for any other diluent material having a low neutron absorption cross section.

A11 GLASS calculations for Group 2 cases were done in 84 neutron energy groups. The unit cell was a $3 \times 3$ array of clad rods in $\mathrm{H}_{2} \mathrm{O}$ moderator; eight regular LWR fuel rods surrounded the target rod.

Case 2.1

The waste actinides (no $\mathrm{U}$ or $\mathrm{Pu}$ ) from $100 \mathrm{LWR}$ fue 1 rods were charged to one target rod of zirconium. The target rod was placed in an environment of standard $3.2 \%{ }^{235} \mathrm{U}$ fue 1 rods for 3 years of irradiation. After a one year cooling-recovery period, all remaining actinides in the target rod were added to the waste actinides from 100 additional fuel rods for recycle. Five such recycles were conducted. Cycle ending contents are given in Table A. 6.

The total actinide inventory after 5 recycles was $63 \%$ of the inventory if there were no recycle, i.e., 37\% of the actinides were fissioned. The ratio of the thermal neutron flux in the target to that in the adjacent fuel rods was 0.67 . However, this case is not acceptable because the target rod power was excessive. After five recycles, the power of the target rod exceeded the fuel power by $50 \%$, and had not equilibrated.

Case 2.2

This case differs from the preceding one in that the source of waste actinides was 50 fuel rods rather than 100 . Cycle ending contents are given in Table A.7 and Figure 13. Forty-six percent of the waste actinides were fissioned after five recycles. The ratio of target to fuel rod thermal neutron flux was 0.90 . The ratio of target to fue 1 rod power was 0.90 after five recycles and would equilibrate at about 1.1. Actinides in the target rod were primarily ${ }^{237} \mathrm{~Np},{ }^{23}{ }^{8} \mathrm{Pu},{ }^{243} \mathrm{Am}$ and ${ }^{244} \mathrm{Cm}$. 


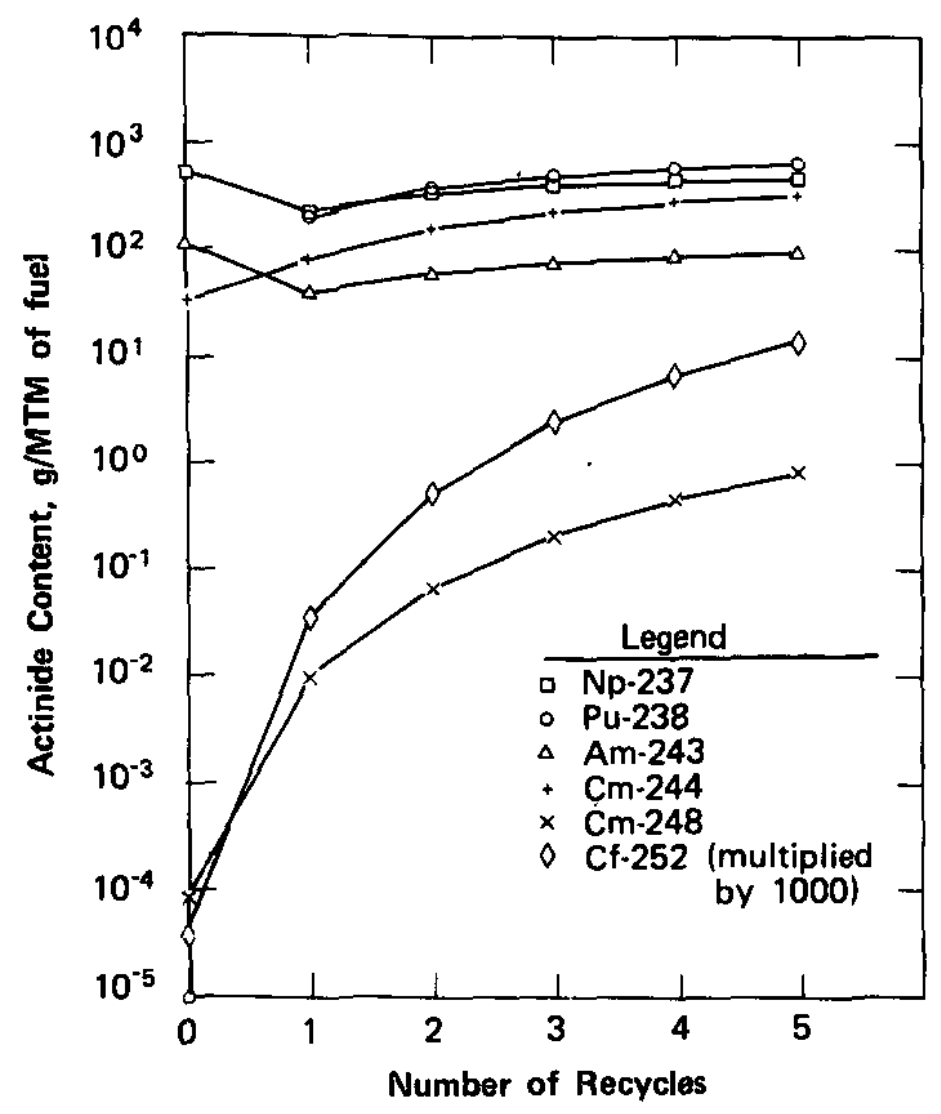

FIGURE 13. Waste Actinides from 50 LWR U-Fuel Rods Recycled into One Target Rod of Zirconium - Case 2.2

\section{Case 2.3}

The waste actinides (no $U$ or $\mathrm{Pu}$ ) from 50 LWR fuel rods were charged to one target rod of zirconium. The target rod was irradiated for ten consecutive fuel cycles without interruption in an environmont of standart $3.2 \frac{2}{\circ}{ }^{2}$ s ${ }^{5} \mathrm{y}$ fue $\overline{\mathrm{I}}$ rods.-Cycle-ending contents are shown in Table A. 8 and Figure 14. Ninetysix percent of the actinides were fissioned during ten cycle (30 year) irradiation. By the tenth recycle transuranic nuclides through $247 \mathrm{Cm}$ were decreasing with exposure.

Comparison of Cases in Group 2

Cases 2.2 and 2.3 each constitute a reasonable method for fissioning the waste actinides in separate target rods. About $10 \%$ of the actinides present were fissioned each fue 1 cycle. The irradiation of the same target rod for several consecutive fuel cycles may not be feasible because of irradiation damage to the zirconium clad. Special disassembly techniques would be required to separate target rods from regular fuel rods before shearing. 
The reactivity of a lattice containing five target rods per fuel assembly (Case 2.2) would be reduced by about $2 \% \Delta \mathrm{k}_{\infty}$ after five recycles. The five target rods could accommodate all the recycled waste actinides of one fuel assembly.

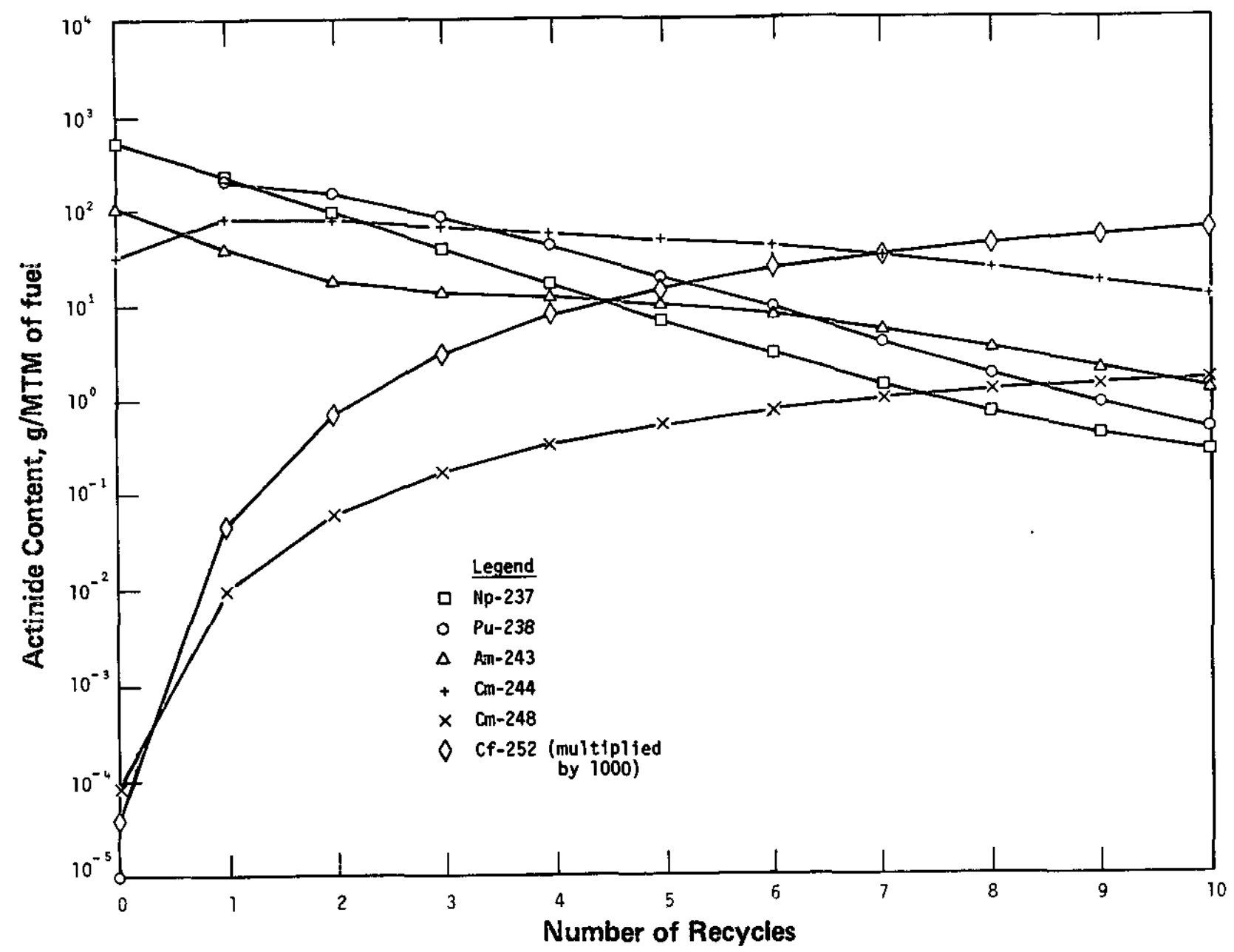

FIGURE 14 Waste Actinides from 50 LWR U-Fuel Rods Irradiated for Ten Consecutive Fuel Cycles - Case 2.3 
Actinides from Advanced-Charge Design (Group 3)

Two advanced-charge design types were investigated. They were a mixed $\mathrm{U} / \mathrm{Pu}$ lattice and a Th lattice enriched in ${ }^{23}{ }^{3} \mathrm{U}$ and ${ }^{235} \mathrm{U}$. In Cases 3.1 and 3.2 a separate target assembly with actinides was irradiated in a lattice of $U$ and $\mathrm{Pu}$ fuel assemblies. In Case 3.3, the waste actinides from $T h / U$ fuel were homogeneously mixed with the fuel for recycle. This mixing is similar to Case 1.1.

\section{Case 3.1}

Figure 8 shows the flow diagram for this case. It was assumed that the reactor charge was made of $\mathrm{U}$ and $\mathrm{U} / \mathrm{Pu}$ assemblies with the initial contents given in Tables A.1 and A.9, respectively. The initial contents of each type were the same for all recycles. The waste actinides (no $U$ or $\mathrm{Pu}$ ) from the $U$ and $U / \mathrm{Pu}$ assemblies were combined into one separate target assembly with zirconium diluent. After one fuel cycle, all remaining actinides in the target were recovered and combined with a new batch of waste actinides for the next recycle.

A cylindricized model of a complete LWR assembly was developed for use in the GLASS code. (In all cases considered in the Group I or 2 options, a cell consisted of either a single fuel rod or eight fuel rods surrounding a target rod.) Geometry restrictions require that a full assembly in an array of assemblies be approximated by concentric rings of clad, fuel and coolant. The chosen model consisted of eight fuel rings, each having a core width equal to the radius of one fuel rod to preserve the surface to volume (S/4V) ratio of the rod geometry. Spaces between the fuel rings were filled with $\mathrm{H}_{2} \mathrm{O}$ coolant.

The beginning and ending reactivity calculated for the annular model of an LWR U-assembly differed from that for a single U-fuel rod teli by oniy $0.4 \% \mathrm{k}{ }^{-}$- Also; the actinide-content ${ }^{-}$per metric tonne of $U$ at $33,000 \mathrm{MWD} / \mathrm{MTM}$ agreed well with that calculated for the single rod. Thus, actinide depletion rates could be accepted with confidence if the rates were calculated by using the annular mode1.

The supercell used for recycle calculations consisted of an actinide target assembly surrounded by four $U$ assemblies and four $\mathrm{U} / \mathrm{Pu}$ assemblies. Because of symmetry restrictions in the model, the two to one ratio of $U$ to $U / P u$ assemblies in the lattice could have been achieved only at the expense of excessive computer time. Al1 calculations were done using 37 neutron energy groups. 
Initial static reactivity calculations showed that if the target assembly contained actinides in the innermost fuel positions, the thermal neutron flux was strongly depressed in the center. To achieve higher fluxes and higher transmutation rates in the target material, waste actinides were loaded only in the outer positions of the cell. The outer positions comprise about $65 \%$ of the total fuel volume available. The inner positions contained $\mathrm{H}_{2} \mathrm{O}$.

The waste actinide content of the two types of fuel assemblies at the end of one 3-year cycle are compared in Table A.10. Column 1 lists the contents calculated when using the single rod model for $U$ (Case 1.1, Table A.1). Columns 2 and 3 give contents calculated in the $U$ and $U / P u$ assemblies when using the nine assembly model. Waste actinides in the $\mathrm{U} / \mathrm{Pu}$ assembly are about four times those in the $U$ assembly. The ${ }^{237} \mathrm{~Np}$ content is about one..third that of the $U$ assembly, but the $A m$ and Cm contents are 10 to 100 times that of the U assembiy.

The waste actinides from five $U$ and two and one-half $U / P u$ assemblies were combined in one target assembly for recycle. Calculated contents of the target assembiy at the end of each recycle are given in Table A.11 and Figure 15. Fifty-four percent of the waste actinide inventory was fissioned. The $\mathrm{Pu}$ assay is made up primarily of the even numbered $\mathrm{Pu}$ isotopes; the fissile isotopes comprise only $14 \%$ of the total $\mathrm{Pu}$ after five recycles.

The specific power of the waste actinide assembly was only one-third that of the fuel assemblies after five recycles, Thus, the actinide loading could be increased to reduce the total number of target assemblies required in the lattice. The resulting penalty is depression of the thermal neutron flux in the target and increased resonance self-shielding; both effects reduce the rate of actinide fissions.

The fission power of the U/Pu assembly was about $10 \%$ greater than the fission power of the $U$ assembly.

Case 3.2

In this case waste actinides were supplied by $20 \mathrm{U}$ and 10 $\mathrm{U} / \mathrm{Pu}$ fuel assemblies (Case 3.1 had five $U$ and two and one-half $\mathrm{U} / \mathrm{Pu}$.) The specific power of the target assembly was equal to that of the fuel assemblies after five recycles and was approaching equilibrium. 


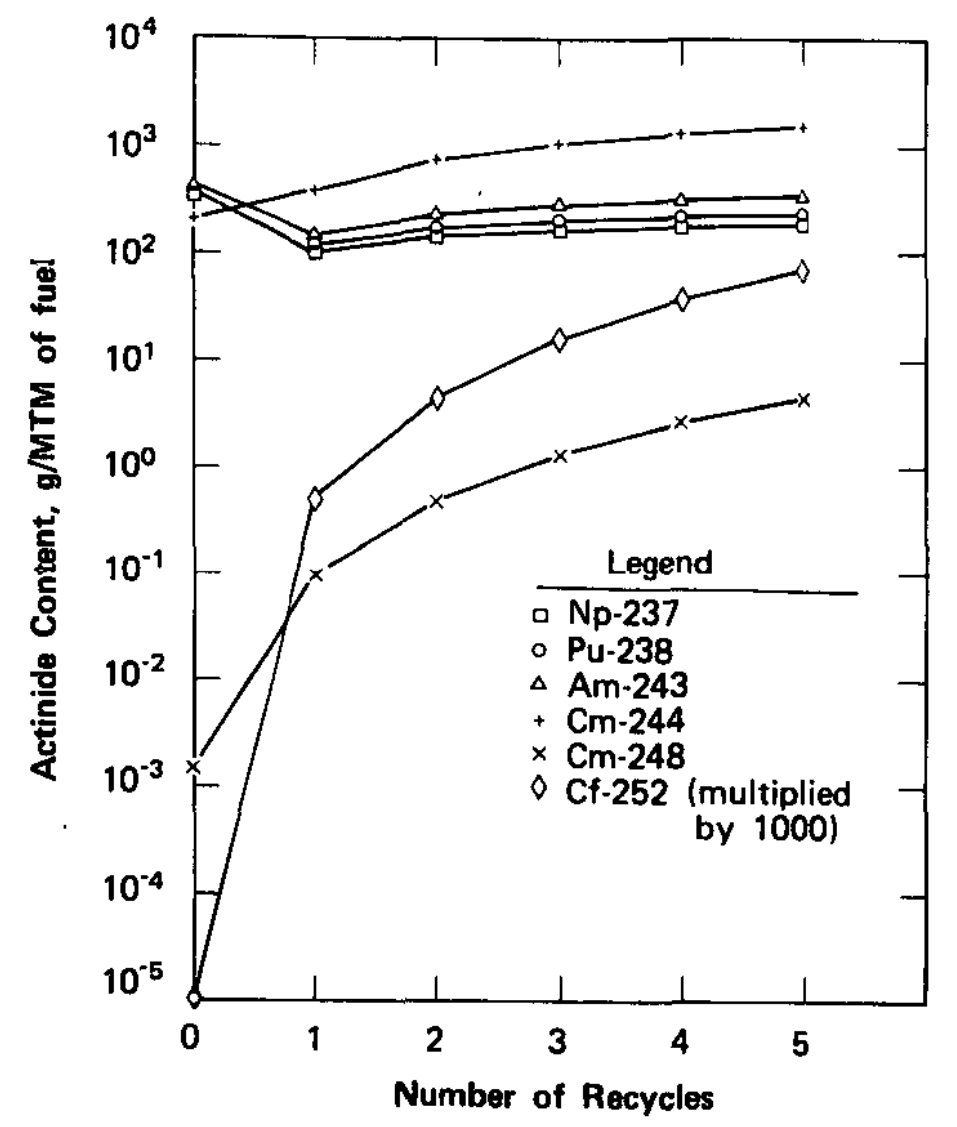

FIGURE 15. Waste Actinide Content of Light Target Assembly in U/Pu Lattice - Case 3.1

Calculated contents of the target assembly are given in Table A.12 and Figure 16. Only $25 \%$ of the actinides were fissioned. Because equilibrium content values were not reached after five recyclos, it is improper to eontiude that the fong-term-fission rate for Case 3.2 is only half that for Case 3.1. However, the results do show that the transmutation rate is very sensitive to the waste actinide loading of a separate target assembly.

\section{Case 3.3}

This case approximates the irradiation conditions expected in a thorium lattice enriched in ${ }^{23} \mathrm{U}$ and ${ }^{235} \mathrm{U}$. A single fuel rod was used to represent the assembly, which was a composite of the $\mathrm{U}$ loadings predicted for a lattice containing both ${ }^{23} \mathrm{U}-$ enriched and $235 \mathrm{U}$-enriched Th assemblies. ${ }^{9}$ 
Initial $U$ Content of Composite Rod

$\begin{array}{cr}\text { Isotope } & \text { Wt \% } \\ 2{ }^{3} \mathrm{U} & 1.8 \\ { }^{23} \mathrm{U} & 0.9 \\ { }^{2} \mathrm{U} & 2.1 \\ { }^{35} \mathrm{U} & 1.3 \\ { }^{236} \mathrm{U} & 0.2\end{array}$

After irradiation to $33,000 \mathrm{MWD} / \mathrm{MTM}$ and recovery, all actinides except $U$ were recycled into a new rod. The initial $U$ content was the same for all five recycles. Ending contents are given in Table A. 13 .

The ${ }^{238} \mathrm{Pu}$ content after five recycles is relatively high $(2570 \mathrm{~g} / \mathrm{MTM})$. The high initial ${ }^{236} \mathrm{U}$ content (1.3\%) promotes the production of ${ }^{237} \mathrm{~Np}$ and ${ }^{238} \mathrm{Pu}$. The ${ }^{248} \mathrm{Cm}$ content is lower than for any other case studied, because of the reduced quantities of total $\mathrm{Pu}$ and Am. Forty-eight percent of the actinides (excluding U) were fissioned in five recycles.

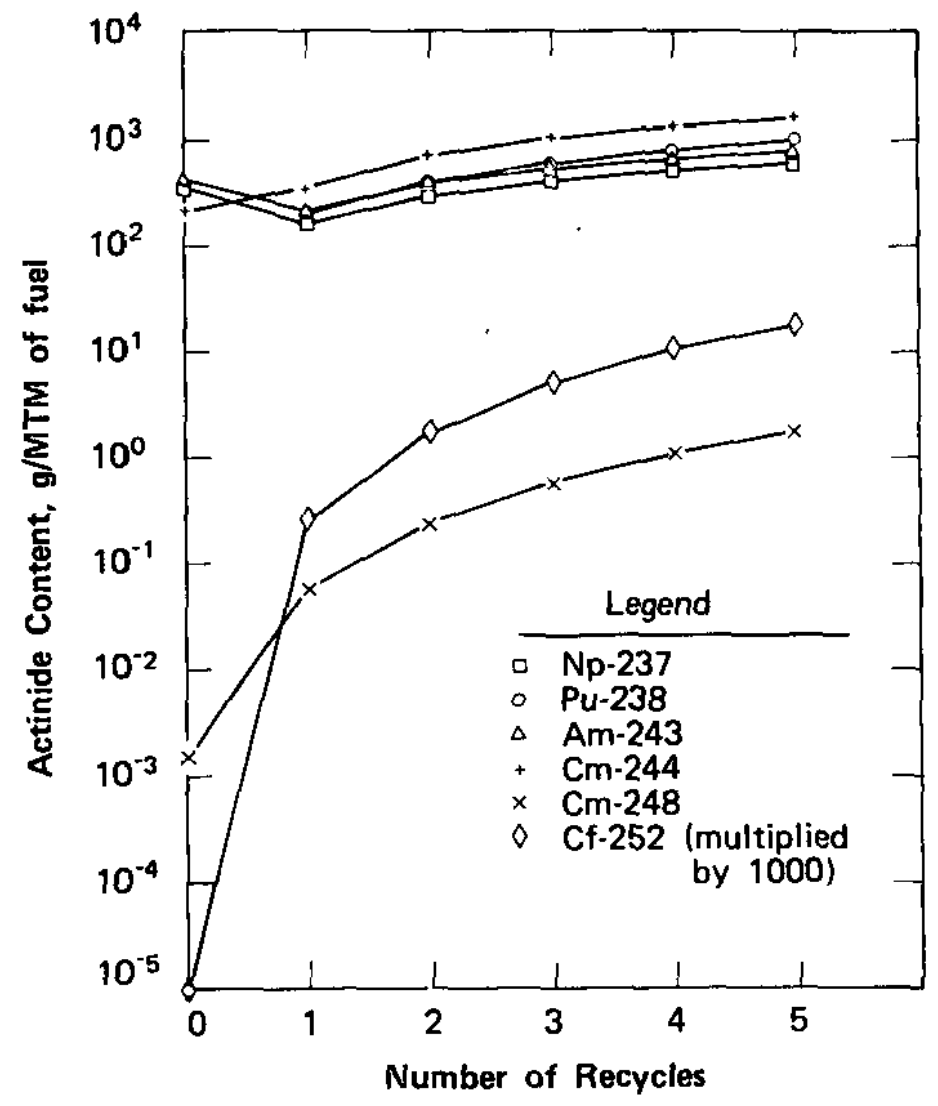

FIGURE 16. Waste Actinide Content of Heavy Target Assembly in U/Pu Lattice - Case 3.2 
A static reactivity calculation showed that the reactivity loss resulting from the waste actinides in recycle 5 could be compensated for by increasing the initial ${ }^{23}{ }^{3} \mathrm{U}$ content from $1.8 \%$ to $2.2 \%$.

Actinides Irradiated in $\mathrm{D}_{2} \mathrm{O}$ Reactors (Group 4)

Case 4.1

If waste actinides (excluding $U$ and $P u$ ) from LWR fuel were irradiated in a Savannah River production reactor, significantly higher fission rates could be achieved than in any standard LWR reactor.

The waste actinides from 100 LWR fuel rods were charged to one aluminum target rod, which was placed in a 13 foot tubular fuel assembly containing $3300 \mathrm{~g}{ }^{23} 5 \mathrm{U}$. The fuel assembly was operated at a power of $6.5 \mathrm{MW}$ for 10 months, or about $70 \%$ burnup. After a one year cooling period, the waste actinides were recovered and added to waste actinides from an additional 100 LWR fuel rods for recycle. Five recycles were conducted. Ending contents are given in Table A.14 and Figure 17.

Recycle 5 contents for this case are very similar to those for Case 2.1, in which actinides from 100 fuel rods were irradiated in a separate target in a LWR lattice. However, the total elapsed time for Case 4.1 is only nine years and for Case 2.1 it is twenty years. In Case 4.1 thirty-five percent of the actinides were fissioned; and the ratio of target power to fuel power was 0.08 at the end of recycle 5. A more efficient mode of operation is to extend the irradiation of a target to several fuel cycles, and thus reduce time out of the reactor.

The use of any high $\bar{p} \overline{o w} \bar{r}$ deñsity reactor for fissioning the waste actinides introduces additional considerations into the transmutation concept. Even if existing reactors were used, new designs for fuel and target as well as means for shipping components would be required. Unless a new reactor design provides for the generation of steam or electricity, the cost of operating the reactor would probably be charged to the actinide program. In an SRP reactor, the energy from both the ${ }^{235} \mathrm{U}$ fissions and the waste actinide fissions would be discharged as waste heat. Perhaps the production of special isotopes such as ${ }^{2{ }^{3} \mathrm{Pu}},{ }^{244} \mathrm{Cm}$, or ${ }^{60} \mathrm{Co}$ could help defray the cost. 


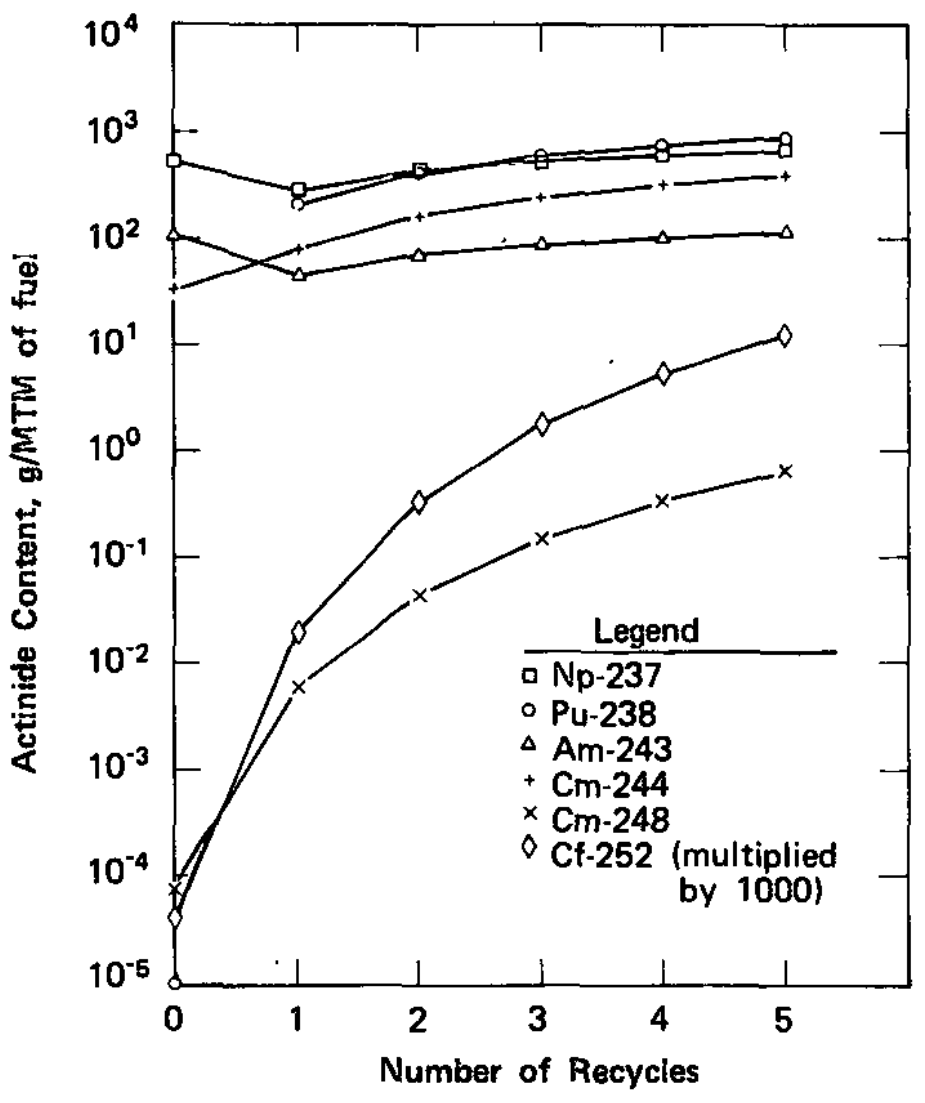

FIGURE 17. Waste Actinides from 100 LWR U-Fuel Rods Recycled into Target in SRP Lattice - Case 4.1

Case 4.2

Actinide production and transmutation calculations were made for the CANDU-Pickering lattice. Figure 18 shows the fuel rod configuration in the assembly. A cylindricized model was developed to represent the 28 fuel rods as three concentric rings for GLASS calculations. Columns 1 and 2 in Table A.15 show the beginning and ending contents of natural uranium fuel irradiated to $8000 \mathrm{MWD} / \mathrm{MTM}$ for about 1.2 years. Ending contents have been cooled one year.

Initial CANDU fuel contents for a Pu recycle mode were obtained from Reference 10. The beginning and ending contents, at an exposure of $8000 \mathrm{MWD} / \mathrm{MTM}$, are given in Table A.15. Boron at $20 \mathrm{ppm}$ was added to the $\mathrm{D}_{2} \mathrm{O}$ moderator to reduce the reactivity to equal that calculated for the natural uranium lattice. The waste actinides (no $U$ or $\mathrm{Pu}$ ) from one assembly were charged to a new assembly for irradiation. After a one year period for cooling and recovery, all waste actinides were again recycled. Five such recycles were conducted. The inttial $\mathrm{U}$ and $\mathrm{Pu}$ contents were the same each time. Results are given in Table A.16 and Figure 19. 


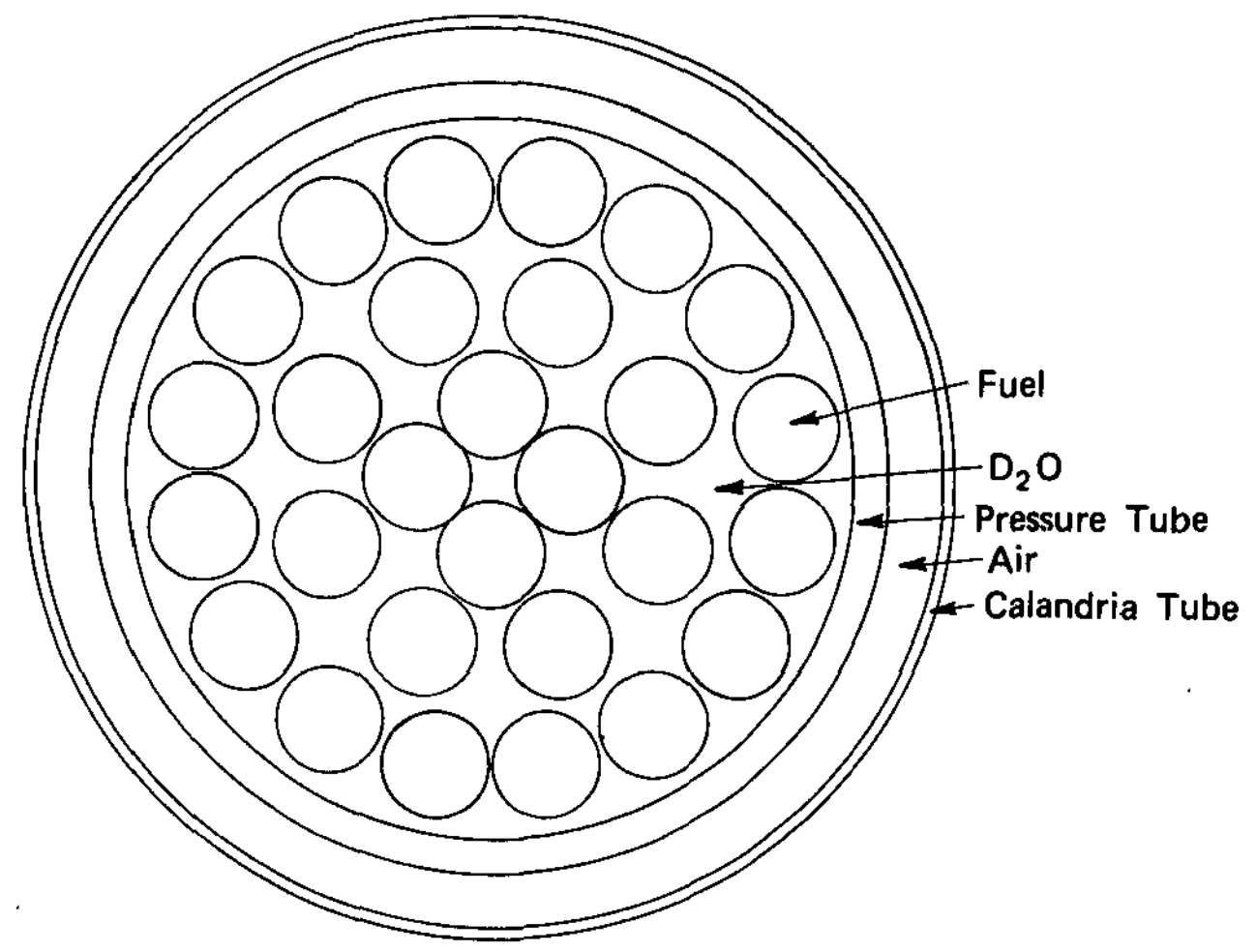

FIGURE 18. CANDU-Pickering Assembly

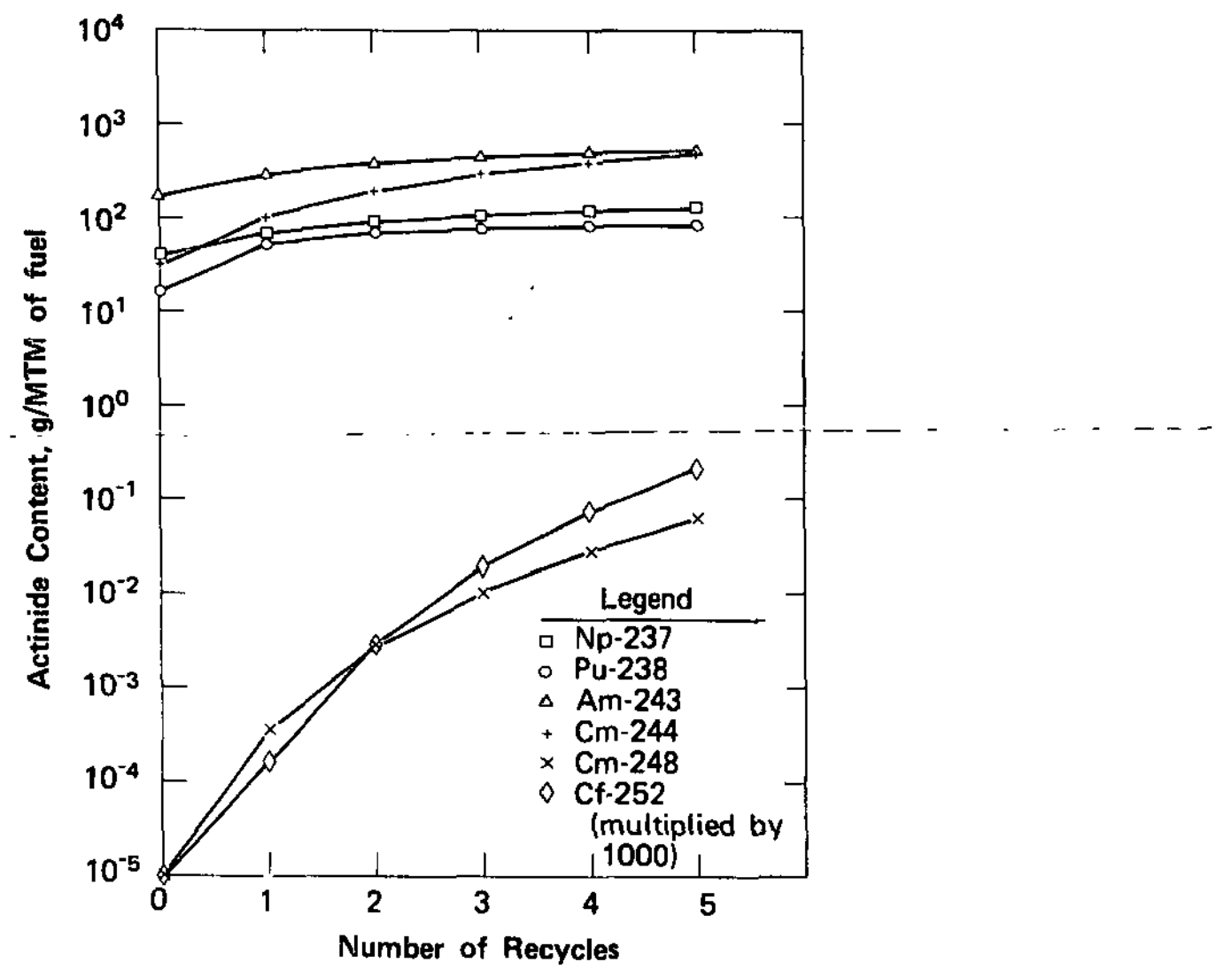

FIGURE 19. Waste Actinides from Each CANDU U/Pu Assembly Recycled into New Assembly - Case 4.2 
As in the Pu-enriched Cases 3.1 and 3.2 the ${ }^{237} \mathrm{~Np}$ fraction of waste actinides is very low (210\%). As a result, the ${ }^{238} \mathrm{Pu}$ fraction of the $\mathrm{Pu}$ is also low $(<1 \%)$. About $34 \%$ of the waste actinides were fissioned in five recycles. The reactivity loss resulting from the addition of the waste actinides was $1.6 \%$ in $k_{\infty}$ after five recycles, but removal of $13 \%$ of the boron in the $D_{2}^{\infty} 0$ moderator restored the $k_{\infty}$ to its base-case value.

\section{FUTURE STUDY}

of the four cases in which actinides were recycled in some type of U-assembly (Group 1, Figure 6). Case 1.2 was the most attractive. All actinides including $\mathrm{Pu}$ were recycled, i.e., the system was "closed". In addition to being an effective waste management alternative, this case is also desirable for safeguards or non-profileration considerations. The $\mathrm{Pu}$ isotopes are always diluted by $U$, and therefore would be more difficult to recover for weapons production. Case 1.2 will be examined more in future studies.

Irradiation of actinides in target rods in a U-fuel assembly (Group 2, Figure 7), would be difficult because special handling is required during assembly and disassembly of the fuel rod bundle. All irradiated fuel assemblies containing several target rods would require partial disassembly before shearing. No further work is planned for Group 2 cases.

If $\mathrm{Pu}$ material will not be fissioned with the waste actinides, the use of separate target assemblies is attractive (Group 3, Figure 8). Fuel and target materials must be kept separated, but an entire target assembly could be processed without special disassembly measures. The use of zirconium as a diluent is the major disadvantage. Recycle of waste actinides in a separate target in mixed $\mathrm{U} / \mathrm{Pu}$ lattices will be examined more in future studies. 
TABLE A. 1

Beginning and Ending Actinide Content of Base-Case LWR Fuel, g/MTM

BEGIN END (OAE YEAR DECAY)

\begin{tabular}{|c|c|c|}
\hline $\begin{array}{l}\text { U232 } \\
\text { U233 } \\
\text { U234 } \\
\text { U235 } \\
\text { U235 } \\
\text { U238 }\end{array}$ & $\begin{array}{l}0.0 \\
0.0 \\
0.29940 \quad 03 \\
0.32000 \quad 05 \\
0.0 \\
0.96770 \quad 06\end{array}$ & $\begin{array}{l}0.52390-03 \\
0.18030-04 \\
0.1535003 \\
0.9136004 \\
0.4009004 \\
0.9428006\end{array}$ \\
\hline NP237 & 0.0 & 0.5225003 \\
\hline 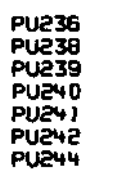 & $\begin{array}{l}0.0 \\
0.0 \\
0.0 \\
0.0 \\
0.0 \\
0.0 \\
0.0\end{array}$ & $\begin{array}{l}0.10900-02 \\
0.1728003 \\
0.5744004 \\
0.2362004 \\
0.1269004 \\
0.5507003 \\
0.23110-01\end{array}$ \\
\hline $\begin{array}{l}\text { AMEY I } \\
\text { AMEY } 2 M \\
\text { AMZ4 } 3\end{array}$ & $\begin{array}{l}0.0 \\
0.0 \\
0.0\end{array}$ & $\begin{array}{l}0.1111003 \\
0.7269000 \\
0.1090003\end{array}$ \\
\hline $\begin{array}{l}\text { CM242 } \\
\text { CM243 } \\
\text { CM244 } \\
\text { CM245 } \\
\text { CM246 } \\
\text { CM247 } \\
\text { CM248 }\end{array}$ & $\begin{array}{l}0.0 \\
0.0 \\
0.0 \\
0.0 \\
0.0 \\
0.0 \\
0.0\end{array}$ & $\begin{array}{l}0.3367001 \\
0.3456000 \\
0.3319002 \\
0.1610001 \\
0.19410000 \\
0.19340-02 \\
0.84350-04\end{array}$ \\
\hline Ox249 & 0.0 & $0.47250-06$ \\
\hline $\begin{array}{l}\text { CF249 } \\
\text { CF250 } \\
\text { CF251 } \\
\text { CF252 }\end{array}$ & $\begin{array}{l}0.0 \\
0.0 \\
0.0 \\
0.0\end{array}$ & $\begin{array}{l}0.72000-06 \\
0.28940-06 \\
0.10700-06 \\
0.39160-07\end{array}$ \\
\hline $\begin{array}{l}\text { SUM U } \\
\text { SUM PU } \\
\text { SUM ACT } \\
\text { SUM ALL }\end{array}$ & $\begin{array}{l}0.1000007 \\
0.0 \\
0.0 \\
0.1000007\end{array}$ & 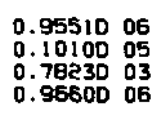 \\
\hline
\end{tabular}


TABLE A.2

\section{Waste Actinides From Each LWR U-Assembly Recycled Into New Assembly - Case 1.1}

\begin{tabular}{|c|c|c|}
\hline & BASE CASE & RECYCLE I \\
\hline $\begin{array}{l}\text { ve } 32 \\
\text { ve } 33 \\
\text { ve34 } \\
\text { ve35 } \\
\text { ve36 } \\
\text { ve38 }\end{array}$ & $\begin{array}{l}0.52390-03 \\
0.18030-04 \\
0.1536003 \\
0.8136004 \\
0.4008004 \\
0.9428008\end{array}$ & $\begin{array}{l}0.13290-02 \\
0.76740-04 \\
0.1593003 \\
0.8235004 \\
0.3998004 \\
0.9420006\end{array}$ \\
\hline NP237 & 0.5225003 & 0.7469003 \\
\hline 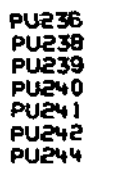 & $\begin{array}{l}0.10900-02 \\
0.1728003 \\
0.5744004 \\
0.2362004 \\
0.1269004 \\
0.5506003 \\
0.23110-01\end{array}$ & $\begin{array}{l}0.22410-02 \\
0.3988003 \\
0.5859004 \\
0.2385004 \\
0.1281004 \\
0.5564003 \\
0.24050-01\end{array}$ \\
\hline 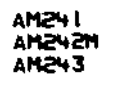 & $\begin{array}{l}0.1111003 \\
0.7269000 \\
0.1090003\end{array}$ & $\begin{array}{ll}0.11650 & 03 \\
0.83600 & 00 \\
0.14050 & 03\end{array}$ \\
\hline $\begin{array}{l}\text { CME42 } \\
\text { CME43 } \\
\text { CME44 } \\
\text { CME45 } \\
\text { CME46 } \\
\text { CME47 } \\
\text { CME48 }\end{array}$ & $\begin{array}{l}0.3367001 \\
0.3456000 \\
0.3319002 \\
0.1910001 \\
0.1941000 \\
0.19340-02 \\
0.84340-04\end{array}$ & $\begin{array}{ll}0.45360 & 01 \\
0.68250 & 00 \\
0.10950 & 03 \\
0.10140 & 02 \\
0.38300 & 01 \\
0.97990-01 \\
0.11510-01\end{array}$ \\
\hline ak249 & $0.47250-06$ & $0.98670-04$ \\
\hline $\begin{array}{l}\text { CF } 249 \\
\text { CF } 250 \\
\text { CF } 251 \\
\text { CF } 252\end{array}$ & $\begin{array}{l}0.72000-05 \\
0.28940-06 \\
0.10700-06 \\
0.39160-07\end{array}$ & $\begin{array}{l}0.16720-03 \\
0.69760-04 \\
0.43580-04 \\
0.35840-04\end{array}$ \\
\hline $\begin{array}{l}\text { SUM U } \\
\text { SUM PU } \\
\text { SUM ACT } \\
\text { SUM ALL. }\end{array}$ & 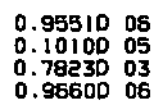 & $\begin{array}{ll}0.95440 & 05 \\
0.10480 & 05 \\
0.11340 & 04 \\
0.96600 & 06\end{array}$ \\
\hline
\end{tabular}

ENDING CONTENTS, O/MTM

\begin{tabular}{|c|c|c|c|}
\hline YCLE 2 & CYCLE 3 & ECrCLE 4 & RECYCLE 5 \\
\hline $\begin{array}{l}0.16850-02 \\
0.10210-03 \\
0.1596003 \\
0.8275004 \\
0.39930 \\
0.9417006\end{array}$ & $\begin{array}{l}0.18350-02 \\
0.11300-03 \\
0.1603003 \\
0.8300004 \\
0.3993004 \\
0.9415006\end{array}$ & $\begin{array}{l}0.18970-02 \\
0.11700-03 \\
0.1609003 \\
0.8313004 \\
0.3985004 \\
0.9414006\end{array}$ & 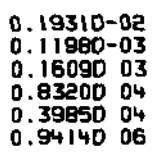 \\
\hline 0.8425003 & 0.8834003 & 0.9039003 & 0.9107003 \\
\hline $\begin{array}{l}0.27400-02 \\
0.4768003 \\
0.58980 \\
0.23970 \\
0.24 \\
0.1288004 \\
0.5555003 \\
0.23970-01\end{array}$ & $\begin{array}{l}0.29580-02 \\
0.5129003 \\
0.5917004 \\
0.2404004 \\
0.12940 .04 \\
0.5547003 \\
0.23970-01\end{array}$ & $\begin{array}{l}0.30470-02 \\
0.5266003 \\
0.59230 \\
0.24040 \\
0.2404 \\
0.12940 .04 \\
0.55470 .03 \\
0.23970-01\end{array}$ & 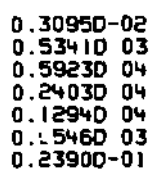 \\
\hline $\begin{array}{r}1178003 \\
.8494000 \\
.1480003\end{array}$ & 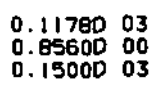 & 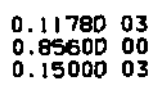 & $\begin{array}{ll}0.11850 & 03 \\
0.85590 & 00 \\
0.15000 & 03\end{array}$ \\
\hline 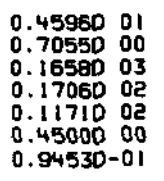 & $\begin{array}{ll}0.46160 & 01 \\
0.71220 & 00 \\
0.19930 & 03 \\
0.191300 & 02 \\
0.22050 & 02 \\
0.220510 & 01 \\
0.10610 & 01 \\
0.32740 & 00\end{array}$ & 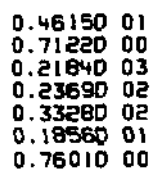 & $\begin{array}{l}0.4615001 \\
0.7121000 \\
0.2287003 \\
0.2499002 \\
0.4459002 \\
0.27320 \text { ol } \\
0.13970 \text { 01 }\end{array}$ \\
\hline $.94530-03$ & $0.35000-02$ & $0.84230-02$ & $0.15890-01$ \\
\hline $\begin{array}{l}16780-02 \\
.99320-03 \\
.52470-03\end{array}$ & $\begin{array}{l}0.63760-02 \\
0.39170-02 \\
0.21440-02 \\
0.36160-02\end{array}$ & $\begin{array}{l}0.15540-01 \\
0.97240-02 \\
0.54170-02 \\
0.10820-01\end{array}$ & $\begin{array}{l}0.29510-01 \\
0.18690-01 \\
0.10550-01 \\
0.23560-01\end{array}$ \\
\hline $\begin{array}{l}.954100 \\
.106200 \\
.131000 \\
.966000\end{array}$ & 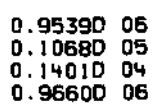 & $\begin{array}{l}0.9539006 \\
0.1070005 \\
0.1456004 \\
0.9660006\end{array}$ & $\begin{array}{lll}0.95380 & 05 \\
0.10710 & 05 \\
0.14860 & 04 \\
0.96600 & 06\end{array}$ \\
\hline
\end{tabular}


TABLE $A \cdot 3$

\section{A11 Actinides From Each LWR U-Assembly Recycled Into New Assembly With Variable U-235 - Case 1.2}

ENDING CONTENTS, G/MTM

\begin{tabular}{|c|c|c|c|c|c|c|}
\hline & START RECYI & RECYCLE I & RECYCLE 2 & RECYCLE 3 & RECYCLE 4 & RECYCLE 5 \\
\hline $\begin{array}{l}\text { U232 } \\
\text { U233 } \\
\text { U234 } \\
\text { u235 } \\
\text { Ue36 } \\
\text { U238 }\end{array}$ & $\begin{array}{l}0.52390-03 \\
0.19030-04 \\
0.1536003 \\
0.1978005 \\
0.4008004 \\
0.9652006\end{array}$ & $\begin{array}{l}0.22900-02 \\
0.14950-03 \\
0.9052002 \\
0.5314004 \\
0.5726004 \\
0.9386006\end{array}$ & $\begin{array}{l}0.44090-02 \\
0.32300-03 \\
0.7749002 \\
0.9168004 \\
0.7749004 \\
0.92790 \text { 06 }\end{array}$ & $\begin{array}{l}0.65290-02 \\
0.49580-03 \\
0.87770 \text { 02 } \\
0.1104005 \\
0.9614004 \\
0.9199006\end{array}$ & $\begin{array}{l}0.86400-02 \\
0.65100-03 \\
0.1125003 \\
0.1404005 \\
0.1156005 \\
0.9111006\end{array}$ & $\begin{array}{l}0.10700-01 \\
0.82290-03 \\
0.1467003 \\
0.1646005 \\
0.1350005 \\
0.9030006\end{array}$ \\
\hline NP237 & 0.5225003 & 0.1097004 & 0.1591004 & 0.2043004 & 0.2469004 & $0.28800 \quad 04$ \\
\hline $\begin{array}{l}\text { PUe36 } \\
\text { PU238 } \\
\text { PU239 } \\
\text { PU240 } \\
\text { PU241 } \\
\text { PU242 } \\
\text { PU244 }\end{array}$ & $\begin{array}{l}0.10900-02 \\
0.1728003 \\
0.5744004 \\
0.2362004 \\
0.1269004 \\
0.5506003 \\
0.23110-01\end{array}$ & $\begin{array}{l}0.36960-02 \\
0.6995003 \\
0.6549004 \\
0.3442004 \\
0.1941004 \\
0.1618004 \\
0.1467000\end{array}$ & $\begin{array}{l}0.63220-02 \\
0.1303004 \\
0.7769004 \\
0.3974004 \\
0.2366004 \\
0.2297004 \\
0.2976000\end{array}$ & $\begin{array}{ll}0.89150-02 \\
0.19410 & 04 \\
0.86880 & 04 \\
0.42720 & 04 \\
0.26880 & 04 \\
0.27840 & 04 \\
0.45460 & 00\end{array}$ & $\begin{array}{l}0.11450-01 \\
0.2599004 \\
0.9576004 \\
0.4615004 \\
0.2990004 \\
0.3120004 \\
0.6007000\end{array}$ & 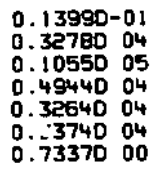 \\
\hline $\begin{array}{l}\text { AMEY I } \\
\text { AMEYZM } \\
\text { AMEZ3 }\end{array}$ & $\begin{array}{l}0.1111003 \\
0.7269000 \\
0.1090003\end{array}$ & $\begin{array}{l}0.1982003 \\
0.1749001 \\
0.5081003\end{array}$ & $\begin{array}{ll}0.27500 & 03 \\
0.31270 & 01 \\
0.65030 & 03\end{array}$ & $\begin{array}{ll}0.33600 & 03 \\
0.43480 & 01 \\
0.10900 & 04\end{array}$ & 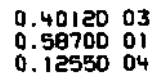 & $\begin{array}{l}0.4649003 \\
0.7475001 \\
0.1371004\end{array}$ \\
\hline $\begin{array}{l}\text { CM242 } \\
\text { CM243 } \\
\text { CM244 } \\
\text { CM245 } \\
\text { CM246 } \\
\text { CM247 } \\
\text { CM248 }\end{array}$ & $\begin{array}{l}0.3367001 \\
0.3458000 \\
0.3319002 \\
0.1810001 \\
0.1941000 \\
0.19340-02 \\
0.84350-04\end{array}$ & 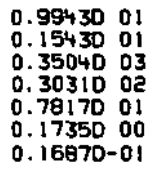 & 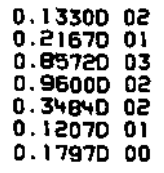 & 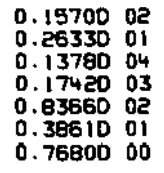 & $\begin{array}{ll}0.17620 & 02 \\
0.29830 & 01 \\
0.18310 & 04 \\
0.25580 & 03 \\
0.14670 & 03 \\
0.92970 & 01 \\
0.20570 & 01\end{array}$ & 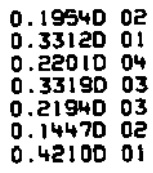 \\
\hline BK249 & $0.47250-06$ & $0.14540-03$ & $0.18990-02$ & $0.91200-02$ & $0.26130-01$ & $0.56300-01$ \\
\hline $\begin{array}{l}\text { CF } 249 \\
\text { CF } 250 \\
\text { CF251 } \\
\text { CF } 252\end{array}$ & $\begin{array}{l}0.72000-06 \\
0.29940-06 \\
0.10700-06 \\
0.39160-07\end{array}$ & $\begin{array}{l}0.24280-03 \\
0.12750-03 \\
0.61170-04 \\
0.45530-04\end{array}$ & $\begin{array}{l}0.34840-02 \\
0.18790-02 \\
0.10490-02 \\
0.95320-13\end{array}$ & $\begin{array}{l}0.17550-01 \\
0.96000-02 \\
0.58700-02 \\
0.59930-02\end{array}$ & $\begin{array}{l}0.52940-01 \\
0.28730-01 \\
0.18930-01 \\
0.19950-01\end{array}$ & $\begin{array}{l}0.1186000 \\
0.63910-01 \\
0.44500-01 \\
0.47520-01\end{array}$ \\
\hline $\begin{array}{l}\text { SUM U } \\
\text { SUM PU } \\
\text { SUM ACT } \\
\text { SUM ALL }\end{array}$ & 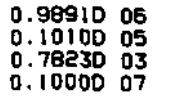 & $\begin{array}{l}0.9497006 \\
0.1425005 \\
0.2205004 \\
0.9662006\end{array}$ & $\begin{array}{l}0.9449006 \\
0.1761005 \\
0.37240 \\
0.94 \\
0.962006\end{array}$ & $\begin{array}{ll}0.94070 & 06 \\
0.20370 & 05 \\
0.51330 & 04 \\
0.96620 & 06\end{array}$ & $\begin{array}{ll}0.93680 & 06 \\
0.23000 & 05 \\
0.63950 & 04 \\
0.96620 & 06\end{array}$ & $\begin{array}{l}0.9331006 \\
0.2541005 \\
0.7518004 \\
0.9650006\end{array}$ \\
\hline
\end{tabular}


TABLE A.4

\section{All Actinides (Except U) From 5 LWR U-Assemblies Recycled Into 1 Assembly of Natural U - Case 1.3}

ENDING CONTENTS, O/MTM

\begin{tabular}{|c|c|c|c|c|c|c|}
\hline & & & & & & \\
\hline & START RECY 1 & RECYCLE I & RECYCLE 2 & RECYCLE 3 & RECYCLE 4 & RECYCLE 3 \\
\hline $\begin{array}{l}\text { U232 } \\
\text { U233 } \\
\text { U234 } \\
\text { U235 } \\
\text { U236 } \\
\text { Ue38 }\end{array}$ & $\begin{array}{l}0.0 \\
0.0 \\
0.0 \\
0.1323004 \\
0.0 \\
0.18780 \quad 06\end{array}$ & $\begin{array}{l}0.15220-02 \\
0.11490-03 \\
0.8914001 \\
0.6940003 \\
0.1326003 \\
0.1833006\end{array}$ & $\begin{array}{l}0.31460-02 \\
0.23910-03 \\
0.2226002 \\
0.1189003 \\
0.1072003 \\
0.1746006\end{array}$ & $\begin{array}{l}0.45810-02 \\
0.34420-03 \\
0.3758002 \\
0.8503003 \\
0.9244002 \\
0.1666006\end{array}$ & $\begin{array}{l}0.59290-02 \\
0.43340-03 \\
0.5445002 \\
0.8517003 \\
0.8174002 \\
0.1589006\end{array}$ & $\begin{array}{l}0.69400-02 \\
0.50740-03 \\
0.71730 \text { 02 } \\
0.83800 \text { 03 } \\
0.73370 \text { 02 } \\
0.15150 \text { 06 }\end{array}$ \\
\hline NP237 & 0.5225003 & 0.3223003 & 0.5578003 & 0.7488003 & 0.9148003 & 0.1063004 \\
\hline $\begin{array}{l}\text { PU236 } \\
\text { PU236 } \\
\text { PU239 } \\
\text { PU240 } \\
\text { PU241 } \\
\text { PU242 } \\
\text { PU244 }\end{array}$ & $\begin{array}{l}0.10900-02 \\
0.1728003 \\
0.5744004 \\
0.2362004 \\
0.1269004 \\
0.5506003 \\
0.23110-01\end{array}$ & $\begin{array}{l}0.19610-02 \\
0.4279003 \\
0.3425004 \\
0.2252004 \\
0.1302004 \\
0.8160003 \\
0.61850-01\end{array}$ & $\begin{array}{l}0.38330-02 \\
0.9604003 \\
0.6624004 \\
0.4262004 \\
0.2326004 \\
0.1551004 \\
0.1061000\end{array}$ & $\begin{array}{l}0.54170-02 \\
0.1542004 \\
0.9658004 \\
0.6206004 \\
0.3106004 \\
0.2238004 \\
0.1687000\end{array}$ & $\begin{array}{l}0.68020-02 \\
0.2148004 \\
0.1256005 \\
0.8160004 \\
0.3722004 \\
0.2894004 \\
0.2277000\end{array}$ & 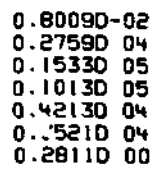 \\
\hline $\begin{array}{l}\text { AMPUI } \\
\text { AMPUEM } \\
\text { AMP43 }\end{array}$ & 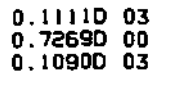 & 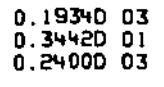 & 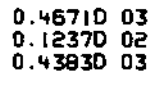 & 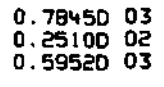 & $\begin{array}{l}0.1137004 \\
0.4032002 \\
0.7296003\end{array}$ & 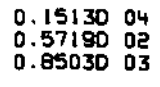 \\
\hline $\begin{array}{l}\text { CM242 } \\
\text { CMP43 } \\
\text { CM244 } \\
\text { CMP45 } \\
\text { CM246 } \\
\text { CM247 } \\
\text { CME48 }\end{array}$ & $\begin{array}{l}0.3367001 \\
0.3456000 \\
0.3319002 \\
0.1910001 \\
0.1941000 \\
0.19340-02 \\
0.84340-04\end{array}$ & 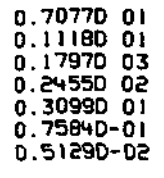 & $\begin{array}{l}0.1186002 \\
0.1978001 \\
0.4163003 \\
0.7845002 \\
0.1002002 \\
0.4108000 \\
0.33940-01\end{array}$ & 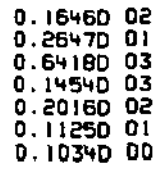 & $\begin{array}{lll}0.19690 & 02 \\
0.31540 & 01 \\
0.84340 & 03 \\
0.21530 & 03 \\
0.232540 & 02 \\
0.322630 & 01 \\
0.22630 \\
0.22230 & 00\end{array}$ & $\begin{array}{ll}0.22630 & 02 \\
0.35380 & 01 \\
0.10180 & 04 \\
0.28250 & 03 \\
0.46350 & 02 \\
0.38260 & 01 \\
0.39360 & 00\end{array}$ \\
\hline BK249 & $0.47250-06$ & $0.51980-04$ & $0.43830-03$ & $0.14810-02$ & $0.33600-02$ & $0.60760-02$ \\
\hline $\begin{array}{l}\text { CF249 } \\
\text { CF250 } \\
\text { CF } 251 \\
\text { CF } 252\end{array}$ & $\begin{array}{l}0.72000-06 \\
0.28940-06 \\
0.10700-06 \\
0.39160-07\end{array}$ & $\begin{array}{l}0.95450-04 \\
0.40070-04 \\
0.22490-04 \\
0.79540-05\end{array}$ & $\begin{array}{l}0.92740-03 \\
0.42320-03 \\
0.27890-03 \\
0.79270-04\end{array}$ & $\begin{array}{l}0.34290-02 \\
0.17200-02 \\
0.12190-02 \\
0.30310-03\end{array}$ & $\begin{array}{l}0.62420-02 \\
0.45530-02 \\
0.33330-02 \\
0.73240-03\end{array}$ & $\begin{array}{l}0.15500-01 \\
0.94080-02 \\
0.70220-02 \\
0.13600-02\end{array}$ \\
\hline $\begin{array}{l}\text { SUM U } \\
\text { SUM PU } \\
\text { SUM ACT } \\
\text { SUM ALL }\end{array}$ & $\begin{array}{l}0.1891006 \\
0.1010005 \\
0.78230 \\
0.20000 \\
06\end{array}$ & 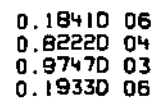 & 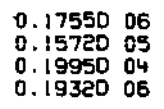 & $\begin{array}{ll}0.16750 & 06 \\
0.22750 & 05 \\
0.29810 & 04 \\
0.19330 & 06\end{array}$ & 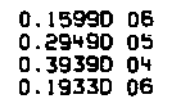 & 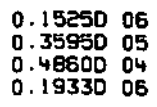 \\
\hline
\end{tabular}


TABLE A.5

\section{Waste Actinides From 20 LWR UnFuel Rods Recycled Into 1 Target Rod of Depleted U - Case 1.4}

\begin{tabular}{|c|c|c|c|c|c|c|}
\hline & & & & NTS. & & \\
\hline & START RECYI & RECYCLE 1 & RECYCLE 2 & RECYCLE 3 & RECYCLE 4 & RECYCLE 5 \\
\hline $\begin{array}{l}\text { U234 } \\
\text { U235 } \\
\text { Ue36 } \\
\text { U238 }\end{array}$ & $\begin{array}{l}0.0 \\
0.9943002 \\
0.0 \\
0.4912005\end{array}$ & $\begin{array}{l}0.44570 \quad 01 \\
0.2331002 \\
0.1234002 \\
0.4786005\end{array}$ & $\begin{array}{l}0.1166002 \\
0.8572001 \\
0.1269002 \\
0.4676005\end{array}$ & $\begin{array}{l}0.19200 \\
0.72000 \\
0.71 \\
0.1131002 \\
0.46070 \quad 05\end{array}$ & $\begin{array}{l}0.2571002 \\
0.9257001 \\
0.1063002 \\
0.45560 \\
05\end{array}$ & $\begin{array}{l}0.3086002 \\
0.1200002 \\
0.1029002 \\
0.4517005\end{array}$ \\
\hline 2237 & $0.52250 \quad 03$ & 0.2307003 & $0.34290 \quad 03$ & 0.3977003 & 0.4286003 & 0.4423003 \\
\hline $\begin{array}{l}\text { Pue36 } \\
\text { PU238 } \\
\text { PU239 } \\
\text { PU240 } \\
\text { PU241 } \\
\text { PU242 } \\
\text { PU244 }\end{array}$ & $\begin{array}{l}0.0 \\
0.0 \\
0.0 \\
0.0 \\
0.0 \\
0.0 \\
0.0\end{array}$ & $\begin{array}{l}0.10970-02 \\
0.2215003 \\
0.3274003 \\
0.1450003 \\
0.6960002 \\
0.3977002 \\
0.22630-02\end{array}$ & $\begin{array}{l}0.18860-02 \\
0.4039003 \\
0.3922003 \\
0.2359003 \\
0.1121003 \\
0.1097003 \\
0.96000-02\end{array}$ & $\begin{array}{l}0.23650-02 \\
0.5335003 \\
0.4330003 \\
0.2955003 \\
0.1358003 \\
0.1776003 \\
0.20570-01\end{array}$ & $\begin{array}{l}0.26400-02 \\
0.26172003 \\
0.4601003 \\
0.3396003 \\
0.1522003 \\
0.2397003 \\
0.33600-01\end{array}$ & $\begin{array}{l}0.28110-02 \\
0.6737003 \\
0.4780003 \\
0.3737003 \\
0.1642003 \\
0.2959003 \\
0.18000-01\end{array}$ \\
\hline $\begin{array}{l}\text { AMEY } 1 \\
\text { AMPUEM } \\
\text { AME4 } 3\end{array}$ & $\begin{array}{l}0.1111003 \\
0.7269000 \\
0.1090003\end{array}$ & $\begin{array}{l}0.9943001 \\
0.1234000 \\
0.4114002\end{array}$ & $\begin{array}{l}0.1680002 \\
0.21600 \text { 00 } \\
0.76800 \text { oe }\end{array}$ & $\begin{array}{l}0.2057002 \\
0.2709000 \\
0.1066003\end{array}$ & $\begin{array}{l}0.2297002 \\
0.3120000 \\
0.1313003\end{array}$ & $\begin{array}{l}0.2503002 \\
0.3429000 \\
0.1509003\end{array}$ \\
\hline $\begin{array}{l}\text { CM242 } \\
\text { CM243 } \\
\text { CM244 } \\
\text { CM245 } \\
\text { CM246 } \\
\text { CM247 } \\
\text { CM248 }\end{array}$ & $\begin{array}{l}0.3367001 \\
0.3456000 \\
0.3319002 \\
0.1810001 \\
0.1941000 \\
0.19340-02 \\
0.84340-04\end{array}$ & 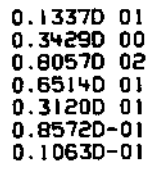 & $\begin{array}{l}0.1851001 \\
0.44570 \\
0.16420 \\
0.13030 \\
0.13202 \\
0.9257001 \\
0.3772000 \\
0.78860-01\end{array}$ & 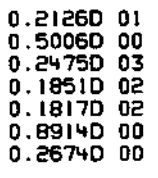 & 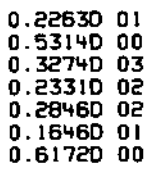 & 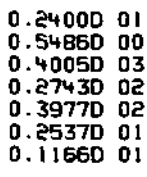 \\
\hline $8 K 249$ & $0.47250-06$ & $0.92570-04$ & $0.82290-03$ & $0.29490-02$ & $0.72000-02$ & $0.14060-01$ \\
\hline $\begin{array}{l}\text { CF } 249 \\
\text { CF250 } \\
\text { CF251 } \\
\text { CF252 }\end{array}$ & $\begin{array}{l}0.72000-06 \\
0.28940-06 \\
0.10700-06 \\
0.39160-07\end{array}$ & $\begin{array}{l}0.15430-03 \\
0.85720-04 \\
0.41140-04 \\
0.35650-04\end{array}$ & $\begin{array}{l}0.14740-02 \\
0.85720-03 \\
0.44570-03 \\
0.58290-03\end{array}$ & $\begin{array}{l}0.54860-02 \\
0.32920-02 \\
0.18510-02 \\
0.29490-02\end{array}$ & $\begin{array}{l}0.13370-01 \\
0.82290-02 \\
0.48000-02 \\
0.85720-02\end{array}$ & $\begin{array}{l}0.26400-01 \\
0.16460-01 \\
0.36000-02 \\
0.18060-01\end{array}$ \\
\hline $\begin{array}{l}\text { SUM U } \\
\text { SUM PU } \\
\text { SUM ACT } \\
\text { SUM ALL }\end{array}$ & 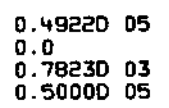 & 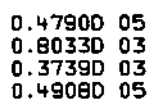 & 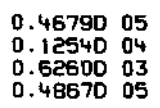 & 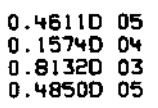 & 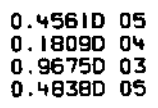 & 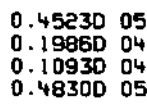 \\
\hline
\end{tabular}


TABLE A. 6

Waste Actinides From 100 LWR U-Fuel Rods Recycled Into 1 Target Rod of Zirconium - Case 2.1

ENDING CONTENTS, G/MTM

\begin{tabular}{|c|c|c|c|c|c|}
\hline START RECYI & RECYCLE I & RECYCLE 2 & RECYCLE 3 & RECYCLE 4 & RECYCLE 5 \\
\hline $\begin{array}{l}0.0 \\
0.0 \\
0.0 \\
0.0 \\
0.0 \\
0.0\end{array}$ & $\begin{array}{l}0.82290-03 \\
0.59080-04 \\
0.4183001 \\
0.4855000 \\
0.37990-01 \\
0.28250-04\end{array}$ & $\begin{array}{l}0.20160-02 \\
0.21570-03 \\
0.1145002 \\
0.2537001 \\
0.3504000 \\
0.47320-03\end{array}$ & $\begin{array}{l}0.31820-02 \\
0.40870-03 \\
0.2009002 \\
0.58080 \text { ol } \\
0.11040 \text { 01 } \\
0.21120-02\end{array}$ & $\begin{array}{l}0.41030-02 \\
0.59110-03 \\
0.2942002 \\
0.9737001 \\
0.2304001 \\
0.56780-02\end{array}$ & $\begin{array}{l}0.50060-02 \\
0.74740-03 \\
0.3895002 \\
0.1406002 \\
0.3881001 \\
0.11590-01\end{array}$ \\
\hline $0.52250 \quad 03$ & $0.24900 \quad 03$ & 0.3977003 & 0.4965003 & $0.56640 \quad 03$ & 0.617800 \\
\hline $\begin{array}{l}0.0 \\
0.0 \\
0.0 \\
0.0 \\
0.0 \\
0.0 \\
0.0\end{array}$ & $\begin{array}{l}0.11860-02 \\
0.2141003 \\
0.3840002 \\
0.1714002 \\
0.81600 \text { 01 } \\
0.1241002 \\
0.99430-03\end{array}$ & $\begin{array}{l}0.23110-02 \\
0.4048003 \\
0.7399002 \\
0.4430002 \\
0.2009002 \\
0.2853002 \\
0.28940-02\end{array}$ & $\begin{array}{l}0.32370-02 \\
0.5678003 \\
0.1038003 \\
0.7564002 \\
0.3209002 \\
0.4704002 \\
0.54650-02\end{array}$ & $\begin{array}{l}0.39770-02 \\
0.7077003 \\
0.1291003 \\
0.1072003 \\
0.4341002 \\
0.6713002 \\
0.83030-02\end{array}$ & $\begin{array}{l}0.45740-02 \\
0.8284003 \\
0.1509003 \\
0.1371003 \\
0.5383002 \\
0.4846002 \\
0.111860-01\end{array}$ \\
\hline $\begin{array}{l}0.1111003 \\
0.7269000 \\
0.1090003\end{array}$ & 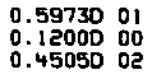 & 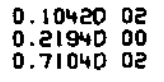 & $\begin{array}{ll}0.14670 & 02 \\
0.32300 & 00 \\
0.89530 & 02\end{array}$ & $\begin{array}{l}0.1872002 \\
0.4258000 \\
0.1014003\end{array}$ & $\begin{array}{ll}0.22490 & 02 \\
0.52660 & 00 \\
0.111180 & 03\end{array}$ \\
\hline $\begin{array}{l}0.33670 \text { 01 } \\
0.34560 \text { o0 } \\
0.3319002 \\
0.1810001 \\
0.1941000 \\
0.19340-02 \\
0.84340-04\end{array}$ & $\begin{array}{l}0.13710 \text { 01 } \\
0.36760 \text { 00 } \\
0.77630 \text { 02 } \\
0.43340 \text { ol } \\
0.21190 \text { ol } \\
0.63360-0.1 \\
0.85030-02\end{array}$ & 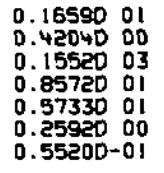 & $\begin{array}{l}0.1872001 \\
0.4519000 \\
0.22440003 \\
0.1269002 \\
0.1022002 \\
0.5856000 \\
0.1697000\end{array}$ & $\begin{array}{l}0.2050001 \\
0.47590 \\
0.400 \\
0.2840003 \\
0.1646002 \\
0.1529002 \\
0.10150 \text { 01 } \\
0.36480 \text { 00 }\end{array}$ & $\begin{array}{ll}0.22080 & 01 \\
0.497200 & 00 \\
0.33460 & 03 \\
0.19890 & 02 \\
0.20540 & 02 \\
0.15290 & 01 \\
0.64530 & 00\end{array}$ \\
\hline $0.47250-06$ & $0.75430-04$ & $0.61720-03$ & $0.21260-02$ & $0.49510-02$ & $0.92570-0$ \\
\hline $\begin{array}{l}0.72000-06 \\
0.2994 D-06 \\
0.10700-06 \\
0.3916 D-07\end{array}$ & $\begin{array}{l}0.12960-03 \\
0.72000-04 \\
0.35110-04 \\
0.30450-04\end{array}$ & $\begin{array}{l}0.11310-02 \\
0.64730-03 \\
0.37240-03 \\
0.41760-03\end{array}$ & $\begin{array}{l}0.40390-02 \\
0.23450-02 \\
0.14810-02 \\
0.18580-02\end{array}$ & $\begin{array}{l}0.96690-02 \\
0.56440-02 \\
0.39060-02 \\
0.50330-02\end{array}$ & $\begin{array}{l}0.18310-01 \\
0.10770-01 \\
0.76120-02 \\
0.10290-01\end{array}$ \\
\hline $\begin{array}{l}0.0 \\
0.0 \\
0.7923003 \\
0.7923003\end{array}$ & $\begin{array}{ll}0.47070 & 01 \\
0.29020 & 03 \\
0.38620 & 03 \\
0.68110 & 03\end{array}$ & 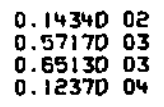 & $\begin{array}{l}0.2701002 \\
0.8264003 \\
0.6504003 \\
0.1704004\end{array}$ & 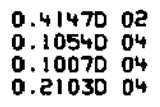 & $\begin{array}{ll}0.56910 & 02 \\
0.12590 & 04 \\
0.11330 & 04 \\
0.24480 & 04\end{array}$ \\
\hline
\end{tabular}


TABLE A.7

Waste Actinides From 50 LWR U-Fuel Rods Recycled Into 1 Target Rod of Zirconium - Case 2.2

ENDING CONTENTS, G/MTH

START RECYI

$\begin{array}{ll}\text { u232 } & 0.0 \\ \text { u233 } & 0.0 \\ \text { u234 } & 0.0 \\ \text { u235 } & 0.0 \\ \text { u236 } & 0.0 \\ \text { v238 } & 0.0\end{array}$

NP237

Puट36

Pu238

Pue39

PUeY

PUट4 1

Pue44

AM24 1

AMZ4 $2 M$

CME42

$\mathrm{CMC}_{4} 3$

СM244

CM245

CMF46

$\mathrm{CM}_{4} 47$
$\mathrm{CM}_{4} \mathrm{C}$

Bर249

CF249

CF25

CF251

SuM $u$

SUM PU

SUM ACT
SUM ALL
0.5225003

0.0

0.0

0.0

0.0

0.0

0.1111003

0.7269000

o. 3367001

0. 3456000

0.33190 02

0.1810001

0.1941000

$0.19340-02$
$0.84340-04$

0.47250-06

0.72000-06

$0.28940-06$

$0.10700-06$
$0.39160-07$

0.0

$\begin{array}{ll}0.0 & \\ 0.78230 & 03\end{array}$

0.7923003

RECYCLE 1

$0.72690-03$

$0.52120-04$

0.423800

$0.50470 \mathrm{DO}$
$0.43750-01$

$0.34970-04$

D. 2304003

0.10290-02

0.5115003

0.41010 0

0.17970 oe

0.990200

0.13030 02

0.4485001

$0.80640-01$

0.4018002

0. 1214001

0.3456000

0.48000 02

0.48000 o1

0.2605001

$0.72820-01$
$0.98880-02$

0.81740-04

$0.13850-03$
$0.79130-04$

$0.79130-04$

$0.36620-04$
$0.35520-04$

0.4787001

0.2934003

0.3637003

0.6619003
RECYCLE 2

$0.16460-02$ $0.17830-03$ 0.1104002 0.24550 ol 0.393500 $0.58560-03$

0.3497003

0. 16380-02

0.3811003

$0.76390 \mathrm{DE}$

0.43200 02

0.231800

0.31680 02

0.720000

0.1271000

0.1426001

0.3909000

0.1566003

0.896900

0.731000

0.68710-01

0.69260-03

0. 12360-02

$0.74470-03$

$0.74470-03$

$0.53490-13$

0. 13990 02 0.5556003

0.5943003

0.1164004
2.600-05 $0.31540-03$ 0.1824002 0.5200001 0.12060 01 $0.26190-02$

0.4169003

o. 24000-02 0.5074003 0.1026003

$0.70080 \mathrm{0Z}$

0.34 B4D De

0.53080 02

0.957300 0.1701000

0.1591001 0.4197000 0.2251003 0.12510 oe 0.13260 O2 0.6940000 0.2181000

0. $24140-02$

$0.44440-02$ $0.27150-02$ $0.15360-02$

0.2473002 0.7680003 0.7579003 0.1551004
RECYCLE 4

$0.30170-02$ $0.43890-03$ 0.2496002 0.93380 01 0.24550 01

0.4571003

. $27840-02$ $0.6004 D 03$ 0.1216003 0.9491002

0.44850 02

0.75700 de $0.11630-0$.

0.1159002 0.2071000 0.89560 02

0.1728001 0.4416000 0.2844003 0.15500 d 02 0.19990 0 $0.12040 \mathrm{DI}$ 0.4800000

0.56640-02

0.10540-01 $0.65560-02$ $0.38540-02$ $0.69530-02$

0.3575002 0.3576002 0.93750 03 $0.1855 \mathrm{D}$ 04
RECYCLE 5

0. 34290-02 $0.52120-03$ 0.30860 02 0.11260 02 0.40050 01 0.4823003 $0.30170-02$ 0.6691003 0.1356003 0.1166003 0.5321002 0. 16470 02

0.1328002 0.2386000 0.9957002

0.18240 ol 0.4594000 0.3357003 0.18100 oe 0.2689002 D. 17970 01 0.8626000

0. 10560-01

0. 20160-01 $0.12430-01$ $0.75290-02$ $0.14540-01$

0.4614002 0.1073004 0.98120
0.21000 
TABLE A. 8

Waste Actinides From 50 LWR U-Fuel Rods Irradiated for 10 Consecutive Fuel Cycles - Case 2.3

ENDINO CONTENTS, O/MTM

\begin{tabular}{|c|c|c|c|c|c|c|}
\hline $\begin{array}{l}\text { U232 } \\
\text { ue33 } \\
\text { u234 } \\
\text { U235 } \\
\text { u236 } \\
\text { Ue38 }\end{array}$ & $\begin{array}{l}0.0 \\
0.0 \\
0.0 \\
0.0 \\
0.0 \\
0.0\end{array}$ & $\begin{array}{l}0.45120-03 \\
0.52120-04 \\
0.2565001 \\
0.5047000 \\
0.43890-01 \\
0.34970-04\end{array}$ & $\begin{array}{l}0.58640-03 \\
0.10330-03 \\
0.4471001 \\
0.1481001 \\
0.2990000 \\
0.51570-03\end{array}$ & $\begin{array}{l}0.42520-03 \\
0.88870-04 \\
0.4293001 \\
0.1810001 \\
0.6761000 \\
0.19470-02\end{array}$ & $\begin{array}{l}0.24270-03 \\
0.55540-04 \\
0.3237001 \\
0.1550001 \\
0.9906000 \\
0.41970-02\end{array}$ & $\begin{array}{l}0.12290-03 \\
0.29620-04 \\
0.2139001 \\
0.1112001 \\
0.1125001 \\
0.67340-02\end{array}$ \\
\hline NP237 & $0.52250 \quad 03$ & 0.2304003 & $0.97920 \quad 02$ & 0.4060002 & 0.1673002 & 0.6926001 \\
\hline $\begin{array}{l}\text { PU236 } \\
\text { PU238 } \\
\text { PUE39 } \\
\text { PU240 } \\
\text { PU24 } \\
\text { PU24 } \\
\text { PU244 }\end{array}$ & $\begin{array}{l}0.0 \\
0.0 \\
0.0 \\
0.0 \\
0.0 \\
0.0 \\
0.0\end{array}$ & $\begin{array}{l}0.13070-02 \\
0.2001003 \\
0.4101002 \\
0.1481002 \\
0.1044002 \\
0.1304002 \\
0.11520-02\end{array}$ & $\begin{array}{l}0.79130-03 \\
0.1552003 \\
0.3648002 \\
0.1989002 \\
0.1632002 \\
0.1989002 \\
0.28250-02\end{array}$ & $\begin{array}{l}0.36340-03 \\
0.87090002 \\
0.2181002 \\
0.1259002 \\
0.1248002 \\
0.2359002 \\
0.48410-02\end{array}$ & $\begin{array}{l}0.15090-03 \\
0.4279000 \\
0.1104002 \\
0.6226001 \\
0.7200001 \\
0.2085002 \\
0.67060-02\end{array}$ & $\begin{array}{l}0.51170-04 \\
0.19610002 \\
0.51290001 \\
0.30720001 \\
0.3040001 \\
0.522002 \\
0.80230-02\end{array}$ \\
\hline $\begin{array}{l}\text { AME4 } 1 \\
\text { AME2 } 2 M \\
\text { AMZ4 } 3\end{array}$ & $\begin{array}{l}0.1111003 \\
0.7269000 \\
0.1090003\end{array}$ & 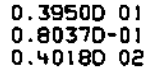 & $\begin{array}{l}0.7625000 \\
0.13690-01 \\
0.1624002\end{array}$ & $\begin{array}{l}0.5692000 \\
0.10040-01 \\
0.1362002\end{array}$ & $\begin{array}{l}0.34290 \quad 00 \\
0.59930-02 \\
0.12210 \text { 02 }\end{array}$ & $\begin{array}{l}0.1824000 \\
0.31680-02 \\
0.1018002\end{array}$ \\
\hline $\begin{array}{l}\text { CM242 } \\
\text { CM243 } \\
\text { CM244 } \\
\text { CM245 } \\
\text { CM246 } \\
\text { CM247 } \\
\text { CM248 }\end{array}$ & $\begin{array}{l}0.3367001 \\
0.3456000 \\
0.3319002 \\
0.1810001 \\
0.1941000 \\
0.19340-02 \\
0.84340-04\end{array}$ & $\begin{array}{l}0.5719001 \\
0.3538000 \\
0.8294002 \\
0.4786001 \\
0.2606001 \\
0.72920-01 \\
0.98750-02\end{array}$ & $\begin{array}{l}0.5856000 \\
0.3456 D-01 \\
0.8092 D 02 \\
0.4951001 \\
0.5788001 \\
0.2482000 \\
0.62950-01\end{array}$ & $\begin{array}{ll}0.38130 & 00 \\
0.14400-01 \\
0.68440 & 02 \\
0.42100 & 01 \\
0.85300 & 01 \\
0.45260 & 00 \\
0.17690 & 00\end{array}$ & $\begin{array}{l}0.2495000 \\
0.96550-02 \\
0.5746002 \\
0.3511001 \\
0.1064002 \\
0.6309000 \\
0.3442000\end{array}$ & $\begin{array}{l}0.1385000 \\
0.55270-02 \\
0.4828002 \\
0.2975001 \\
0.1221002 \\
0.7708000 \\
0.5458000\end{array}$ \\
\hline BK249 & $0.47250-05$ & $0.1824 D-03$ & $0.13340-02$ & $0.38810-02$ & $0.75980-02$ & $0.12060-01$ \\
\hline $\begin{array}{l}\text { CF } 249 \\
\text { CF } 250 \\
\text { CF } 251 \\
\text { CF } 252\end{array}$ & $\begin{array}{l}0.72000-06 \\
0.28940-06 \\
0.10700-06 \\
0.39160-07\end{array}$ & $\begin{array}{l}0.36070-04 \\
0.83110-04 \\
0.36480-04 \\
0.47040-04\end{array}$ & $\begin{array}{l}0.30990-03 \\
0.69940-03 \\
0.32920-03 \\
0.71590-13\end{array}$ & $\begin{array}{l}0.94910-03 \\
0.21810-02 \\
0.10290-02 \\
0.31270-02\end{array}$ & $\begin{array}{l}0.18930-02 \\
0.44020-02 \\
0.20710-02 \\
0.79130-02\end{array}$ & $\begin{array}{l}0.30170-02 \\
0.71320-02 \\
0.33330-02 \\
0.14810-01\end{array}$ \\
\hline $\begin{array}{l}\text { SUM U } \\
\text { SUM PU } \\
\text { SUM ACT } \\
\text { SUM ALL }\end{array}$ & $\begin{array}{l}0.0 \\
0.0 \\
0.7823003 \\
0.7823003\end{array}$ & 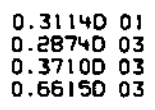 & $\begin{array}{ll}0.62520 & 01 \\
0.24780 & 03 \\
0.20950 & 03 \\
0.46360 & 03\end{array}$ & $\begin{array}{ll}0.67820 & 01 \\
0.15760 & 03 \\
0.13700 & 03 \\
0.30130 & 03\end{array}$ & $\begin{array}{l}0.5771001 \\
0.8811002 \\
0.1022003 \\
0.1960003\end{array}$ & $\begin{array}{ll}0.43830 & 01 \\
0.46880 & 02 \\
0.82250 & 02 \\
0.13350 & 03\end{array}$ \\
\hline
\end{tabular}

RECYCLE 6 RECYCLE 7 RECYCLE 8 RECYCLE 9 RECYCLE 10

\begin{tabular}{|c|c|c|}
\hline $\begin{array}{l}\text { U232 } \\
\text { Ue33 } \\
\text { ve34 } \\
\text { Ue35 } \\
\text { Ue36 } \\
\text { Ue38 }\end{array}$ & $\begin{array}{l}0.58290-04 \\
0.14400-04 \\
0.1304001 \\
0.7159000 \\
0.1123001 \\
0.90380-02\end{array}$ & $\begin{array}{l}0.26610-04 \\
0.67060-05 \\
0.7543000 \\
0.4320000 \\
0.1030001 \\
0.10790-01\end{array}$ \\
\hline NP237 & 0.2952001 & 0.1356001 \\
\hline 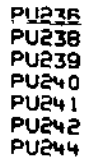 & 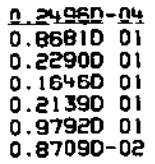 & $\begin{array}{l}\frac{n}{1} \cdot 1056 n-\frac{n}{4} \\
0.38260 \\
0.10120 \\
0.96280 \\
0.12670 \\
0.5925001 \\
0.88870-02\end{array}$ \\
\hline $\begin{array}{l}\text { AMEY1 } \\
\text { AMEY 2M } \\
\text { AME43 }\end{array}$ & $\begin{array}{l}0.99430-01 \\
0.17140-02 \\
0.7596001\end{array}$ & $\begin{array}{l}0.57740-01 \\
0.98880-03 \\
0.5143001\end{array}$ \\
\hline $\begin{array}{l}\text { CMP42 } \\
\text { CME43 } \\
\text { CM244 } \\
\text { CME45 } \\
\text { CME46 } \\
\text { CME47 } \\
\text { CM248 }\end{array}$ & $\begin{array}{l}0.75700-01 \\
0.30310-02 \\
0.395000202 \\
0.2510001 \\
0.1330002 \\
0.8736000 \\
0.7625000\end{array}$ & $\begin{array}{l}0.43750-01 \\
0.17420-02 \\
0.3099002 \\
0.2043001 \\
0.1399002 \\
0.9453000 \\
0.9792000\end{array}$ \\
\hline EK249 & $0.16870-01$ & $0.21670-0$ \\
\hline $\begin{array}{l}\text { CF } 249 \\
\text { CF } 250 \\
\text { CF } 251 \\
\text { CF } 252\end{array}$ & $\begin{array}{l}0.42380-02 \\
0.10120-01 \\
0.47180-02 \\
0.23310-01\end{array}$ & $\begin{array}{l}0.54720-02 \\
0.13120-01 \\
0.61170-02 \\
0.32500-01\end{array}$ \\
\hline $\begin{array}{l}\text { SUM U } \\
\text { SUM PU } \\
\text { SUM ACT } \\
\text { SUM ALL }\end{array}$ & $\begin{array}{ll}0.31520 & 01 \\
0.24560 & 02 \\
0.67750 & 02 \\
0.95460 & 02\end{array}$ & $\begin{array}{l}0.2227001 \\
0.1300002 \\
0.5564002 \\
0.70860 \text { oz }\end{array}$ \\
\hline
\end{tabular}

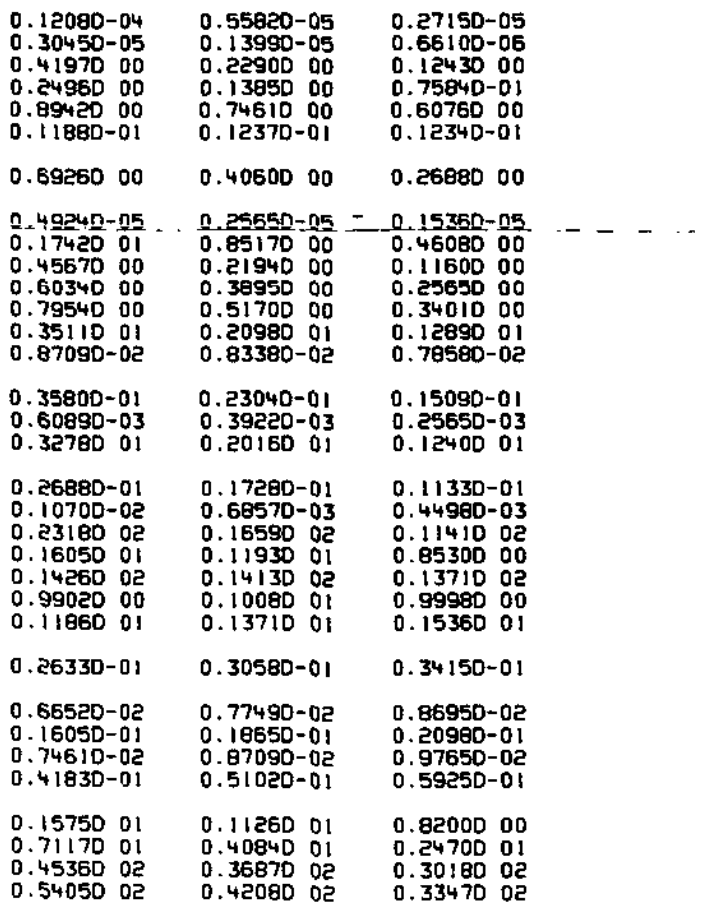




\section{TABLE A.9 \\ Beginning and Ending Actinide Content of Mixed U/Pu Fuel, g/MTM \\ EEGIN END (ONE YEAR DECAY)}

\begin{tabular}{|c|c|c|c|}
\hline $\begin{array}{l}\text { ue34 } \\
\text { ue35 } \\
\text { ve36 } \\
\text { ve38 }\end{array}$ & $\begin{array}{l}0.28500 \\
0.65800 \\
0.0 \\
0.94770\end{array}$ & $\begin{array}{l}03 \\
04 \\
05\end{array}$ & $\begin{array}{l}0.17030 \\
0.30450 \\
0.70650 \\
0.92700\end{array}$ \\
\hline NP237 & 0.0 & & 0.18380 \\
\hline $\begin{array}{l}\text { PU238 } \\
\text { PU239 } \\
\text { PU240 } \\
\text { PuE41 } \\
\text { PUE4? }\end{array}$ & $\begin{array}{l}0.10100 \\
0.22400 \\
0.11600 \\
0.66500 \\
0.37900\end{array}$ & $\begin{array}{l}04 \\
05 \\
05 \\
04 \\
04\end{array}$ & $\begin{array}{l}0.99450 \\
0.10510 \\
0.10380 \\
0.51650 \\
0.54870\end{array}$ \\
\hline $\begin{array}{l}\text { AMEY I } \\
\text { AME4 } \\
\text { AMPY } 3\end{array}$ & $\begin{array}{l}0.0 \\
0.0 \\
0.0\end{array}$ & & $\begin{array}{l}0.65160 \\
0.82310 \\
0.11180\end{array}$ \\
\hline 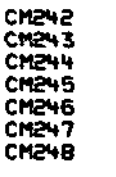 & $\begin{array}{l}0.0 \\
0.0 \\
0.0 \\
0.0 \\
0.0 \\
0.0 \\
0.0\end{array}$ & & $\begin{array}{l}0.28600 \\
0.36350 \\
0.59260 \\
0.53160 \\
0.61730 \\
0.90540 \\
0.44170\end{array}$ \\
\hline $\begin{array}{l}\text { SUM U } \\
\text { SUM PU } \\
\text { SUM ACT } \\
\text { SUM ALL }\end{array}$ & $\begin{array}{l}0.95460 \\
0.45450 \\
0.0 \\
0.10000\end{array}$ & $\begin{array}{l}06 \\
05 \\
07\end{array}$ & $\begin{array}{l}0.93090 \\
0.32540 \\
0.26460 \\
0.96510\end{array}$ \\
\hline
\end{tabular}


TABLE A. 10

Comparison of Waste Actinides Generated in 3 Fuel Types ENDING CONTENTS. O/MTM

SEPARATE ROO

U ASS ' $Y$

U/PU ASS'Y

(ONE YEAR DECAY)

\begin{tabular}{|c|c|c|}
\hline NPE3? & 0.5225003 & 0.4617003 \\
\hline 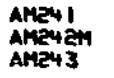 & 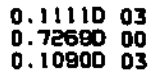 & $\begin{array}{l}0.90390 \text { 0. } \\
0.54290 \text { DO } \\
0.89920 \text { o. }\end{array}$ \\
\hline 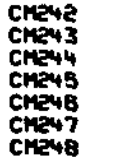 & $\begin{array}{l}0.3367001 \\
0.3456000 \\
0.3319002 \\
0.1810001 \\
0.1941000 \\
0.19340-02 \\
0.84340-04\end{array}$ & 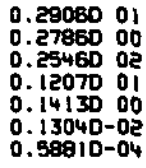 \\
\hline $\begin{array}{l}\text { SUn U } \\
\text { SUN } \text { OU } \\
\text { SUA ACt } \\
\text { SUN ALL }\end{array}$ & $\begin{array}{l}0.0 \\
0.0 \\
0.7023003 \\
0.7923003\end{array}$ & $\begin{array}{l}0.0 \\
0.0 \\
0.6724003 \\
0.6724003\end{array}$ \\
\hline
\end{tabular}

0.1848003

0.6558003

0.82090 01

0.1122004

0.29700 02

0.36620 of

0.5959003

0.53390 02

0.61890 01

$0.90590-01$

$0.44320-02$

0.0

0.0
0.265800

0.2658004 
TABLE A. 11

Waste Actinide Content of Target Assembly in U/Pu Lattice - Case 3.1

ENDING CONTENTS, G/MTM

START RECY1 RECYCLE 1 RECYCLE 2 RECYCLE 3 RECYCLE 4 RECYCLE 5

\begin{tabular}{|c|c|c|c|c|c|c|}
\hline NP237 & 0.3696003 & 0.1031003 & 0.1462003 & 0.1680003 & 0.1810003 & 0.1886003 \\
\hline 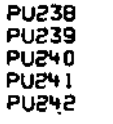 & $\begin{array}{l}0.0 \\
0.0 \\
0.0 \\
0.0 \\
0.0\end{array}$ & $\begin{array}{lll}0.11990 & 03 \\
0.31500 & 02 \\
0.50020 & 02 \\
0.15200 & 02 \\
0.45060 & 02\end{array}$ & 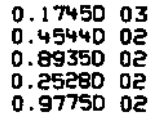 & $\begin{array}{lll}0.20430 & 03 \\
0.53070 & 02 \\
0.12140 & 03 \\
0.32950 & 02 \\
0.14810 & 03\end{array}$ & $\begin{array}{lll}0.22450 & 03 \\
0.58040 & 02 \\
0.14810 & 03 \\
0.39330 & 02 \\
0.19550 & 03\end{array}$ & 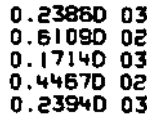 \\
\hline 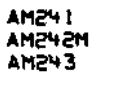 & $\begin{array}{ll}0.27840 & 03 \\
0.30890 & 01 \\
0.43150 & 03\end{array}$ & 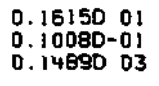 & $\begin{array}{l}0.2829001 \\
0.19170-01 \\
0.2302003\end{array}$ & $\begin{array}{l}0.37610 \text { ol } \\
0.26350-01 \\
0.29180 \text { 03 }\end{array}$ & $\begin{array}{l}0.4544001 \\
0.33140-01 \\
0.3188003\end{array}$ & $\begin{array}{l}0.32690 \text { ol } \\
0.38930-01 \\
0.34850 \text { o3 }\end{array}$ \\
\hline $\begin{array}{l}\text { CM242 } \\
\text { CM243 } \\
\text { CM244 } \\
\text { CM245 } \\
\text { CM246 } \\
\text { CM247 } \\
\text { CM248 }\end{array}$ & $\begin{array}{l}0.1149002 \\
0.1405001 \\
0.2150003 \\
0.18590002 \\
0.2150001 \\
0.31000-01 \\
0.15120-02\end{array}$ & $\begin{array}{l}0.1478001 \\
0.4047000 \\
0.3856003 \\
0.7464001 \\
0.1565002 \\
0.3543000 \\
0.97750-01\end{array}$ & 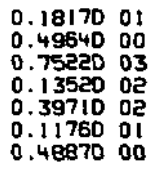 & 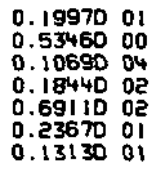 & $\begin{array}{l}0.2176001 \\
0.57660 \text { 00 } \\
0.13290 \text { o4 } \\
0.2245002 \\
0.1016003 \\
0.3849001 \\
0.26580 \text { ol }\end{array}$ & $\begin{array}{ll}0.22990 & 01 \\
0.20330 & 00 \\
0.15580 & 04 \\
0.155740 & 02 \\
0.25740 & 02 \\
0.13590 & 03 \\
0.54980 & 01 \\
0.45440 & 01\end{array}$ \\
\hline BK249 & 0.0 & $0.41240-03$ & $0.23710-02$ & $0.68730-02$ & $0.14700-01$ & $0.26000-01$ \\
\hline $\begin{array}{l}\text { CF249 } \\
\text { CF250 } \\
\text { CF251 } \\
\text { CF252 }\end{array}$ & $\begin{array}{l}0.0 \\
0.0 \\
0.0 \\
0.0\end{array}$ & $\begin{array}{l}0.62620-03 \\
0.53460-03 \\
0.17950-03 \\
0.52690-03\end{array}$ & $\begin{array}{l}0.37080-02 \\
0.32000-02 \\
0.11300-02 \\
0.45060-02\end{array}$ & $\begin{array}{l}0.10960-01 \\
0.94690-02 \\
0.34400-02 \\
0.15880-01\end{array}$ & $\begin{array}{l}0.23600-01 \\
0.20430-01 \\
0.75600-02 \\
0.38070-01\end{array}$ & $\begin{array}{l}0.42000-01 \\
0.36430-01 \\
0.13670-01 \\
0.72550-01\end{array}$ \\
\hline $\begin{array}{l}\text { SUM U } \\
\text { SUM PU } \\
\text { SUM ACT } \\
\text { SUM ALL }\end{array}$ & $\begin{array}{ll}0.0 & \\
0.0 & \\
0.13310 & 04 \\
0.13310 & 04\end{array}$ & $\begin{array}{ll}0.0 & \\
0.26170 & 03 \\
0.66470 & 03 \\
0.92540 & 03\end{array}$ & $\begin{array}{ll}0.0 & \\
0.43230 & 03 \\
0.11890 & 04 \\
0.16210 & 04\end{array}$ & $\begin{array}{ll}0.0 & \\
0.55990 & 03 \\
0.16160 & 04 \\
0.21760 & 04\end{array}$ & $\begin{array}{ll}0.0 & \\
0.65550 & 03 \\
0.19670 & 04 \\
0.26320 & 04\end{array}$ & $\begin{array}{l}0.0 \\
0.7553003 \\
0.2275004 \\
0.3030004\end{array}$ \\
\hline
\end{tabular}


TABLE A, 12

Waste Actinide Content of Target Assembly in U/Pu Lattice - Case 3.2

ENDING CONTENTS, G/HTH

\begin{tabular}{|c|c|c|c|c|c|c|}
\hline & START RECYI & RECYCLE I & RECYCLE 2 & RECYCLE 3 & RECYCLE 4 & RECYCLE 5 \\
\hline NP237 & 0,3696003 & 0.1613003 & 0.2931003 & 0.4047003 & 0.5099003 & 0.5968003 \\
\hline $\begin{array}{l}\text { PUe38 } \\
\text { Pu239 } \\
\text { Pu240 } \\
\text { Puz41 } \\
\text { PuZ42 }\end{array}$ & $\begin{array}{l}0.0 \\
0.0 \\
0.0 \\
0.0 \\
0.0\end{array}$ & 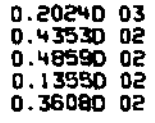 & $\begin{array}{ll}0.36850 & 03 \\
0.73370 & 02 \\
0.10880 & 03 \\
0.33310 & 02 \\
0.75120 & 02\end{array}$ & 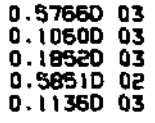 & 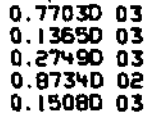 & 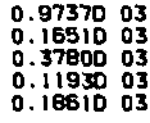 \\
\hline 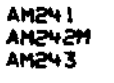 & $\begin{array}{l}0.27840 \text { 03 } \\
0.30990 \text { 01 } \\
0.43150 \text { 03 }\end{array}$ & 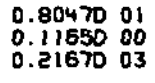 & $\begin{array}{l}0.2701002 \\
0.4716000 \\
0.3856003\end{array}$ & 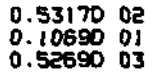 & $\begin{array}{l}0.84670 \text { 02 } \\
0.19190 \text { 01 } \\
0.64910 \text { 03 }\end{array}$ & $\begin{array}{l}0.1212003 \\
0.3055001 \\
0.7579003\end{array}$ \\
\hline $\begin{array}{l}\text { CMz42 } \\
\text { CMZ43 } \\
\text { CM244 } \\
\text { CM245 } \\
\text { CM246 } \\
\text { CMZ247 } \\
\text { CM248 }\end{array}$ & $\begin{array}{l}0.11490 \text { 02 } \\
0.1405001 \\
0.2150003 \\
0.1859002 \\
0.21500 \text { 01 } \\
0.31000-01 \\
0.15120-02\end{array}$ & $\begin{array}{l}0.3351001 \\
0.6267000 \\
0.3503003 \\
0.7990001 \\
0.1040002 \\
0.2931000 \\
0.59510-01\end{array}$ & $\begin{array}{l}0.49830 \text { 01 } \\
0.10790 \text { ol } \\
0.6997003 \\
0.2005002 \\
0.2405002 \\
0.8851000 \\
0.2425000\end{array}$ & 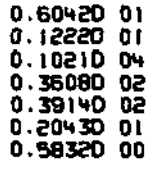 & $\begin{array}{l}0.68060 \text { 01 } \\
0.12890 \text { ol } \\
0.12690 \text { 04 } \\
0.55650 \text { 02 } \\
0.54790 \text { 02 } \\
0.34080 \text { ol } \\
0.10800 \text { 01 }\end{array}$ & $\begin{array}{ll}0.73880 & 01 \\
0.7360 & 01 \\
0.15370 & 04 \\
0.77510 & 02 \\
0.70260 & 02 \\
0.50310 & 01 \\
0.17180 & 01\end{array}$ \\
\hline BK249 & 0.0 & $0.35990-03$ & $0.20010-02$ & $0.60810-02$ & $0.12090-01$ & D. 2EBED-0 \\
\hline $\begin{array}{l}\text { CF } 249 \\
\text { CF } 550 \\
\text { CFES! } \\
\text { CFESE }\end{array}$ & $\begin{array}{l}0.0 \\
0.0 \\
0.0 \\
0.0\end{array}$ & $\begin{array}{l}0.59090-03 \\
0.40280-03 \\
0.16040-03 \\
0.25390-03\end{array}$ & $\begin{array}{l}0.37990-02 \\
0.23590-02 \\
0.11360-02 \\
0.16990-02\end{array}$ & $\begin{array}{l}0.12120-01 \\
0.70450-02 \\
0.39140-02 \\
0.50210-02\end{array}$ & $\begin{array}{l}0.27010-01 \\
0.15370-01 \\
0.95460-02 \\
0.10310-01\end{array}$ & $\begin{array}{l}0.49640-01 \\
0.27970-01 \\
0.18000-01 \\
0.17290-01\end{array}$ \\
\hline $\begin{array}{l}\text { SUM U } \\
\text { SUM PU } \\
\text { SUM ACT } \\
\text { SUM ALL }\end{array}$ & $\begin{array}{l}0.0 \\
0.0 \\
0.1331004 \\
0.13310 \text { 04 }\end{array}$ & $\begin{array}{l}0.0 \\
0.34450 \\
0.7594003 \\
0.1104004\end{array}$ & $\begin{array}{l}0.0 \\
0.6921003 \\
0.1456004 \\
0.2138004\end{array}$ & $\begin{array}{l}0.0 \\
0.10400 \\
0.20920 \\
04 \\
0.3132004\end{array}$ & $\begin{array}{l}0.0 \\
0.1420004 \\
0.2653004 \\
0.4073004\end{array}$ & $\begin{array}{l}0.0 \\
0.1822004 \\
0.3179004 \\
0.5001004\end{array}$ \\
\hline
\end{tabular}


TABLE A.13 Waste Actinides From Th Assembly Enriched in U-233 and U-235
Recycled Into 1 New Assembly - Case 3.3

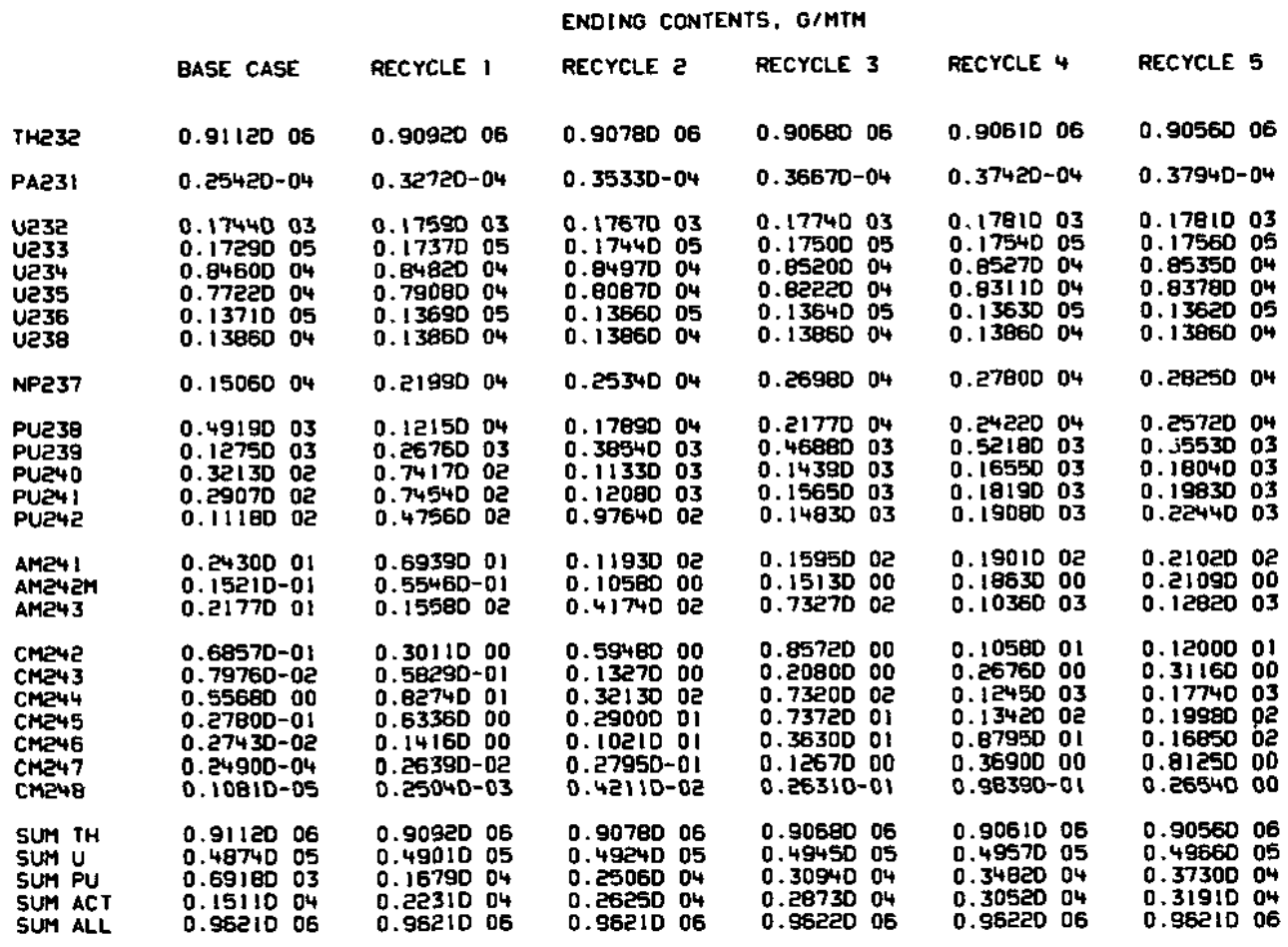


TABLE A. 14

Waste Actinides From 100 LWR U-Fuel Rods Recycled Into Target in SRP Lattice - Case 4.1

ENDINO CONTENTS, O/MTH

\begin{tabular}{|c|c|c|c|c|c|c|}
\hline & \multirow[b]{2}{*}{ START RECYI } & \\
\hline & & RECYCLE I & RECYCLE 2 & RECYCLE 3 & PECYCLE 4 & RECYCLE 5 \\
\hline NPE37 & 0.5225003 & 0.2798003 & 0.4457003 & 0.5527003 & 0.6254003 & 0.8788003 \\
\hline $\begin{array}{l}\text { Pues6 } \\
\text { Pue38 } \\
\text { Pue39 } \\
\text { Pue40 } \\
\text { Pue4 I } \\
\text { Pue42 } \\
\text { Pue44 }\end{array}$ & $\begin{array}{l}0.0 \\
0.0 \\
0.0 \\
0.0 \\
0.0 \\
0.0 \\
0.0\end{array}$ & $\begin{array}{l}0.39770-03 \\
0.2123003 \\
0.3593002 \\
0.1145002 \\
0.47180001 \\
0.1104002 \\
0.18580-02\end{array}$ & $\begin{array}{l}0.80920-03 \\
0.4236003 \\
0.8256002 \\
0.2997002 \\
0.1625002 \\
0.3446002 \\
0.57460-02\end{array}$ & $\begin{array}{l}0.11660-02 \\
0.6041003 \\
0.1234003 \\
0.5013002 \\
0.292800202 \\
0.4066002 \\
0.11520-01\end{array}$ & $\begin{array}{l}0.14540-02 \\
0.7543003 \\
0.1570003 \\
0.7083000 \\
0.4142002 \\
0.5842002 \\
0.18990-01\end{array}$ & $\begin{array}{l}0.16800-02 \\
0.8791003 \\
0.1845003 \\
0.9052002 \\
0.52460 \text { 02 } \\
0.76800 \text { 02 } \\
0.27770-01\end{array}$ \\
\hline $\begin{array}{l}\text { Anz+1 } \\
\text { AME42M } \\
\text { AnE43 }\end{array}$ & $\begin{array}{l}0.1111003 \\
0.7269000 \\
0.1090003\end{array}$ & 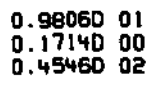 & $\begin{array}{l}0.1323002 \\
0.2304000 \\
0.7042002\end{array}$ & $\begin{array}{l}0.16180 \text { oz } \\
0.29370 \text { 00 } \\
0.87770 \text { oe }\end{array}$ & $\begin{array}{l}0.1899002 \\
0.3333000 \\
0.1015003\end{array}$ & $\begin{array}{l}0.2133002 \\
0.3778000 \\
0.1138003\end{array}$ \\
\hline 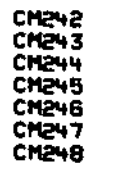 & $\begin{array}{l}0.3367001 \\
0.34560 \\
0.340 \\
0.3319002 \\
0.1810001 \\
0.1941000 \\
0.19340-02 \\
0.84340-04\end{array}$ & $\begin{array}{l}0.72690 \text { 0. } \\
0.13580 \text { 0. } \\
0.80230 \text { o. } \\
0.4732001 \\
0.23860 \text { ol } \\
0.47860-01 \\
0.59730-02\end{array}$ & $\begin{array}{l}0.82290 \text { o1 } \\
0.16660 \text { ol } \\
0.16460 \text { o3 } \\
0.93950 \text { ol } \\
0.68570 \text { o1 } \\
0.21600 \text { o0 } \\
0.44300-01\end{array}$ & 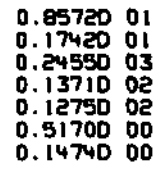 & $\begin{array}{l}0.97770 \text { 01 } \\
0.17900 \text { ol } \\
0.32090 \text { o3 } \\
0.17690 \text { 02 } \\
0.1951002 \\
0.93260 \text { o0 } \\
0.33890 \text { 00 }\end{array}$ & 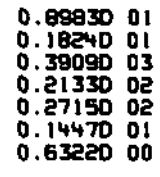 \\
\hline BKe49 & $0.47250-06$ & $0.44370-04$ & $0.41830-03$ & $0.15980-02$ & $0.40050-02$ & $0.79540-02$ \\
\hline $\begin{array}{l}\text { CF } 249 \\
\text { CF } 250 \\
\text { CF } 251 \\
\text { CFase }\end{array}$ & $\begin{array}{l}0.72000-06 \\
0.2994 D-06 \\
0.10700-06 \\
0.39160-07\end{array}$ & $\begin{array}{l}0.61300-04 \\
0.42100-04 \\
0.17900-04 \\
0.19340-04\end{array}$ & $\begin{array}{l}0.59900-03 \\
0.44230-03 \\
0.21120-03 \\
0.32500-03\end{array}$ & $\begin{array}{l}0.23380-02 \\
0.17690-02 \\
0.90520-03 \\
0.17350-02\end{array}$ & $\begin{array}{l}0.59730-02 \\
0.43460-02 \\
0.24410-02 \\
0.54040-02\end{array}$ & $\begin{array}{l}0.12000-01 \\
0.91200-02 \\
0.50950-02 \\
0.12410-01\end{array}$ \\
\hline $\begin{array}{l}\text { sum U } \\
\text { sum PU } \\
\text { SUM ACT } \\
\text { sum ALL }\end{array}$ & 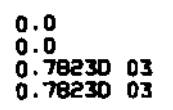 & $\begin{array}{l}0.0 \\
0.2754003 \\
0.4312003 \\
0.7067003\end{array}$ & $\begin{array}{ll}0.0 & \\
0.57680 & 03 \\
0.72060 & 03 \\
0.12970 & 04\end{array}$ & $\begin{array}{l}0.0 \\
0.84760 \text { 03 } \\
0.93990 \text { 03 } \\
0.1788004\end{array}$ & $\begin{array}{l}0.0 \\
0.1082004 \\
0.1116004 \\
0.2188004\end{array}$ & $\begin{array}{l}0.0 \\
0.1293004 \\
0.1269004 \\
0.2548004\end{array}$ \\
\hline
\end{tabular}


TABLE A. 15

Beginning and Ending Contents of Two CANDU FueT Types, g/MTM

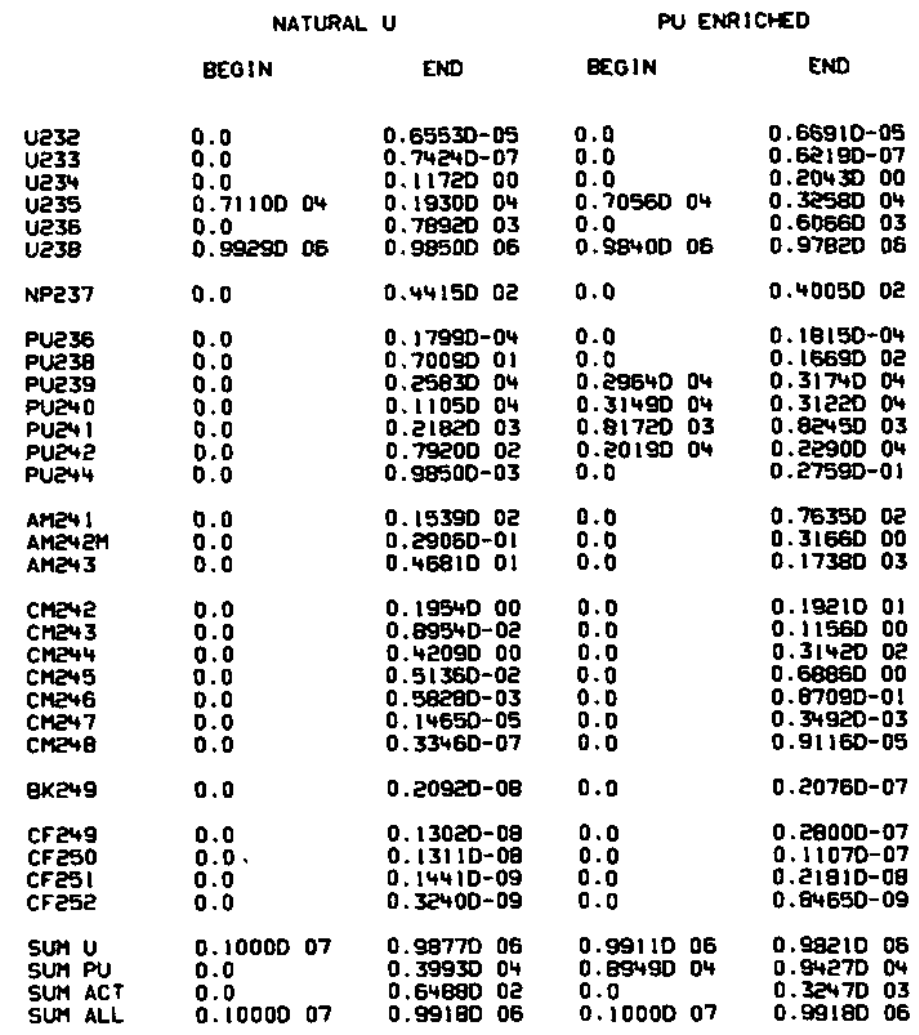


TABLE A.16

Waste Actinides From Each CANDU U/Pu Assembly Recycled Into New Assembly - Case 4.2

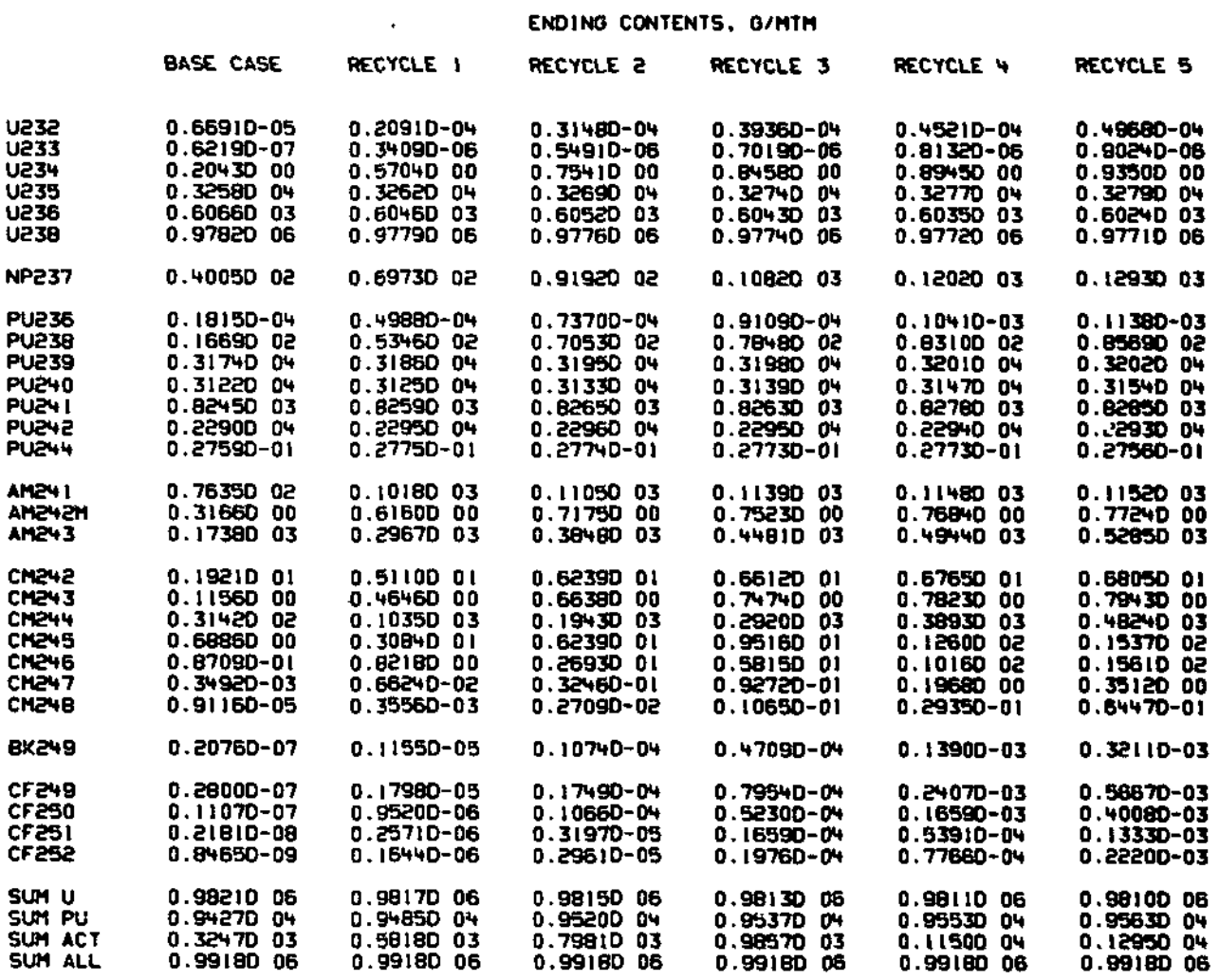




\section{REFERENCES}

1. A. G. Croff, et al. A Preliminary Assessment of Partitioning and Transmutation as a Radioactive Waste Management Concept. ORNL/TM-5808, Oak Ridge National Laboratory, Oak Ridge, TN, (1977).

2. H. C. Honeck. The JOSHUA System. USAEC Report DP-1380, E. I. du Pont de Nemours and Co., Savannah River Laboratory, Aiken, SC (1975).

3. R. W. Benjamin, F. J. McCrosson, V. D. Vandervelde, and

T. C. Gorrell. A Consistent Set of Heavy Actinide Multigroup Cross Sections. USERDA Report DP-1394, E. I. du Pont de Nemours and Co., Savannah River Laboratory, Aiken, SC (1975).

4. "Standard Test Method for Atom Percent Fission in Uranium and Plutonium Fuel (Neodymium-148 Method)." Annual Book of ASTM Standards (Part 45). N118, E321-75, American Society for Testing and Materials, Philadelphia, PA (1976).

5. Arthur A. Bauer, et al. Progress on Evaluating Strength and Ductility of Irradiated Zircaloy During July through September, 1975. USAEC Report BMI-1938, Battelle Columbus Laboratories, Columbus, OH (1975).

6. R. J. Nodvick. Supplementary Report on Evaluation of Mass Spectrometric and Radiochemical Analyses of Yankee Core I Spent Fuel, Including Isotopes of Elements Thorium through Curizon. USAEC Report WCAP 6086, Westinghouse Electric Corporation, Pittsburgh, PA (1969).

7. R. P. Matsen. An Analysis of Yankee-Rowe Burmup Data. USAEC Report BNWL-1122, Batte1le Memorial Institute, Richland, WA (1969).

8. Docket - RESARA - 23. Reference Safety Ana1ysis Report, Volume II, Westinghouse Nuclear Energy Systems, Westinghouse Electric Corporation, Pittsburgh, PA (1973).

9. Assessment of Thorium Fuel Cycles in Pressurized Water Reactors, EPRI NP-359, Electric Power Research Institute, Palo Alto, CF (1977).

10. M. F. Duret, Plutonium Recycle in CANDU-type PHW Heavy Water Reactors, AECL-3910, Atomic Energy of Canada Limited, Chalk River, Ontario (1971). 